Utah State University

DigitalCommons@USU

Reports

Utah Water Research Laboratory

January 1971

\title{
The Effect of Carbon on Algal Growth--Its Relationship to Eutrophication
}

Joel C. Goldman

Donald B. Porcella

Joe E. Middlebrooks

Daniel F. Toerien

Follow this and additional works at: https://digitalcommons.usu.edu/water_rep

Part of the Civil and Environmental Engineering Commons, and the Water Resource Management

Commons

\section{Recommended Citation}

Goldman, Joel C.; Porcella, Donald B.; Middlebrooks, Joe E.; and Toerien, Daniel F., "The Effect of Carbon on Algal Growth--Its Relationship to Eutrophication" (1971). Reports. Paper 462.

https://digitalcommons.usu.edu/water_rep/462

This Report is brought to you for free and open access by the Utah Water Research Laboratory at

DigitalCommons@USU. It has been accepted for inclusion in Reports by an authorized administrator of DigitalCommons@USU. For more information, please contact digitalcommons@usu.edu.

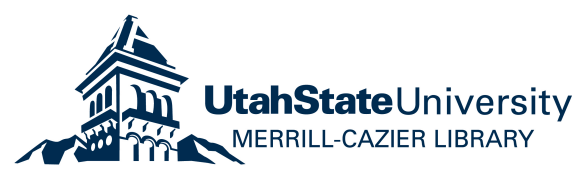




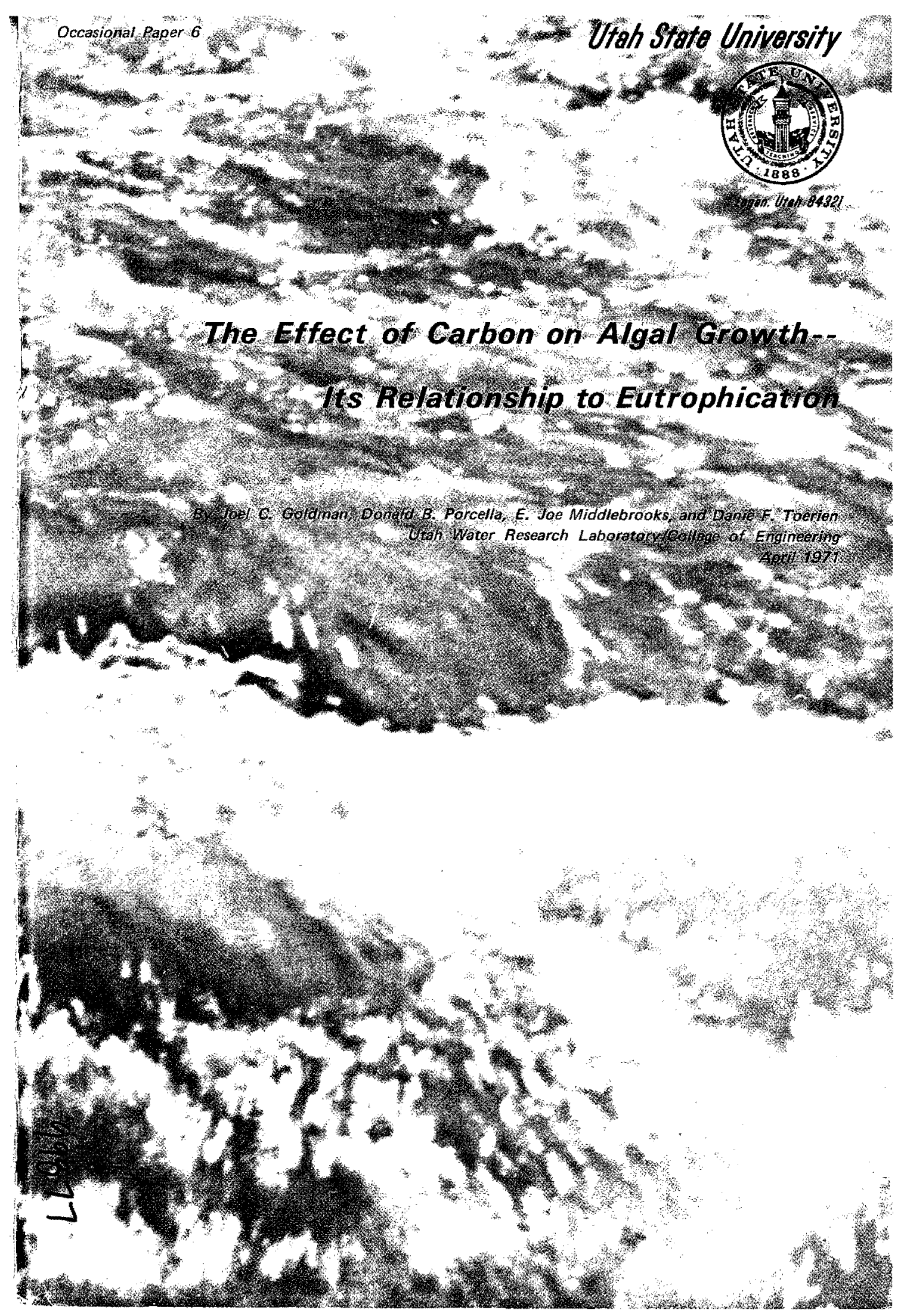


ERRATA

\begin{tabular}{|c|c|c|c|}
\hline Page & Line & Reads & Should Read \\
\hline 10 & 16 & $2\left(4 \mathrm{PO}_{4}=\right)$ & $2\left(\mathrm{HPO}_{4}=\right)$ \\
\hline 14 & Figure Title & Trusse1 (1970) & Trussel1 (1970) \\
\hline 39 & Figure Title & Coree $(1970)$ & Foree $(1970)$ \\
\hline 55 & 23 & antotrophic & autotrophic \\
\hline
\end{tabular}

Table 7. Alkalinity and pH data for various natural water bodies in North America.

\begin{tabular}{|c|c|c|c|c|c|c|c|}
\hline Water Body & $\begin{array}{r}\text { Total } \\
\text { Alkalini } \\
\mathrm{mg} / 1 \text { as } 0 \\
\end{array}$ & $\begin{array}{l}=y \text { Actual } \\
\mathrm{CO}_{3} \mathrm{pH}^{1}\end{array}$ & $\begin{array}{c}\text { Equilibrium } \\
\mathrm{pH} \\
\mathrm{a}_{20} 0^{\circ} \mathrm{c}^{2}\end{array}$ & $\begin{array}{c}\text { Free } \\
\mathrm{CO}_{2} \\
\mathrm{e}_{20} 0^{\circ} \mathrm{c}^{3}\end{array}$ & $\begin{array}{l}\text { Total } \\
\text { Inorganic } \\
\text { Carbon } \\
\text { mg/ } / 1^{4}\end{array}$ & $\begin{array}{l}\text { Reported } \\
\text { Condition of } \\
\text { Water Body }\end{array}$ & Reference \\
\hline \multicolumn{8}{|l|}{ Great Lakes } \\
\hline Erie & 97 & 8.1 & 8.60 & 1.64 & 24.3 & Eutrophic & \multirow{5}{*}{ Benoit (1969) } \\
\hline Ontario & 96 & 8.1 & 8,60 & 1.63 & 25.0 & Eutrophic & \\
\hline Michigan & 113 & 8.0 & 8.65 & 2.39 & 27.1 & \multirow{3}{*}{$\begin{array}{l}\text { Generally } \\
\text { Oligotrophic }\end{array}$} & \\
\hline Huron & 82 & 8.1 & 8.51 & 1.39 & 19.7 & & \\
\hline Superior & 46 & 7.4 & 8.27 & 3.88 & 12.0 & & \\
\hline Lake Tahoe, Calif. & 41 & 7.8 & 8.24 & 1.38 & 10.2 & Oligotrophic. & \multirow{4}{*}{$\begin{array}{l}\text { McGauhey et al. (1968) } \\
\text { Provasoli (1969) } \\
\text { Oglesby (1969) }\end{array}$} \\
\hline Goose Lake, Wis. & 107 & 7.9 & 8.63 & 2.65 & 26.8 & oligotrohpic & \\
\hline Sylvan Lake, Wis. & 110 & 9.1 & 8.64 & 0,17 & 26.4 & Hypereutrophicf & \\
\hline Green Lake, Wash. & 32.6 & 7.7 & 8.17 & 1.29 & 8.2 & Eutrophic & \\
\hline \multirow{6}{*}{$\begin{array}{l}\text { Canadian Lakes } \\
\text { Cree Lake } \\
\text { LaRonge Lake } \\
\text { Waskesiu Lake } \\
\text { Hunter Bay Lake }\end{array}$} & & & & & & \multirow{6}{*}{$\left.\begin{array}{l}\text { Oligotrophic } \\
\text { Mesotrophic } \\
\text { Eutrophic } \\
\text { Oligotrophic- } \\
\text { Mesotrophic } \\
\text { Eutrophic }\end{array}\right\}$} & \multirow{6}{*}{ Rawson (1960) } \\
\hline & $48 \frac{3}{5}$ & 7.26 & 8.27 & 6.02 & 13.4 & & \\
\hline & $122_{5}^{3}$ & $8.2-7.7_{6}^{\circ}$ & 8.69 & $1.63-5.18$ & $29 \cdot 3-30.5$ & & \\
\hline & $154_{5}^{3}$ & $8.2-7.7^{\circ}$ & 8.78 & $2.06-6.53$ & $37.0-38.5$ & & \\
\hline & $97^{3}$ & $7.9-7.5^{\circ}$ & 8.60 & $2.59-6.49$ & $24.3-25.2$ & & \\
\hline & $113^{5}$ & $8.2-7.2^{6}$ & 8.65 & $1.51-14.2$ & $27.1-31.6$ & & \\
\hline
\end{tabular}

1 Data from reference cited

2 Calculated from Equation 10

3 Calculated from Equation 12

4 Calculated using Saunders et a1. (1962) method based on $\mathrm{pH}$ and total alkalinity

5 Based upon Rawson's (1960) assumption that 85 percent of the total dissolved solids was bicarbonate

6 Surface pH - Bottom pH 
Occasional Paper 6

\title{
THE EFFECT OF CARBON ON ALGAL GROWTH-- ITS RELATIONSHIP TO EUTROPHICATION
}

\author{
A Review Paper
}

\section{By}

Joel C. Goldman

Donald B. Porcella

E. Joe Middlebrooks

Danie F. Toerien

Utah Water Research Laboratory

College of Engineering

Utah State University

Logan, Utah 84321

April 1971 
Joel $C$. Gotdman is currently a doctoral candidate in Environmental Health Sciences at the University of California. Berkeley. Before going to Berkeley he attended the University of Minnesota where he received both his bachelors and masters degrees in Civil Engineering. Included in Mr. Goldman's engineering experience are employment with the New York City Board of Water Supply and a sanitary engineering consulting firm in $\mathrm{Min}$ neapolis. More recently he participated in a joint Federal Government-State of California research program to determine the feasibility of removing nitrate-nitrogen from agricultural return waters of the San Joaquin Vallzy in central California by growing and harvesting algae. Since then he has become involved in various problems in aquatic biology, particularly the role that inorganic carbon plays in the eutrophication process.

Donald B. Procella is Assistant Professor of Environmental Biology at Utah State Univerşity where he is involved in water quality research at the Utah Water Research Laboratory. Before coming to USU Dr. Porcella was at the University of California at Berkeley as an assistant research zoologist at the Sanitary Engineering Research Laboratory. He was a Fulbright post graduate fellow at the Norwegian Institute for Water Research at Oslo, Norway, and he was also a research zoologist for the U.S. Public Health Service at the R.A. Taft Sanitary Engineering Center in Cincinnati, Ohio. He received the A.B. and M.A. degrees in $200-$ logy and the Ph.D. degree in Environmental Health Science at the University of California at Berkeley. He is the author or co-author of some 25 publications.

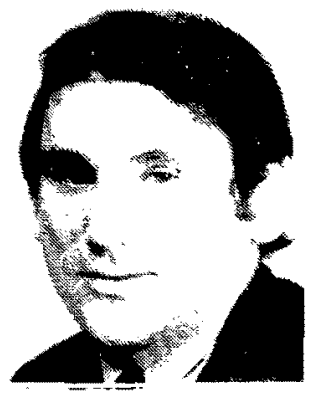

Joel C. Goldman

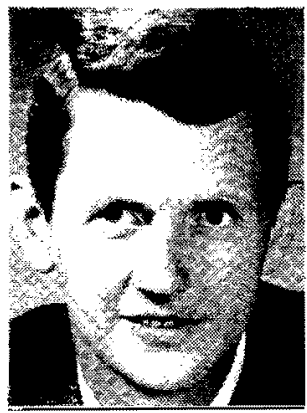

Donald B. Porcella

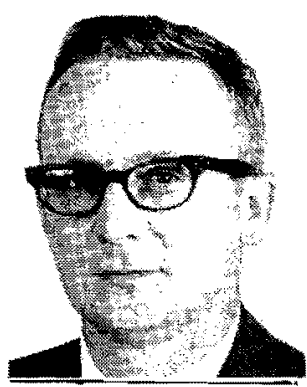

E. Joe Middlebrooks

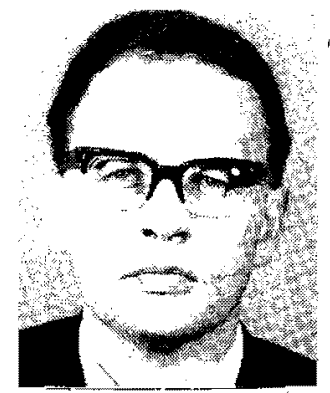

Danie F. Toerien

Utah search at the Utah Water Research Laboratory. He came to USU from the University of California at Berkeley where he was an Associate Research Engineer and Assistant Director of the Sanit ary Engineering Research Laboratory. From 1962 to 1968 he was Assistant and Associate Professor at Mississippi State University. Dr. Middlebrooks received the BCE and the MSE degrees from the University of Florida, and the Ph.D. degree from Mississippi State University. He is a registered professional engineer, and the author or co-author of some 50 publications.

Danie $F$. Toerien is currently a post doctoral scholar in the Sanitary Engineering Division, Department of Civil Engineering at the University of California, Berkeley. Before going to Berkeley he attended the University of Pretoria (South Africa) where he received both his masters and doctorate degrees in Microbiology. After employment in the South African Department of Agriculture and at the University of Pretoria, Dr. Toerien, in 1966, Joined the National Institute for Water Research of the South African Council for Scientific and Industrial Research. There he was a member of a research team investigating the biochemistry and microbiology of anaerobic digestion. At the University of California, Berkeley, he is participating in a project aimed at developing algal assays, sponsored by the Environmental Protection Agency. 


\section{TABLE OF CONTENTS}

Page

INTRODUCTION

CARBON TRANSFORMATIONS IN THE AQUATIC ENVIRONMENT

The Carbon Cycle . . . . . . . . . . . . . . . . . . . . . . 3

Synthesis of Organic Carbon Compounds . . . . . . . . . . . . . . . 3

Plant and algal photosynthesis . . . . . . . . . . . . . . 3

Bacterial photosynthesis . . . . . . . . . . . . . . . . . 3

Non-photosynthetic incorporation

of $\mathrm{CO}_{2}$. . . . . . . . . . . . . . . . . . . . 5

Degradation of Organic Matter . . . . . . . . . . . . . . 6

THE CHEMISTRY OF INORGANIC CARBON IN NATURAL

WATERS .............................9

$\mathrm{CO}_{2}-\mathrm{HCO}_{3}{ }^{-}-\mathrm{CO}=$ Equilibrium System . . . . . . . . . . . . . 9

Alkalinity and Buffering Capacity . . . . . . . . . . . . . . . . . 16

Biological Effects on $\mathrm{pH}$. . . . . . . . . . . . . . . . . . . . . 16

$\mathrm{CaCO}_{3}$ Equilibrium . . . . . . . . . . . . . . . . 19

Reaction Rates . . . . . . . . . . . . . . . . . . . 21

Chemical reaction rates .... . . . . . . . . . . . . 21

The role of the enzyme carbonic

anhydrase .................... . . 23

CARBON UTILIZATION BY ALGAE . . . . . . . . . . . . . . 25

Sources of Carbon . . . . . . . . . . . . . . . 25

Organic carbon utilization by algae . . . . . . . . . . . . . 25

Inorganic carbon utilization by algae . . . . . . . . . . . . 27

Carbon Utilization in Special Systems . . . . . . . . . . . . . 32 
Wastewater treatment systems . . . . . . . . . . . 32

Natural water bodies . . . . . . . . . . . . . . . 34

Controlled laboratory facilities . . . . . . . . . . . 34

Nutrient Utilization by Algae . . . . . . . . . . . . . . 36

Role of Carbon in Eutrophication Process . . . . . . . . . . 36

SUMMARY . . . . . . . . . . . . . . 41

REFERENCES CITED ................... . . 43 


\section{INTRODUCTION}

Natural and cultural eutrophication (enrichment with nutrients) frequently results in excessive algal growths thereby reducing the beneficial uses of surface waters (Hasler, 1947; Thomas, 1955, Edmondson et al., 1956, Oswald and Golueke, 1966, Skulberg, 1967, Mackenthun et al., 1968, Goldman and Armstrong, 1969, McGauhey et al., 1968, 1969, 1970a, 1970b). Recent reviews emphasize that the prevention of further reduction in the quality of water resources requires the implementation of effective control measures (Goldman, 1965, Stewart and Rohlich, 1967, Middlebrooks et al., 1969, Rohlich, 1969).

Effective control of cultural eutrophication must involve the manipulation of those factors which affect algal growth, i.e. light, temperature, nutrients, mixing, predation, etc. (Toerien et al., 1970). Because at the present time man can only effectively control the discharge of nutrient concentrations into aquatic systems, most past and current research on the remediation of eutrophication effects has been concerned with nutrient control. The cost of removal (or exclusion) of specific nutrients varies, so from an economic standpoint it becomes important to identify which nutrients limit algal growth for a given situation.

Algae require carbon, hydrogen, oxygen, nitrogen, phøsphorus, sulfur, magnesium, iron, potassium, various other cations, and a number of trace elements to carry out the metabolic processes necessary for growth. Only a few of these elements can be removed from water through treatment at this time. Although Goldman (1960) and Skulberg (1967) have implicated magnesium, iron and molybdenum, and other trace elements as limiting factors for algal growth in some waters, most attention has been directed towards nitrogen and phosphorus as limiting nutrients. Several reasons for this interest in nitrogen and phosphorus follow:

(1) Nitrogen and phosphorus are relatively major constituents in algae; a typical stoichiometric formula for algal biomass being $\mathrm{C}_{106} \mathrm{H}_{181} \mathrm{O}_{45} \mathrm{~N}_{16} \mathrm{P}$ (McCarty, 1970);

(2) Geochemical considerations suggest that phosphorus is probably the most frequently limiting nutrient (Hutchinson, 1957);

(3) The considerably detailed information on the behavior of nitrogen and phosphorus in nature (Hutchinson, 1957, Task Group 2610P (AWWA), 1967);

(4) The relative ease and familiarity of chemical analysis (e.g. Amer. Publ. Health Assoc., 1965) at the relatively high concentrations observed in waste waters (McGauhey, 1968): 
(5) the vast amount of research performed on the physiological and biochemical utilization of nitrogen and phosphorus (e.g. Fogg, 1959, Lewin, 1962, Kuhl, 1968);

(6) at least for phosphorus, the relative ease with which it can be removed from waste waters by chemical treatment (Wuhrmann, 1957, Rohlich, 1961).

Because phosphorus can be removed relatively easily in both economical and technical terms (e.g. Culp and Moyer, 1969) and because it has been considered to be the most probable limiting nutrient in most natural waters, proposals for constructing tertiary treatment plants for removing phosphorus from waste waters, elimination of phosphate builders in detergents, and limitations on the use of phosphorus fertilizers have all been advanced as aids in controlling eutrophication.

Recently the concept that phosphorus is the most probable limiting nutrient in natural waters has been questioned (Legge and Dingledein, 1970) and several investigators have suggested that carbon is really the most important limiting nutrient in natural waters (Lange, 1967, Kuentzel, 1969, Kerr et al., 1970, King, 1971). These considerations have now entered the realm of controversy (Kuentzel, 1969, 1970, Legge and Dingledein, 1970, Sawyer, 1970, Shapiro, 1970, Abelson, 1970, Bowen, 1970, Likens, 1971). The implication of carbon as being a major factor controlling cultural eutrophication has significant consequences. Currently removal of phosphorus from detergents has been advocated (Environmental Science and Technology, 1970, Dawson, 1970). The economic aspects of phosphorus removal and replacement with other materials for the consumer and manufacturer and the environmental effects of possible replacements (e.g. substitutes similar to the recently banned nitrito-triacetic acid (NTA)) on aquatic ecosystems have not been evaluated. Therefore, serious questioning of the role of phosphorus in the eutrophication of natural waters may be warranted. However, the possible role of other factors which can limit algal populations should be considered in light of the extensive literature which exists on the subject of algal growth.

It is the goal of this review to clarify and obtain a perspective on the role of carbon in controlling algal growth in natural waters. Information on carbon cycling and metabolism, inorganic carbon chemistry, algal utilization of carbon, and concepts of nutrient limitation will be discussed and reviewed to gain this perspective. This information will provide for a more complete understanding of the role of carbon in eutrophication. 


\title{
CARBON TRANSFORMATIONS IN THE AQUATIC ENVIRONMENT
}

\author{
The Carbon Cycle
}

To define the role of carbon in the growth of algae and hence as a factor affecting eutrophication, it is first necessary to consider the carbon cycle in aquatic environments (Figure 1). In the aquatic habitat carbon changes revolve around synthesis and degradation of organic matter, i.e. reduction of inorganic carbon into organic carbon and then oxidation of organic carbon into inorganic carbon, with a strong interdependence of these reactions upon each other. In the conversion of inorganic carbon into organic carbon the photosynthetic reactions of plants, algae and bacteria, are important, while microbial degradation of organic carbon is important in the reverse reaction.

\section{Synthesis of Organic Carbon Compounds}

Organic carbon compounds may be synthesized from $\mathrm{CO}_{2}$ in the aquatic environment through three types of reactions, (1) photosynthesis by plants and algae, (2) photosynthesis by certain bacteria, and (3) incorporation of carbon by other mechanisms.

\section{Plant and algal photosynthesis}

In its simplest form the photosynthetic reaction can be expressed as:

$$
2 \mathrm{H}_{2} \mathrm{O}+\mathrm{CO}_{2} \stackrel{\text { LIGHT }}{\longrightarrow}\left(\mathrm{CH}_{2} \mathrm{O}\right)+\mathrm{H}_{2} \mathrm{O}+\mathrm{O}_{2} \ldots . .
$$

While much is known about the intricacies of the specific biochemical reactions involved, Equation (1) only indicates the initial reactants required and the resulting products formed. The process of photosynthesis is considered to occur in two separate stages (Rabinowitch and Govindjee, 1969) designated in Figure 2. First, through the action of light (radiant energy) on the chlorophyll pigment, a high energy oxidant and a high energy reductant are formed. Then the reductant is used in the conversion of $\mathrm{CO}$ to carbohydrates (formation of potential chemical energy) while the oxidant gives rise to molecular oxygen.

\section{Bacterial photosynthesis}

In bacterial photosynthesis oxygen is not generated nor is water photometabolized, but other reduced inorganic or organic compounds are utilized 


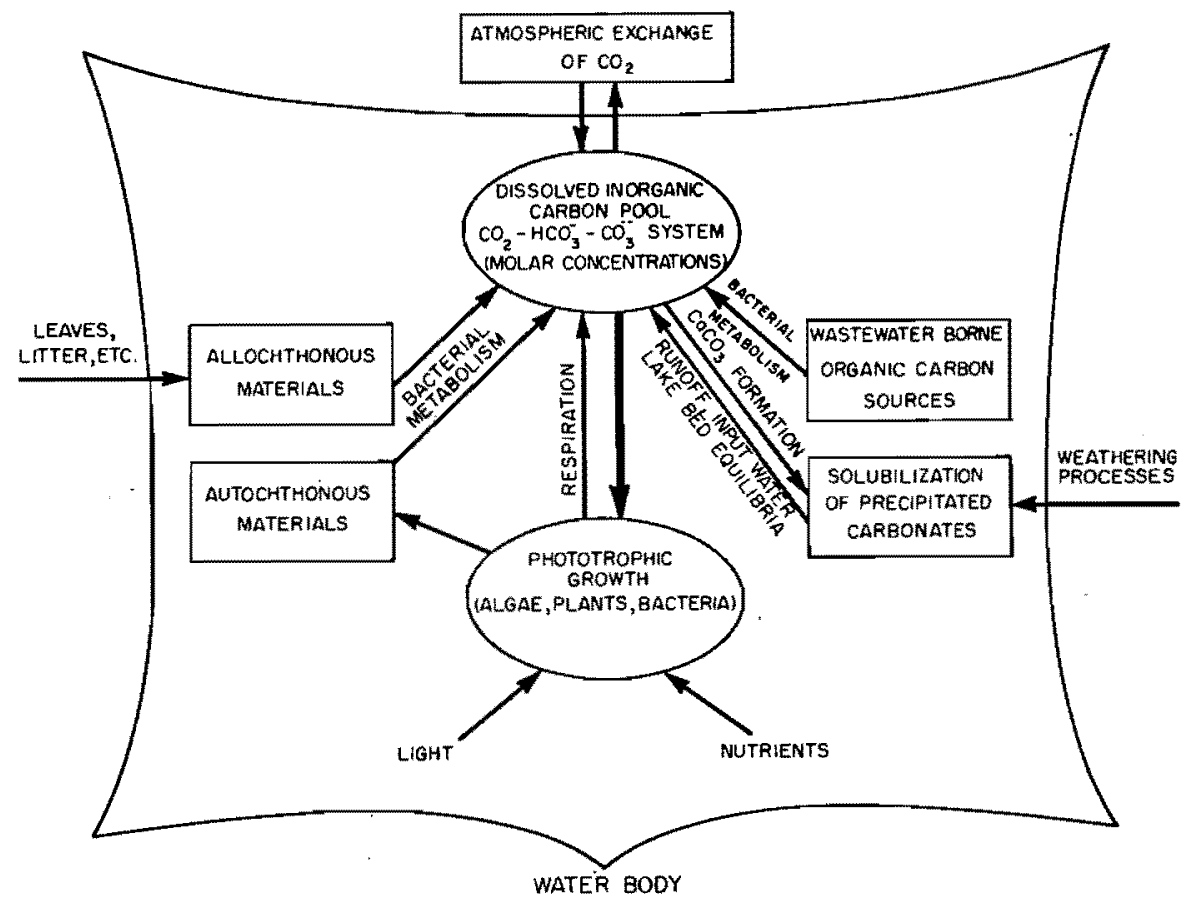

Figure 1. Carbon cycle in aquatic ecosystems.

(Pfennig, 1967). The Thiorhodaceae (purple sulfur bacteria) and the Chlorobacteriaceae (green sulfur bacteria) photometabolize reduced sulfur compounds, while the Athiorhodaceae (non-sulfur purple bacteria) photometabolize simple organic compounds (Pfennig, 1967): The simplest reaction describing bacterial photosynthesis is:

$$
\mathrm{CO}_{2}+2 \mathrm{H}_{2} \mathrm{~A} \frac{\text { BACTERIOCHLOROPHYLL }}{\text { LIGHT }}\left(\mathrm{CH}_{2} \mathrm{O}\right)+2 \mathrm{~A}+\mathrm{H}_{2} \mathrm{O} .
$$

where $\mathrm{H}_{2} \mathrm{~A}$ is either a reduced sulfur compound or a simple organic compound.

The photosynthetic bacteria occur in the anaerobic zones of all aquatic environments (Pfennig, 1967). Although always present, the non-sulfur purple bacteria are usually not visible. Purple and green sulfur bacteria are often abundant, giving rise to pink and green layers or blooms (Kaiser, 1966a, 1966b), especially below the thermocline in lakes (Bavendamm, 1924, Genovese, 1963).

Because the photosynthetic bacteria photometabolize all end products of fermentation reactions (Pfennig, 1967), they are important in the carbon cycle in aquatic habitats. In relation to the growth of green and blue-green algae and to their effect in producing unsightly masses, the photosynthetic bacteria are probably not 


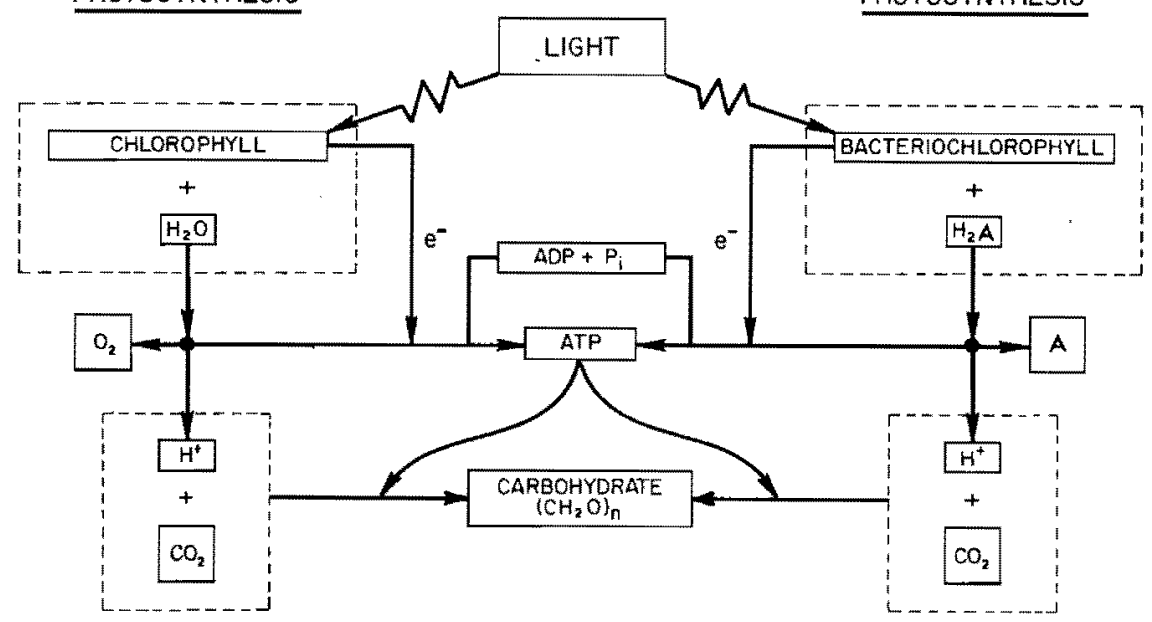

Figure 2. Mechanisms of plant and bacterial photosynthesis.

too important in natural waters. They can be the dominant biotic form in oxidation ponds which receive high organic loading and thus have a prevailing anaerobic environment (Holm and Vennes, 1970).

Non-photosynthetic incorporation of $\mathrm{CO}_{2}$

Non-photosynthetic incorporation of $\mathrm{CO}_{2}$ takes place in two broad categories, namely that by chemoautotrophic bacteria and that by heterotrophic organisms. The chemoautotrophic bacteria include a number of specialized groups which are able to use inorganic oxidizable substrates as energy sources for growth (Stanier et al., 1970). Included under the chemoautotrophic bacteria are the hydrogen bacteria, the colorless sulfur bacteria, the nitrifying bacteria, the iron bacteria, and some of the methane bacteria. Most of these bacteria are obligate autotrophs, capable of using $\mathrm{CO}_{2}$ as sole source of carbon. Because the chemoautotrophic bacteria rarely constitute a significant portion of the biomass in natural waters, incorporation of $\mathrm{CO}_{2}$ into organic material through activities of these bacteria possibly never is important in surface waters.

Some non-algal heterotrophic organisms incorporate $\mathrm{CO}_{2}$ into organic matter during their growth. For instance, the continued oxidation of acetyl coenzyme A by means of the citric acid cycle in many heterotrophs requires the simultaneous presence of oxaloacetate. If the constituents of the citric acid cycle are used in cellular synthesis, as indeed they are, a drain is put on the dicarboxylic acids in the cycle. To 
replenish this drain, anaplerotic enzymatic pathways are used (Kornberg, 1966). These anaplerotic sequences can make use of carboxylation reactions (incorporation of carbon dioxide). In such a way interconversions of pyruvate and dicarboxylic acids of the citric cycle are brought about (Mahler and Cordes, 1966). Enzymes participating in such reactions are malic enzyme (which enjoys a wide distribution in nature), pyruvate carboxylase, phosphoenolpyruvate carboxykinase, and phosphoenol pyruvic carboxylase (Mahler and Cordes, 1966). However, the incorporation of $\mathrm{CO}_{2}$ by heterotrophic organisms (other than algae) in most natural surface waters probably constitutes an insignificant portion of the total incorporation of $\mathrm{CO}_{2}$ in these waters.

\section{Degradation of Organic Matter}

Every biologically important element can be considered to pass through a continuous cycle from the non-living environment to the living environment and back to the non-living environment (Stanier et al., 1970). This cycle of matter occurs in the aquatic environment as well, giving rise to the phoenomenon termed the selfpurification of water in which moderate amounts of organic pollution are transformed into stable end products (Pelczar and Reid, 1965). These transformations are brought about by the activities of many types of microorganisms present in the aquatic habitat.

The degradation of organic matter in the aquatic habitat appears to be basically similar to that in any other habitat in which organic matter is degraded, e.g. the soil, the intestinal tracts of various animals, sewage treatment plants, etc. Under anaerobic conditions different end products are formed than under aerobic conditions, but many of these compounds formed under anaerobic conditions are further oxidized under aerobic conditions. In general, $\mathrm{CO}_{2}$ is the end product for all organic carbon compounds. For the purposes of this review a generalized scheme of organic matter degradation is presented in Table 1 . The product compounds viz. $\mathrm{CO}_{2}, \mathrm{NH}_{3}, \mathrm{NO}_{3}$, and $\mathrm{PO}_{4}$ can again be used for growth of photosynthetic organisms. 
Table 1. Generalized scheme of microbial degradation of organic waters.

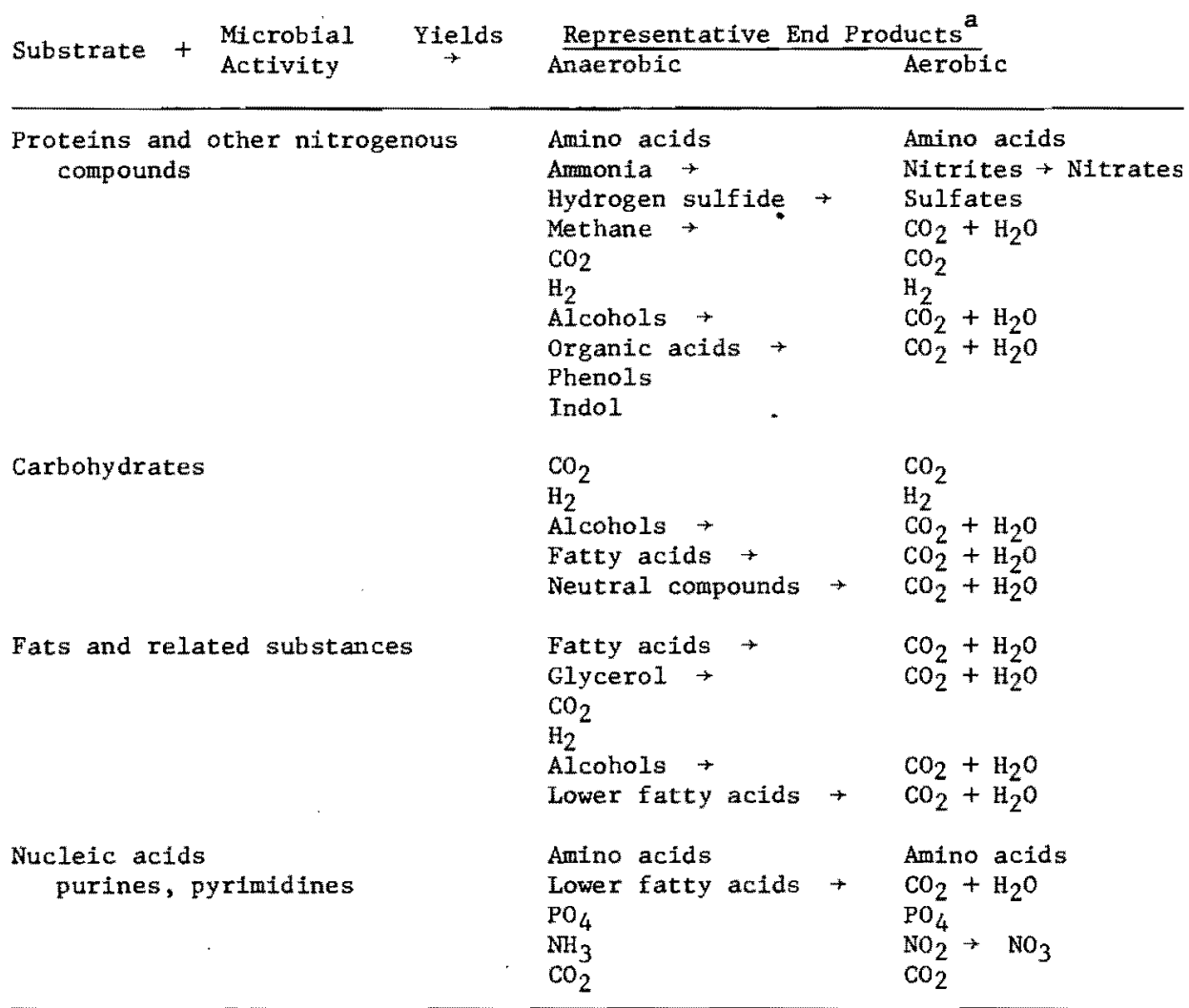

$a+$ Indicates that compound can be further oxidized under aerobic conditions by other microbes. 


\section{THE CHEMISTRY OF INORGANIC CARBON IN NATURAL WATERS}

The $\mathrm{CO}_{2}-\mathrm{HCO}_{3}{ }^{-}-\mathrm{CO}_{3}{ }^{=}$equilibrium system, a major component of the buffering system of most natural waters (Weber and Stumm, 1963a, 1963b), is affected to a large degree through changes in pH resulting from algal growth. The extraction of $\mathrm{CO}_{2}$ from an algal growth system through assimilation into algal biomass at a rate faster than it can be replaced through atmospheric $\mathrm{CO}_{2}$ diffusion, respiration, fermentation processes, and readjustment of solid carbonate equilibria leads to an increase in $\mathrm{pH}$ level. This rise in $\mathrm{pH}$ can affect algal growth in a number of ways. These include:

a. A change in the carbon species: Aqueous $\mathrm{CO}_{2}$ is reduced in concentration and the equilibrium system is shifted so that the $\mathrm{HCO}_{3}{ }^{-}$and $\mathrm{CO}_{3}{ }^{2}$ ions predominate. Research to date indicates that certain algae growing autotrophically can use only aqueous $\mathrm{CO}_{2}$ as their carbon source, while others, notably blue-green algae, dominate in higher $\mathrm{pH}$ environments and may utilize the $\mathrm{HCO}_{3}{ }^{-}$and even $\mathrm{CO}_{3}{ }^{2}$ ion directly (Jackson, 1964). A considerable controversy exists today over whether or not these ions are used directly (Holm-Hansen, 1967).

b. Solubility: The solubility of other essential nutrients, particularly phosphorus, iron and trace elements is affected. Algal growth could then become limited by one or more of these precipitated and unavailable elements.

c. Metabolic effects: Extreme $\mathrm{pH}$ values affect the metabolic mechanisms of all living organisms and algal growth rates could be altered at the higher $\mathrm{pH}$ values found in some active algal systems.

\section{$\mathrm{CO}_{2} \mathrm{HCO}_{3}-\mathrm{CO}_{3}=$ Equilibrium System}

The $\mathrm{pH}$ of the most natural waters is greatly influenced by the $\mathrm{CO}_{2} \cdot \mathrm{HCO}_{3}-$ $-\mathrm{CO}_{3}=$ equilibrium system. The system is governed by both the content of atmospheric $\mathrm{CO}_{2}$ and by the total alkalinity of the water. The entire equilibrium system can be described by the following stoichiometric equations (all constants used to describe the $\mathrm{CO}_{2}-\mathrm{HCO}_{3}{ }^{-}-\mathrm{CO}_{3}^{=}$system are from Kern (1960)):

Ionization of water

$$
\mathrm{H}_{2} \mathrm{O} \leftrightarrows \mathrm{H}^{+}+\mathrm{OH}^{-} ; \mathrm{K}=\left(\mathrm{H}^{+}\right)\left(\mathrm{OH}^{-}\right)=10^{-14} @ 25^{\circ} \mathrm{C} \ldots
$$

Solubility of $\mathrm{CO}_{2}$ in $\mathrm{H}_{2} \mathrm{O}$

$$
\mathrm{CO}_{2} \text { (gas) } \leftrightarrows \mathrm{CO}_{2}(\mathrm{aq}) ; \mathrm{CO}_{2}=\mathrm{k}_{\mathrm{CO}_{2}}{ }^{\mathrm{P}} \mathrm{CO}_{2} \ldots .
$$




$$
\begin{aligned}
& \mathrm{k}_{\mathrm{CO}_{2}}=10^{-1.5} \text { moles/atmosphere } @ 25^{\circ} \mathrm{C} \\
& \mathrm{P}_{\mathrm{CO}_{2}}=10^{-3.5} \text { for atmospheric air }
\end{aligned}
$$

Hydration of $\mathrm{CO}_{2}$

$$
\mathrm{CO}_{2}(\mathrm{aq})+\mathrm{H}_{2} \mathrm{O} \stackrel{\leftarrow}{\lessgtr} \mathrm{H}_{2} \mathrm{CO}_{3} ; \mathrm{K}_{\mathrm{q}}=\frac{\left(\mathrm{CO}_{2}\right)}{\left(\mathrm{H}_{2} \mathrm{CO}_{3}\right)} \simeq 600
$$

Since $\left(\mathrm{CO}_{2}\right)$ (aq) at equilibrium is much greater than $\left(\mathrm{H}_{2} \mathrm{CO}_{3}\right),\left(\mathrm{H}_{2} \mathrm{CO}_{3}\right) *=$ $\left(\mathrm{H}_{2} \mathrm{CO}_{3}\right)+\left(\mathrm{CO}_{2}\right)$ (aq) can be considered valid and $\left(\mathrm{H}_{2} \mathrm{CO}_{3},\right)^{*}$ will hereafter be considered to be equal to the sum of the dehydrated and hydrated forms of $\mathrm{CO}_{2}$.

First ionization of $\left(\mathrm{H}_{2} \mathrm{CO}_{3}\right)^{*}$

$$
\begin{aligned}
& \mathrm{H}_{2} \mathrm{CO}_{3}{ }^{*} \stackrel{\leftarrow}{\rightarrow} \mathrm{H}^{+}+\mathrm{HCO}_{3}{ }^{-} ; \mathrm{K}_{1}{ }^{\prime}=\frac{\left(\mathrm{H}^{+}\right)\left(\mathrm{HCO}_{3}{ }^{-}\right)}{\left(\mathrm{H}_{2} \mathrm{CO}_{3}\right)^{*}}=4.45 \times 10^{-7} \mathrm{e} 25^{\circ} \mathrm{C}(6) \\
& \left(\mathrm{K}_{1}{ }^{\prime}=\text { apparent dissociation constant }\right)
\end{aligned}
$$

Second ionization of $\left(\mathrm{H}_{2} \mathrm{CO}_{3}\right)$

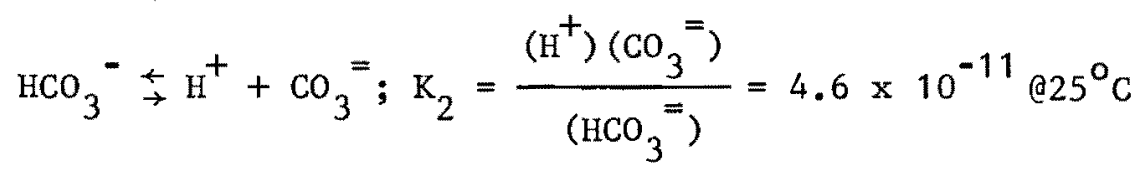

Total alkalinity of most natural waters (in equiv./liter)

$$
\begin{aligned}
& \text { Tot. Alk. }(\mathrm{ALK})=\left(\mathrm{HCO}_{3}^{-}\right)+2\left(\mathrm{CO}_{3}{ }^{-}\right)+\left(\mathrm{OH}^{-}\right)+\left(\mathrm{NH}_{3}\right) \\
& +\left(\mathrm{H}_{2} \mathrm{PO}_{4}^{-}\right)+2\left(4 \mathrm{PO}_{4}^{-}\right)+3\left(\mathrm{PO}_{4} \equiv\right)+\left(\mathrm{B}_{4}\left(\mathrm{OH}_{4}^{-}\right)-\left(\mathrm{H}^{+}\right)\right. \\
& \left(\mathrm{H}^{+}\right) \text {can be neglected for }\left(\mathrm{H}^{+}\right)<10^{-4}(\mathrm{pH}>4)
\end{aligned}
$$

Temperature and ionic strength greatly influence these equations. Morton and Lee (1968a) and Park et al. (1970) have shown the importance of considering activity rather than concentration when describing the $\mathrm{CO}_{2}-\mathrm{HCO}_{3}{ }^{-}-\mathrm{CO}_{3}{ }^{2}$ system. Morton and Lee (1968a) in their analysis of Lake Mendota in Wisconsin calculated an activity coefficient of 0.74 for the $\mathrm{CO}_{3}=$ ion, based on the water's ionic strength of 0.0045 . Similarly, Park et al. (1970) found the ionic strength of the Columbia River to be 0.0018 giving an activity coefficient for the $\mathrm{CO}_{3}{ }^{2}$ ion of 0.83 . Although most natural waters are relatively dilute solutions, these results demonstrate that activity rather than concentration must be considered in any generalized formulation of the

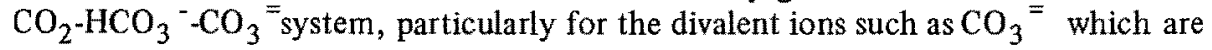


greatly influenced by ionic strength. The importance of this concept can be seen in Figure 3 where activity coefficients for the various components of the $\mathrm{CO}_{2}-\mathrm{HCO}_{3}$ $\mathrm{CO}_{3}=$ system, as a function of ionic strength, are plotted according to the data of Klotz (1964). These curves show the strong dependence of the activity of the $\mathrm{CO}_{3}$ ion on ionic strength. The mono-valent ions have less of a dependency. The need to consider activity rather than concentration in highly mineralized waters has been considered by Berner (1965), who has reviewed the role of activity coefficients in the $\mathrm{CO}_{2} \mathrm{HCO}_{3}-\mathrm{CO}_{3}{ }^{2}$ system of sea water.

Temperature as well as ionic strength greatly influences this system. Both Langelier (1946) and Dye (1952) have discussed its importance in great detail. To demonstrate this effect the thermodynamic equilibrium constants, $\mathrm{K}_{1}, \mathrm{~K}_{2}$, and $\mathrm{K}_{\mathrm{w}}$ are plotted in Figure 4 as functions of temperature according to the data of Harned and Scholes (1941), Harned and. Bonner (1945), and Harned.and Owen (1958). The constants increase with increasing temperature. Also, plotted in this figure are the solubility coefficients for $\mathrm{CO}_{2}$ in water, $\mathrm{k}_{\mathrm{CO}_{2}}$ in moles per atmosphere, as a function of temperature according to Harned and Davis (1943). In contrast to the equilibrium constants this coefficient decreases with increasing temperature.

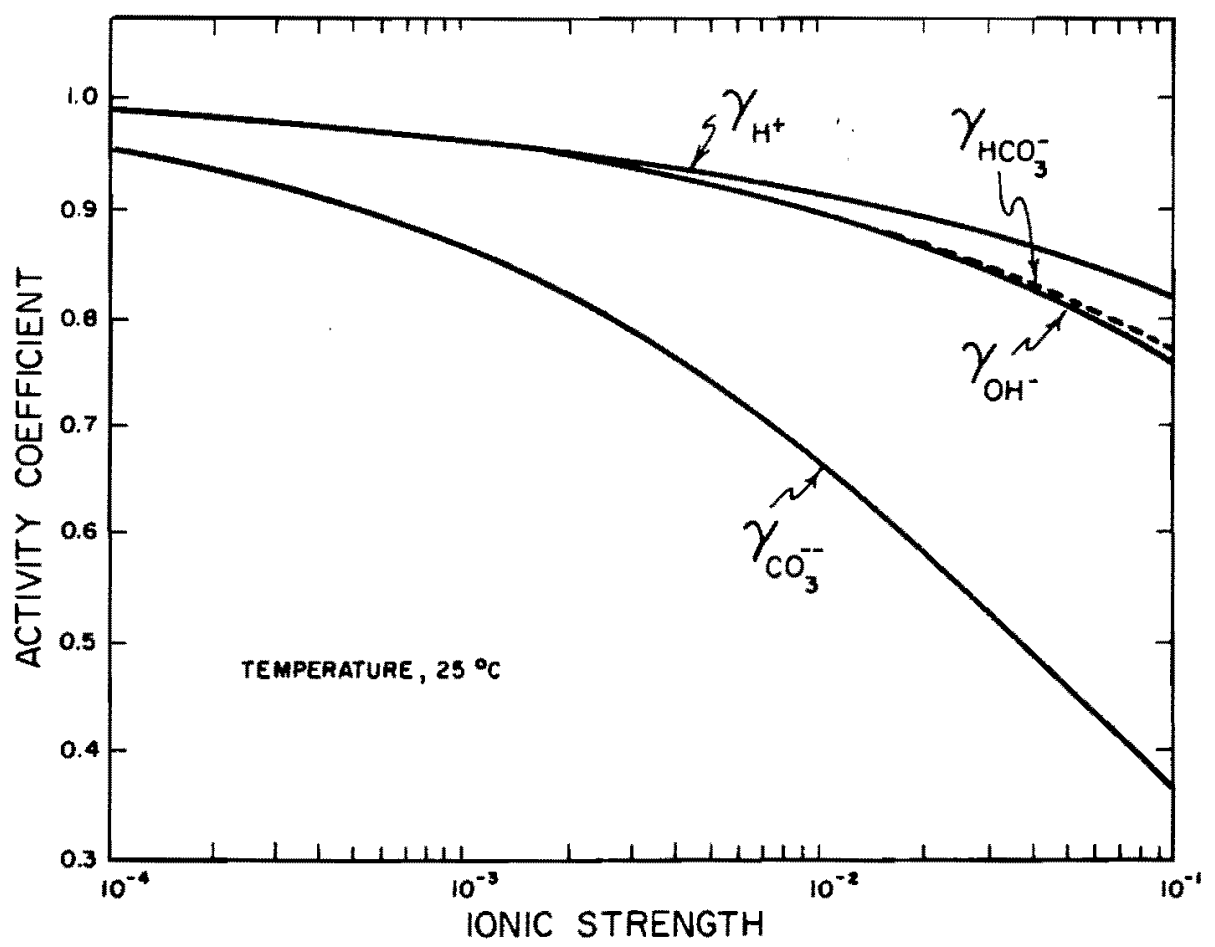

Figure 3. Effect of ionic strength on activity coefficients for components of $\mathrm{CO}_{2}$ $\mathrm{HCO}_{3}^{-}-\mathrm{CO}_{3}^{-}$system. 


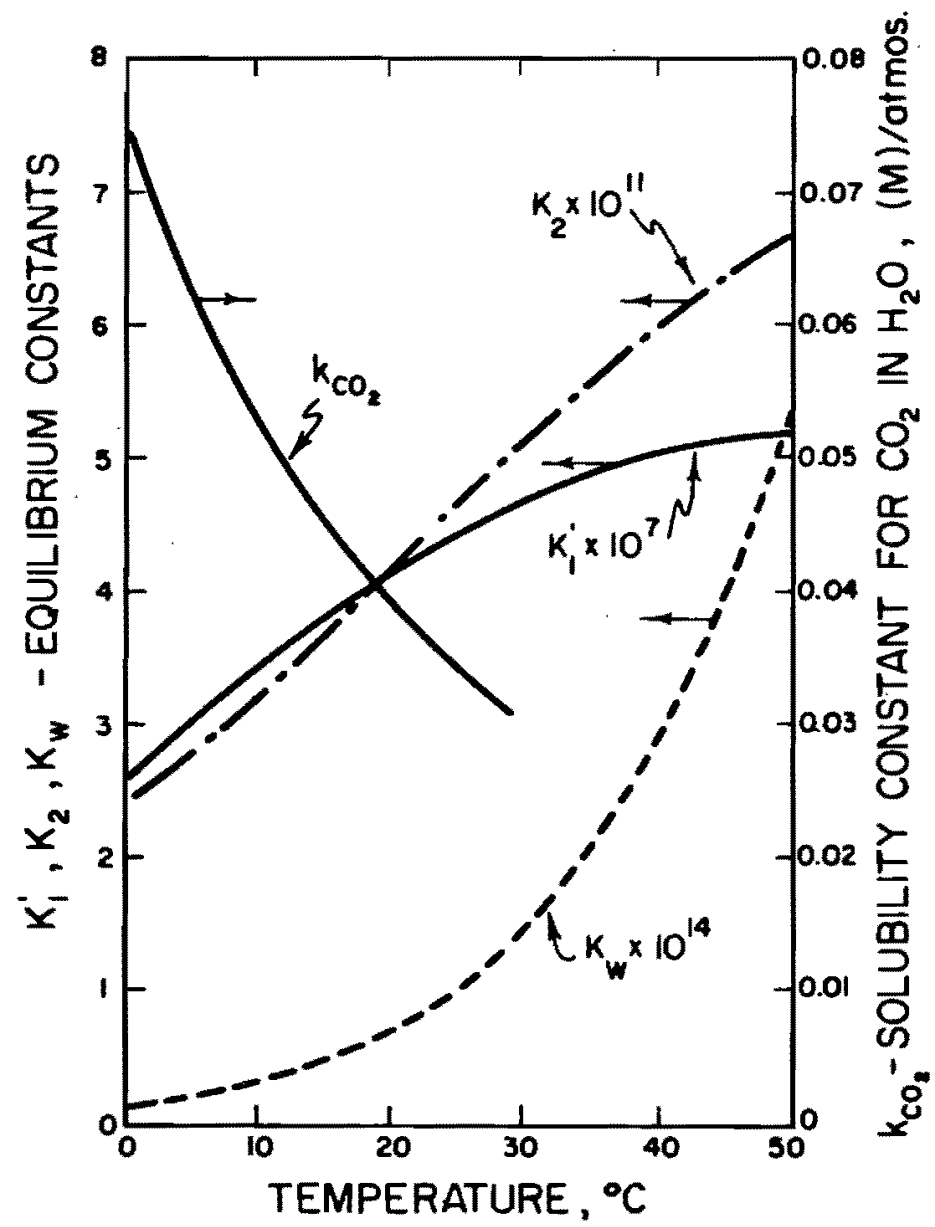

Figure 4. Effect of temperature on equilibrium constants and solubility coefficient in $\mathrm{CO}_{2} \cdot \mathrm{HCO}_{3}^{-}-\mathrm{CO}_{3}^{-}$system.

By combining and rearranging Equations (3) through (8) the equilibrium $\mathrm{pH}$ of 1 a natural water can be described. The following equations, as proposed by Weber and Stumm (1963a) and by Thomas and Trussell (1970) show this relationship:

$\left(\mathrm{H}^{+}\right)=\frac{\mathrm{K}_{\mathrm{w}}+\mathrm{K}_{1}^{\prime}\left(\mathrm{H}_{2} \mathrm{CO}_{3}\right)^{*}+}{2(\mathrm{ALK})}$

$\frac{\sqrt{\left[\mathrm{K}_{\mathrm{w}}+\mathrm{K}_{1}^{\prime}\left(\mathrm{H}_{2} \mathrm{CO}_{3}\right) *\right]^{2}+8(\mathrm{ALK}) \mathrm{K}_{1}^{\prime} \mathrm{K}_{2}\left(\mathrm{H}_{2} \mathrm{CO}_{3}\right) *}}{2(\mathrm{ALK})}$ 


$$
\mathrm{pH}=-\log _{10}\left[\frac{\mathrm{K}_{\mathrm{w}}+\mathrm{K}_{1}{ }^{\prime}\left(\mathrm{k}_{\mathrm{CO}_{2}}{ }^{\mathrm{P}} \mathrm{CO}_{2}\right)}{2(\mathrm{ALK})}+\right.
$$

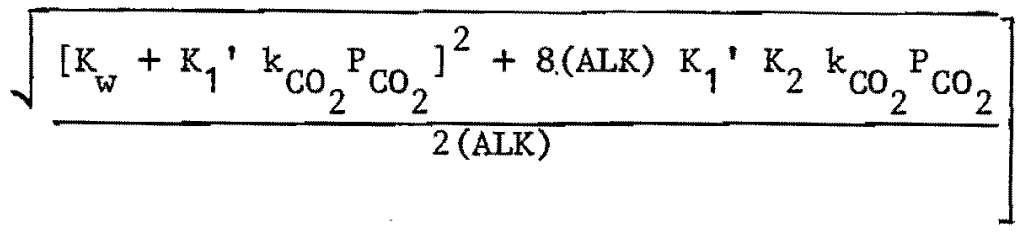

These equations hold true only for those situations where the free $\mathrm{CO}_{2}$ concentration in solution is in equilibrium with atmospheric $\mathrm{CO}_{2}$. For most natural waters this situation is rarely ever found. Stumm (1964) indicates that most natural waters are supersaturated with $\mathrm{CO}_{2}$. Morton and Lee (1968a) have made a similar claim, showing that thermal stratification plays an important role in maintaining vertical $\mathrm{CO}_{2}$ gradients in natural waters. Higher $\mathrm{CO}_{2}$ concentrations, and corresponding lower $\mathrm{pH}$ values are found nearer the bottom where bacterial activity predominates. Hutchinson (1957) in his classical work has extensively described the $\mathrm{CO}_{2} \cdot \mathrm{HCO}_{3} \cdot \mathrm{CO}_{3}=$ equilibrium system in lakes and has made a similar claim that natural water bodies are often supersaturated with $\mathrm{CO}_{2}$. He has greatly stressed the point that continually occurring complex interactions such as biological activity and heterogeneous chemical reactions, greatly affect the $\mathrm{CO}_{2}$ concentration present in a water body,

Horne (1969) has reviewed the latest work on $\mathrm{CO}_{2}$ equilibrium in the oceans and reports that while the Pacific Ocean is undersaturated to a large degree, the Indian Ocean and the South Atlantic near the equator are supersaturated. Keeling (1968) has developed a map showing the distribution of $\mathrm{CO}_{2}$ in the oceans at the surface. His conclusions are that while supersaturation occurs at the equator, undersaturation occurs toward the poles. Also, Kelley and Hood (1969) have reported that $\mathrm{CO}_{2}$ concentrations in the North Pacific Ocean and the Bering Sea are greatly affected by the currents and the river discharges. The supersaturation with dissolved $\mathrm{CO}_{2}$ at the entrance to Puget Sound in Washington was equivalent to an atmospheric $\mathrm{CO}_{2}$ concentration of 0.09 percent. Park et al. (1969) also showed that the dissolved $\mathrm{CO}_{2}$ concentration of the Columbia River was greatly in excess of equilibrium values. Other rivers in the region displayed a similar characteristic (Park et al., 1970).

Referring back to Equation (10), the equilibrium $\mathrm{pH}$ of a natural water increases with an increase in total alkalinity. This relationship is shown in Figure 5 in which curves are plotted for varying temperatures (Thomas and Trussell, 1970).

The molar concentration of all three carbon species making up the equilibrium system can be described in terms of the $\mathrm{pH}$ and alkalinity of a given system by the following equations: 
$\mathrm{C}_{\mathrm{T}}=\left(\mathrm{H}_{2} \mathrm{CO}_{3}\right)^{*}+\left(\mathrm{HCO}_{3}^{-}\right)+\left(\mathrm{CO}_{3}{ }^{-}\right) \ldots \ldots \ldots \ldots(11)$ in which $\mathrm{C}_{\mathrm{T}}$ equals the total molar concentration of carbon

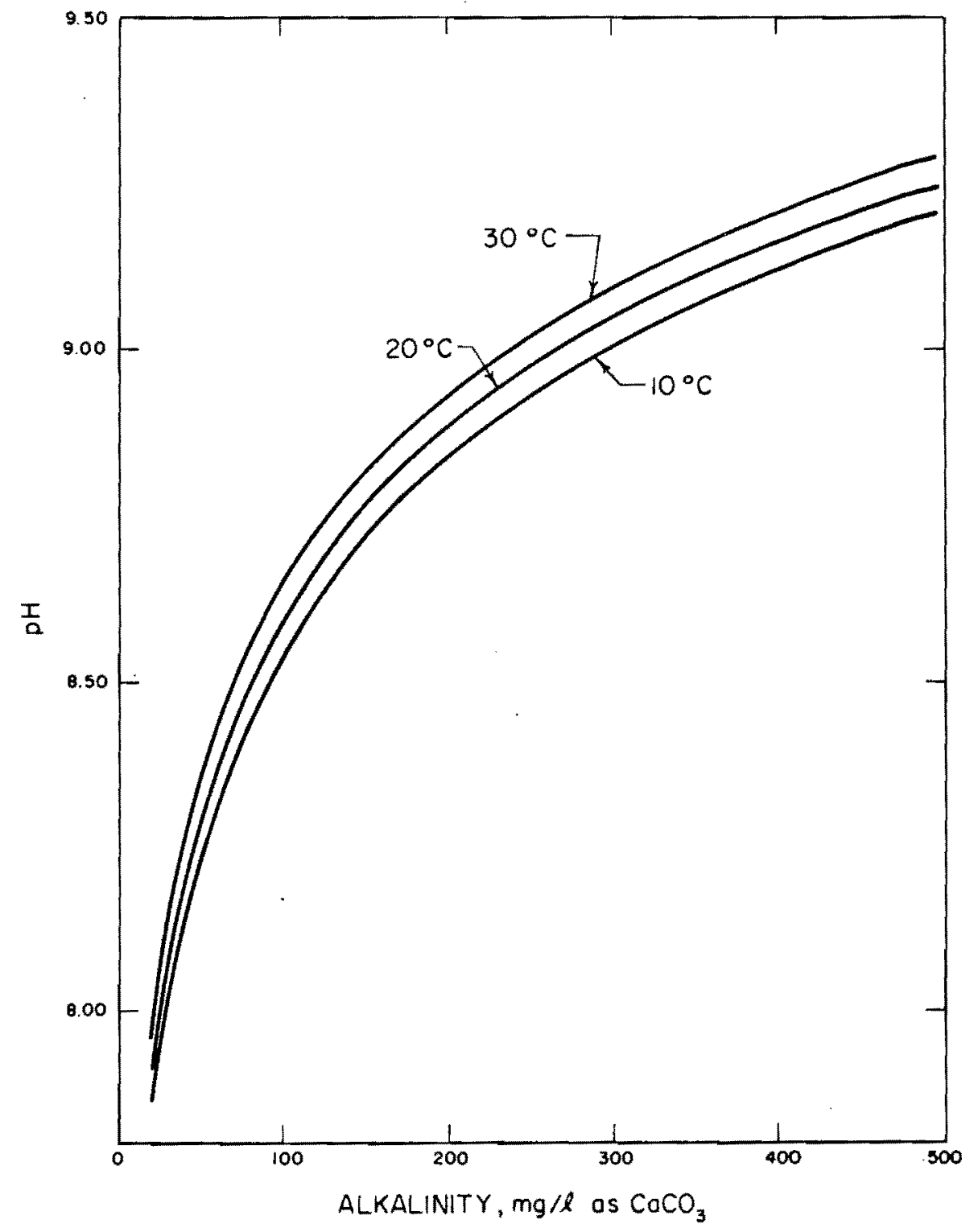

igure 5. Effect of alkalinity on equilibrium $\mathrm{pH}$ for aquatic system exposed to at mosphere $\left(\mathrm{CO}_{2}=0.03\right.$ percent). From Thomas and Trussel (1970). 


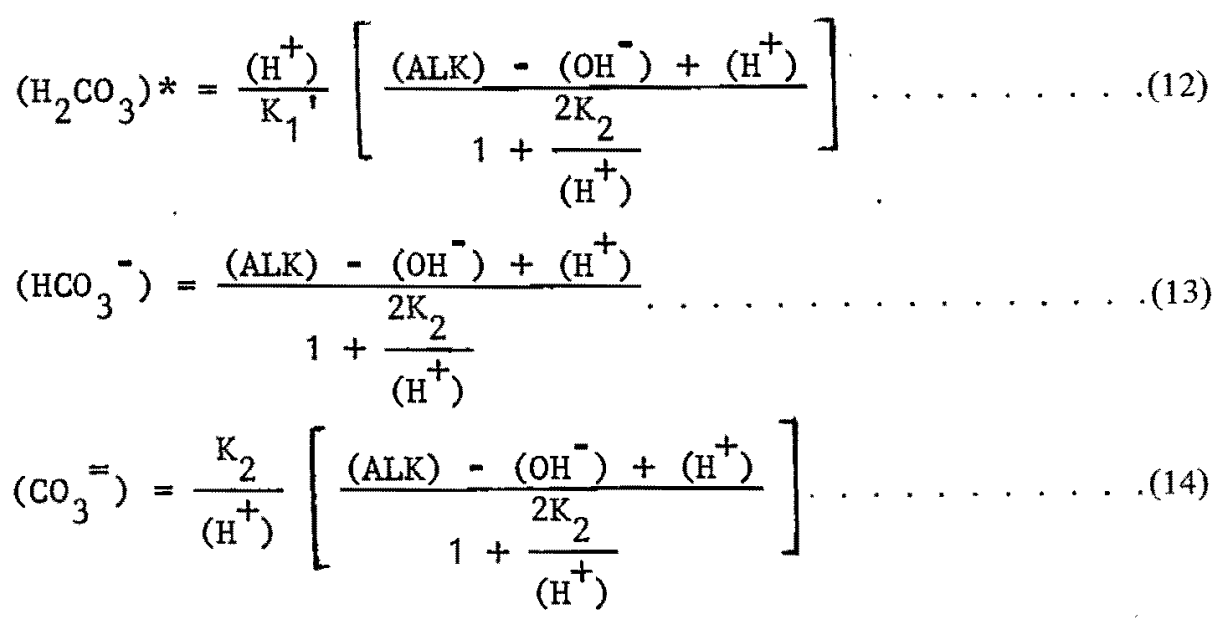

A distribution diagram based upon Equations (11) through (14) showing the relative proportions of all three species as a function of $\mathrm{pH}$ (independent of alkalinity concentration) is presented in Figure 6 in which the relative proportions of the three carbon species change as a function of $\mathrm{pH}$. However, when the system is in equilibrium with atmospheric $\mathrm{CO}_{2}$ the concentration of free $\mathrm{CO}_{2}$ in solution remains constant for all $\mathrm{pH}$ values while the concentration of the bicarbonate and carbonate species changes as a function of the total carbon alkalinity.

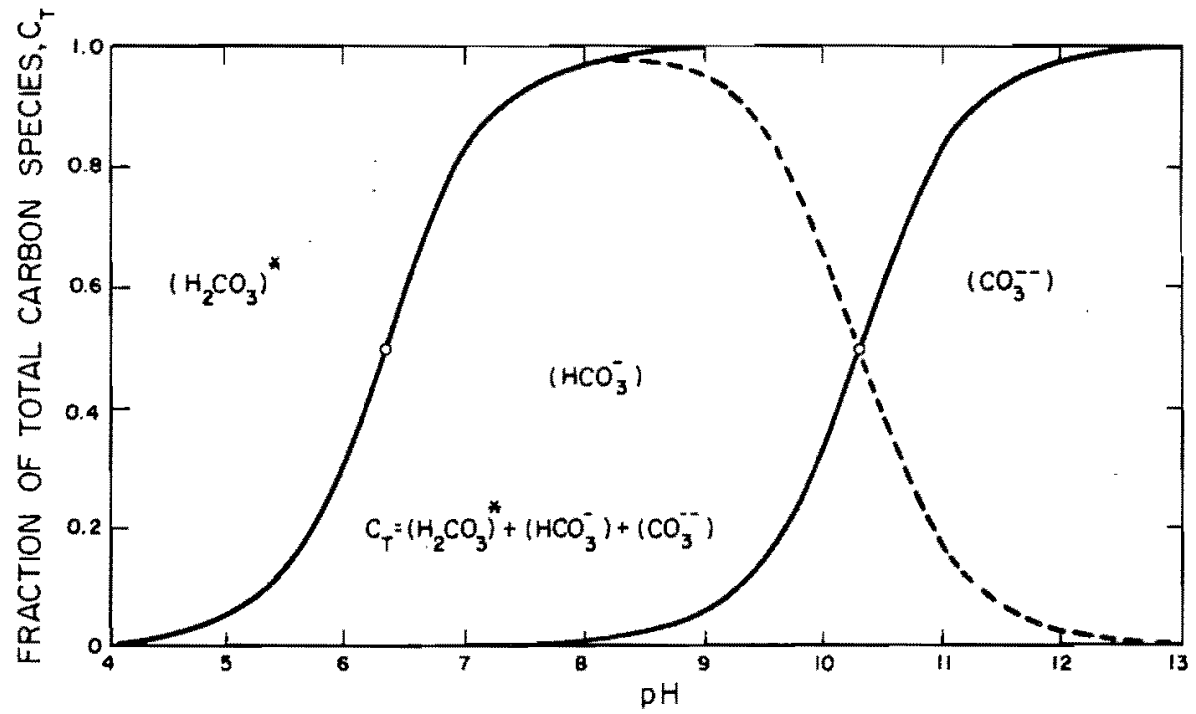

Figure 6. Effect of $\mathrm{pH}$ on distribution of inorganic carbon species in $\mathrm{CO}_{2}-\mathrm{HCO}_{3}$ $-\mathrm{CO}_{3} \bar{s}$ system. 


\section{Alkalinity and Buffering Capacity}

The operational definition of alkalinity for most natural waters, as defined by Equation (8), implies that the $\mathrm{CO}_{2}-\mathrm{HCO}_{3}^{-}-\mathrm{CO}_{3}=$ equilibrium system is the major buffering system of fresh waters. As contrasted to sea water, where the silicate and borate concentrations are high and are major contributors to the alkalinity and buffering capacity, particularly the silicates (Sillen, 1961; Garrels, 1965), fresh waters are normally quite low in these constituents. Also, phosphates and ammonia (at high $\mathrm{pH}$ ), which can also contribute to a water's total alkalinity, are found only in relatively minute concentrations in fresh waters. They usually make up such a minor component of the total alkalinity that they are neglected in making such a determination.

Thus, the apparent major buffering system of a fresh water is composed of the $\mathrm{CO}_{2} \cdot \mathrm{HCO}_{3}-\mathrm{CO}_{3}=$ system. However, as pointed out by Weber and Stumm (1963a), the homogeneous $\mathrm{CO}_{2}-\mathrm{HCO}_{3}{ }^{-}-\mathrm{CO}_{3}{ }^{2}$ buffering system, although an important component of the overall buffering capacity of a natural water, is itself greatly affected by the complicated network of heterogeneous and biological reactions continually occurring in the aquatic environment as the whole system strives toward, but seldom reaches, equilibrium. Stumm (1964, 1967), Bricker and Garrels (1967), and Bostrom (1967) have suggested that heterogeneous reactions involving solid phases, such as clays and other minerals, may be the principal buffering agents in fresh waters. They point out that there is a dearth of information in this area and stress the need for further research.

\section{Biological Effects on pH}

Biological activity can alter the $\mathrm{pH}$ of a natural water in many ways. Table 2 , taken from Weber and Stumm (1963a), has depicted the various biological reactions that may alter $\mathrm{pH}$. As an example, Berner et al. (1970), has recently demonstrated the effect of sulfate reduction in marine sediments on increasing alkalinity and hence buffering capacity. Since many of these reactions are localized in the sense that they occur only in certain portions of an aquatic ecosystem (i.e. photosynthesis in the photic zone, reduction processes in anaerobic portions of the bottom sediments), vertical gradients of decreasing $\mathrm{pH}$ with increasing depth are very often found in natural waters. These gradients are maintained through thermal stratification. With the onset of spring and fall overturn, relatively equal $\mathrm{pH}$ levels are produced for short times throughout the volume of the water body. The formation of new thermal gradients together with the continuous biological activity once more causes gradients, to form. (See review by Lee and Hoadley, 1967.)

The effect of actively growing algae on the $\mathrm{pH}$ of surface waters can be better understood by an analysis of the complete photosynthetic reaction. This reaction should show the assimilation of all nutrients and the formation of complete products. Equation (1) should thus be expanded from its simplified form.

As an example, the assimilation of nitrogen affects the $\mathrm{pH}$ of a water in either direction depending on the form of nitrogen being assimilated. If $\mathrm{NH}_{4}{ }^{+}-\mathrm{N}$ is used the $\mathrm{pH}$ will decrease, while the utilization of $\mathrm{NO}_{3}^{-}-\mathrm{N}$ will cause a rise in $\mathrm{pH}$. This phenomenon has been observed by a number of researchers (Trelease and Trelease, 
Table 2. Biologically mediated reactions affecting pH in natural water systems.*

\begin{tabular}{llc}
\hline \hline \multicolumn{1}{c}{ Process } & \multicolumn{1}{c}{ Reaction } & Effect on $\mathrm{pH}$ \\
\hline Photosynthesis & $6\left(\mathrm{CO}_{2}\right)+6\left(\mathrm{H}_{2} \mathrm{O}\right)+\left(\mathrm{C}_{6} \mathrm{H}_{12} \mathrm{O}_{6}+6 \mathrm{O}_{2}\right)$ & Increase \\
Respiration & $\left(\mathrm{C}_{6} \mathrm{H}_{12} \mathrm{O}_{6}+6 \mathrm{O}_{2}\right)+6\left(\mathrm{CO}_{2}\right)+6\left(\mathrm{H}_{2} \mathrm{O}\right)$ & Decrease \\
Methane Fermentation & $\left(\mathrm{C}_{6} \mathrm{H}_{12} \mathrm{O}_{6}\right)+3\left(\mathrm{CO}_{2}\right)+3\left(\mathrm{CH}_{4}\right)+6\left(\mathrm{CO}_{2}\right)$ & Decrease \\
Nitrification & $\left.\left(\mathrm{NH}_{4}{ }^{+}\right)+2\left(\mathrm{O}_{2}\right)+\left(\mathrm{NO}_{3}\right)+\mathrm{H}_{2} \mathrm{O}\right)+2\left(\mathrm{H}^{+}\right)$ & Decrease \\
Denitrification & $5\left(\mathrm{C}_{6} \mathrm{H}_{12} \mathrm{O}_{6}\right)+24\left(\mathrm{NO}_{3}\right)+24\left(\mathrm{H}^{+}\right) \rightarrow 30\left(\mathrm{CO}_{2}\right)+12\left(\mathrm{~N}_{2}\right)+42\left(\mathrm{H}_{2} \mathrm{O}\right)$ & Increase \\
Sulfide Oxidation & $\left(\mathrm{HS}^{-}\right)+2\left(\mathrm{O}_{2}\right) \rightarrow\left(\mathrm{SO}_{4}\right)+\left(\mathrm{H}^{+}\right)$ & Decrease \\
Sulfate Reduction & $\left(\mathrm{C}_{6} \mathrm{H}_{12} \mathrm{O}_{6}\right)+3\left(\mathrm{SO}_{4}={ }^{-}\right)+3\left(\mathrm{H}^{+}\right) \rightarrow 6\left(\mathrm{CO}_{2}\right)+3\left(\mathrm{HS}^{-}\right)+6\left(\mathrm{H}_{2} \mathrm{O}\right)$ & Increase \\
\hline
\end{tabular}

* From Weber and Stumm (1963a) 
1935. Cramer and Myers. 1948. Davis et al. 1953). Cramer and Myers (1948), working with Chlorella. proposed the following stoichiometric equations to describe this occurrence:

Nitrate Assimilation

$$
\begin{aligned}
1.0\left(\mathrm{NO}_{3}{ }^{\prime}\right) & +5.7\left(\mathrm{CO}_{2}\right)+5.4\left(\mathrm{H}_{2} \mathrm{O}^{2} \stackrel{\text { LIGHT }}{\longrightarrow}\left(\mathrm{C}_{5.7} \mathrm{H}_{9.8} \mathrm{O}_{2.3^{\mathrm{N}}} \stackrel{\text {. }}{ }\right)\right. \\
& +8.25\left(\mathrm{O}_{2}\right)+1.0\left(\mathrm{OH}^{-}\right) \ldots \ldots . . . \ldots(15)
\end{aligned}
$$

Ammonia Assimilation

$$
\begin{aligned}
1.0\left(\mathrm{NH}_{4}^{+}\right) & +7.6\left(\mathrm{O}_{2}\right)+17.7\left(\mathrm{H}_{2} \mathrm{O}\right) \stackrel{\text { LIGHT }}{\longrightarrow}\left(\mathrm{C}_{7.6} \mathrm{H}_{8.1^{0}} \stackrel{\mathrm{L}^{\mathrm{N}} 1.0^{\mathrm{N}}}{ }\right) \\
& +7.6\left(\mathrm{O}_{2}\right)+15.2\left(\mathrm{H}_{2} \mathrm{O}\right)+1.0\left(\mathrm{H}^{+}\right) \ldots . . . .(16)
\end{aligned}
$$

These equations explain the opposite effects on $\mathrm{pH}$ caused by either $\mathrm{NO}_{3}{ }^{-}$or $\mathrm{NH}_{4}{ }^{+}$assimilation. Every mole of $\mathrm{NO}_{3}{ }^{-}$assimilated results in the formation of one mole of $\mathrm{OH}^{-}$, thus raising the $\mathrm{pH}$. $\mathrm{NH}_{4}{ }^{+}$assimilation, on the other hand, leads to the production of one mole of $\mathrm{H}^{+}$for every mole of $\mathrm{NH}_{4}{ }^{+}$assimilated, with a resulting decrease in $\mathrm{pH}$.

As previously stated, algae can utilize $\mathrm{CO}_{2}$ from four major sources in a natural water: (1) From $\mathrm{CO}_{2}$ diffused from the atmosphere; (2) from the respiration of heterotrophic forms; (3) from anaerobic fermentation; and (4) from bicarbonate alkalinity. The first three sources provide a direct supply of $\mathrm{CO}_{2}$. The alkalinity, on the other hand, provides $\mathrm{CO}_{2}$ by a continual readjustment of the concentrations of the various carbon sources making up the $\mathrm{CO}_{2}-\mathrm{HCO}_{3}{ }^{-} \mathrm{CO}_{3}{ }^{2}$ system as shown by the following equations:

$$
\begin{aligned}
& 2\left(\mathrm{HCO}_{3}^{-}\right) \div\left(\mathrm{CO}_{3}^{-}\right)+\left(\mathrm{H}_{2} \mathrm{O}\right)+\left(\mathrm{CO}_{2}\right) \ldots . . . . .(17) \\
& \left(\mathrm{HCO}_{3}{ }^{-}\right)+\left(\mathrm{H}_{2} \mathrm{O}\right) \stackrel{\leftarrow}{\lessgtr}\left(\mathrm{H}_{2} \mathrm{O}\right)+\left(\mathrm{CO}_{2}\right)+\left(\mathrm{OH}^{-}\right) \\
& \left(\mathrm{CO}_{3}{ }^{=}\right)+\left(\mathrm{H}_{2} \mathrm{O}\right) \stackrel{\leftarrow}{\rightarrow}\left(\mathrm{CO}_{2}\right)+2\left(\mathrm{OH}^{-}\right) \text {. }
\end{aligned}
$$

Typically, the $\mathrm{pH}$ of natural waters is about 8.3 where $\mathrm{HCO}_{3}{ }^{-}$is the major ion (see Figure 6). Thus, as $\mathrm{CO}_{2}$ is extracted from solution by growing algae at a $\mathrm{pH}$ around 8.3, additional carbon dioxide is provided through these reactions. Both Equations (17) and (18) describe the principal reactions, with the reaction in Equation (17) being the dominant of the two. As the $\mathrm{pH}$ rises the $\mathrm{CO}_{3}{ }^{=}$form becomes the major carbon species and it, too, can be converted directly to $\mathrm{CO}_{2}$ by a hydration process as shown in Equation (19). This reaction similarly results in a $\mathrm{pH}$ rise. It is not uncommon to have $\mathrm{pH}$ values as high as 10 to 11 in active algal systems such as waste stabilization ponds. This phenomenon has been observed by a number of researchers (Golueke et al., 1962, Pipes, 1962b, Beck et al., 1969). This rise in pH 
gives evidence that the $\mathrm{CO}_{2}$ supplied from the first three sources mentioned is either unavailable (i.e. diffusion gradients) or insufficient to meet the demands of the growing algae and that a further demand is placed on the bicarbonate alkalinity through a readjustment of the $\mathrm{CO}_{2}-\mathrm{HCO}_{3}{ }^{-}-\mathrm{CO}_{3}=$ system. It is obvious then that even when the free $\mathrm{CO}_{2}$ content of a water is insufficient to meet the demand of the algae, the $\mathrm{HCO}_{3}{ }^{-}$and $\mathrm{CO}_{3}{ }^{2}$ forms can continually supply free $\mathrm{CO}_{2}$ for algal utilization. Deuser (1970) showed that the carbon utilized by the diatom Chaetoceros curvisetum during a heavy bloom condition in the Black Sea was derived from inorganic carbon species other than free $\mathrm{CO}_{2}$ after the initial free $\mathrm{CO}_{2}$ was depleted.

Sawyer and McCarty (1967) point out that no changes in the total alkalinity of the system occur when free $\mathrm{CO}_{2}$ is utilized by algae since there is no change from electrical neutrality. However, when and if the $\mathrm{HCO}_{3}{ }^{\circ}$ ion is used directly there would be a decrease in alkalinity proportional to its uptake. Similarly, as the $\mathrm{pH}$ rises due to algal growth $\mathrm{CO}_{3}{ }{ }^{2}$ and eventually $\mathrm{OH}^{-}$will begin to precipitate out of solution with a corresponding reduction in alkalinity. Also the concentration of other alkalinity components such as phosphates could be affected by algal growth and significant effects on the total alkalinity could occur depending on the relative concentrations of all the alkalinity components of the system.

\section{$\mathrm{CaCO}_{3}$ Equilibrium}

While the literature dealing with the purely chemical aspects of $\mathrm{CaCO}_{3}$ equilibrium in natural waters is extensive, surprisingly little attention has been given to the role of $\mathrm{CaCO}_{3}$ and phytoplankton activity. The chemistry of $\mathrm{CaCO}_{3}$ formation is extremely complex. As pointed out by Bricker and Garrels (1967), $\mathrm{CaCO}_{3}$ exists in a number of polymorphic and hydrated forms, although the two principal forms found in the sediments of natural waters appear to be calcite and aragonite. Many natural waters are supersaturated with $\mathrm{CaCO}_{3}$, both in the calcite and aragonite forms (Bricker and Garrels, 1967) and many areas of the oceans are saturated with calcite (Weyl, 1961, Schmalz and Chave, 1963, Dietrich, 1963, Siever et al., 1965). Peterson (1966) has shown that waters in the Pacific are unsaturated with respect to calcite except at the surface. Morton and Lee (1968b) have demonstrated the importance of ion pair formation, particularly with magnesium, on $\mathrm{CaCO}_{3}$ formation in ocean waters.

In natural fresh waters, $\mathrm{CaCO}_{3}$ saturation is not as common as it is in ocean waters. Kramer (1967) has studied $\mathrm{CaCO}_{3}$ formation in the Great Lakes and indicates that saturation is very temperature dependent, and for the observed temperatures Lake Erie and Lake Ontario are mostly unsaturated. Morton and Lee (1968a) have found Lake Mendota in Wisconsin to be unsaturated with respect to $\mathrm{CaCO}_{3}$ in the bottom layers while supersaturated in the surface waters.

Weber and Stumm (1963a, 1963b) and Kleijn (1965) have shown the effect of $\mathrm{CaCO}_{3}$ saturation on the buffering capacity of a natural water. A water saturated with $\mathrm{CaCO}_{3}$ is considerably more buffered than the same water which is unsaturated. It follows that the water in its heterogeneous natural environment is more strongly buffered than the same water studied in the laboratory. Thus, factors other than the homogeneous $\mathrm{CO}_{2}-\mathrm{HCO}_{3}{ }^{-}-\mathrm{CO}_{3}=$ equilibrium system help control the buffering 
capacity of these waters. The role of this phenomenon in supplying or denying carbon for the growth of algae is still unclear. For example, the observation that Charophytes become incrusted with $\mathrm{CaCO}_{3}$ during growth and yet are dominant in waters saturated with $\mathrm{CaCO}_{3}$ seems to indicate that at least some plants are able to extract sufficient $\mathrm{CO}_{2}$ from $\mathrm{CaCO}_{3}$ saturated waters (Forsberg, 1965). Thermodynamically, it would take considerable energy to cause the $\mathrm{CO}_{2}$ to become available from solid phase $\mathrm{CaCO}_{3}$ for algal growth without the addition of $\mathrm{H}^{+}$. Therefore the utilization of $\mathrm{CO}_{2}$ would lead to a rise in $\mathrm{pH}$ and actually lead to a decrease in available inorganic carbon for growth as in the following reaction which would predominate at a $\mathrm{pH}$ greater than 6.5 :

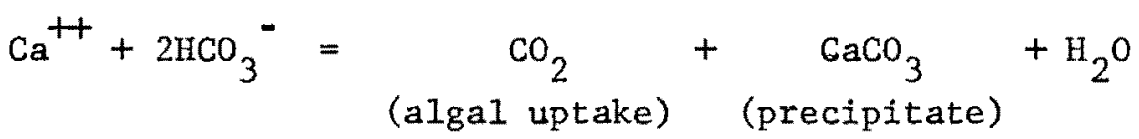

Hutchinson (1957) applying the fact that the carbonate in natural limestone contains no ${ }^{14} \mathrm{C}$ has observed. that only a relatively few hard water lakes have lower ${ }^{14} \mathrm{C}$ content than the atmosphere. This indicates that most of the carbon in lake systems is of modern origin and thus enters the aquatic system as allochthonous material or directly from the air. This further suggests that little $\mathrm{CO}_{2}$ would be available from $\mathrm{CaCO}_{3}$.

In the time span of a transient algal bloom the solid phase $\mathrm{CaCO}_{3}$ system may not have any effect on the availability of carbon since the rate at which $\mathrm{CaCO}_{3}$ goes into and out of solution is slow. Thus, the maintenance of the equilibrium system may not keep pace with the changes in the $\mathrm{CO}_{2} \cdot \mathrm{HCO}_{3}^{-}-\mathrm{CO}_{3}{ }^{2}$ system due to photosynthetic activity. Also, other factors present in a natural water may accelerate or hinder $\mathrm{CaCO}_{3}$ precipitation. Chave (1965) and Chave and Suess $(1967,1970)$ have shown that organic compounds coat $\mathrm{CaCO}_{3}$ precipitates, thus preventing their return to solution under otherwise favorable conditions. Others (Oppenheimer, 1961, Greenfeld, 1963) have shown accelerated $\mathrm{CaCO}_{3}$ precipitation in the presence of bacteria. Simkiss (1964) has shown the inhibitory effect of certain organophosphates on the precipitation of $\mathrm{CaCO}_{3}$ in sea water. Eyster (1958) has shown a similar affect on $\mathrm{CaCO}_{3}$ precipitation by inorganic phosphates. He suggests that the formation of marl deposits is associated with phosphate deficiencies. Stumm and Leckie (1970) have demonstrated the buildup of hydroxyapatite on solid $\mathrm{CaCO}_{3}$ surfaces, stressing the point that this phenomenon is a major factor controlling the resolubilization of phosphates in natural waters. Paasche $(1963,1964)$ and Steemann Nielsen (1966) have demonstrated in detail the mechanisms governing $\mathrm{CaCO}_{3}$ precipitation due to the growth of the marine coccolithophorid, Coccolithus huxleyi.

Because of the great complexity involved in $\mathrm{CaCO}_{3}$ chemistry, it is difficult to ascertain its role in the total $\mathrm{CO}_{2} \cdot \mathrm{HCO}_{3}{ }^{-}-\mathrm{CO}_{3}{ }^{2}$ system with respect to the availability of inorganic carbon for algal growth. One would surmise that $\mathrm{CaCO}_{3}$ would have minimal effect, but further research is required before $\mathrm{CaCO}_{3}$ chemistry can be related to the problems of eutrophication. 


\section{Reaction Rates}

If carbon were limiting in an algal bloom, the slowest reaction involved in the chemical transformation of the ionic forms of inorganic carbon to free $\mathrm{CO}_{2}$ could be rate limiting and could be the controlling factor governing the utilization of inorganic carbon in photosynthesis. This concept is a key point in any discussion of carbon limitations in natural waters; yet there is almost a complete absence of information on this subject in the literature.

\section{Chemical reaction rates}

Kern (1960) has reviewed the research on $\mathrm{CO}_{2}$ hydration and dehydration and points out that while the reactions described in Equations (6) and (7) are instantaneous, the hydration and dehydration of $\mathrm{CO}_{2}$ as described in Equation (5) is a relatively slow step. The slowness of the dehydration step was claimed by Hood and Park (1962) to be the factor favoring direct bicarbonate utilization by certain marine phytoplankton. Watt and Paasche (1963) and Steemann Nielsen (1963) have effectively disputed this claim.

Dehydration of carbon dioxide can occur in one of two ways, depending on the $\mathrm{pH}$. For $\mathrm{pH}$ values below 8 the reaction described in Equation (5) occurs. At $\mathrm{pH}$ values greater than 10 , dehydration can occur via the following reaction (Kern, 1960):

$$
\mathrm{HCO}_{3} \stackrel{-}{\leftarrow} \mathrm{CO}_{2}+\mathrm{OH}^{-}
$$

Between $\mathrm{pH}$ values of 8 and 10 both methods of dehydration are significant. Also in this $\mathrm{pH}$ range the normal dehydration of $\mathrm{H}_{2} \mathrm{CO}_{3}$ to $\mathrm{CO}_{2}$ and $\mathrm{H}_{2} \mathrm{O}$ is catalyzed by the presence of $\mathrm{OH}^{*}$ ions (Kiese and Hastings, 1940).

Considerable research has been performed on determining the rate constants for the dehydration reaction in Equation (5) (Faurholt, 1925, Brinkman et al., 1933, Roughton, 1941, Scheurer et al., 1958, Sirs, 1958). Roughton (1941), using a thermometric method, determined the rate constant for the dehydration process according to Equation (5) for various temperatures. These results are plotted in Figure 7 and show a strong temperature dependency of the rate constant. At a temperature of $25^{\circ} \mathrm{C}$ the rate constant is $26.6 \mathrm{sec}^{-1}$. Rabinowitch (1951) has reported the rate constant at $25^{\circ} \mathrm{C}$ for the dehydration reaction in Equation (20) to be $0.47 \times 10^{-4} \mathrm{sec}^{-1}$, considerably slower than in Equation (5), while Kern (1960) reviewed the literature and found it to be $2 \times 10^{-4} \mathrm{sec}^{-1}$. Thus, can a situation occur where the rate of $\mathrm{CO}_{2}$ assimilation by photosynthesizing algae during a bloom condition be so rapid that the rate of dehydration of $\mathrm{H}_{2} \mathrm{CO}_{3}$ becomes a rate-limiting step? Rabinowitch (1951) has attempted to answer this question by developing a hypothetical situation where the following conditions prevailed: 1) A pH of over 10; 2) a $\mathrm{HCO}_{3}{ }^{*}$ concentration of $0.02 \mathrm{M}$ : and 3) that only the reaction in Equation (20) took place. He calculated that a maximum of $9 \times 10^{-7}$ mole $\mathrm{CO}_{2} / 1 \mathrm{sec}$ would be available for algal growth. He then considered that a 0.1 percent (by volume) concentration of algae would, under strong light conditions, be capable of photosynthesizing at a maximum rate of $3.3 \times 10^{-7}$ mole $\mathrm{CO}_{2} / 1$ sec. Thus almost three times more $\mathrm{CO}_{2}$ would be available than would be required for this concentration of 


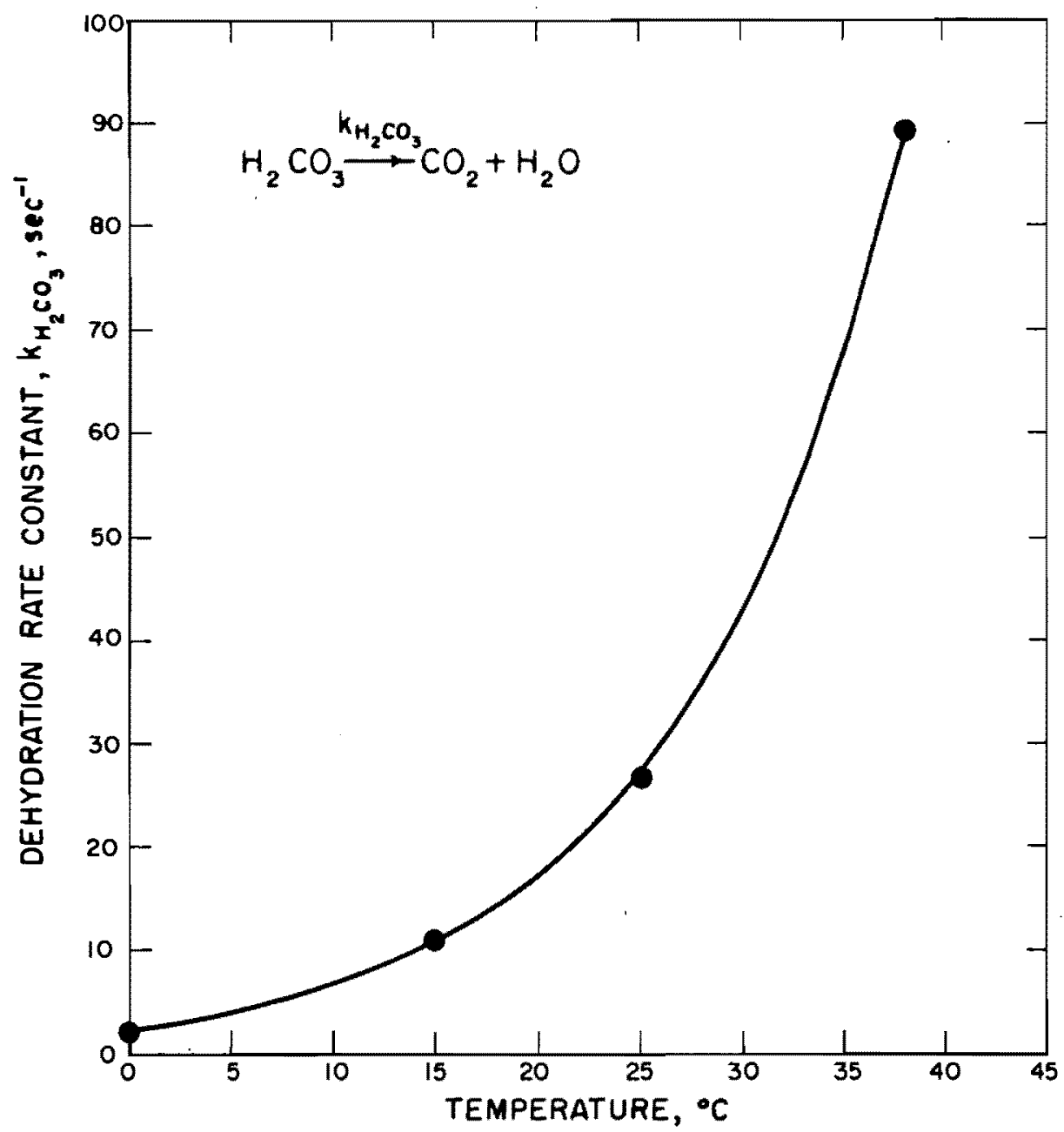

Figure 7. Effect of temperature on dehydration rate constant for carbonic acid.

algae. It could be argued that the numbers used by Rabinowitch for these calculations are completely unrealistic when applied to a typical bloom condition in an eutrophic natural water. In order to show that Rabinowitch's calculation was actually conservative when applied to a bloom condition in a eutrophic water a similar calculation will be made based on the following assumptions:

(1) That the total bicarbonate alkalinity as $\mathrm{CaCO}_{3}$ is equal to $50 \mathrm{mg} /$;

(2) That the bloom has already progressed to the point where the $\mathrm{pH}$ has been raised to 10 , where $\mathrm{CO}_{2}$ is derived from $\mathrm{HCO}_{3}{ }^{-}$directly (Equation (20));

(3) That the algal concentration, $X$, at this point in the bloom is $50 \mathrm{mg} / \mathrm{l}$; 
(4) That the specific growth rate of the algae, $\mu$, is 0.3 day $^{-1}$; and

(5) That the carbon content of the algal cells is 50 percent of the total algal dry weight.

Thus the change in algal concentrates per unit time, $\mathrm{dX} / \mathrm{dt}$, can be described as

$$
\frac{\mathrm{dX}}{\mathrm{dt}}=\mu \mathrm{X}=15 \mathrm{mg} \cdot 1^{-1} \cdot \mathrm{day}^{-1}=1.74 \times 10^{-4} \mathrm{mg} \cdot 1^{-1} \cdot \mathrm{sec}^{-1}
$$

and the change in carbon, $\mathrm{C}$, per unit time transformed into algal biomass is

$$
\frac{\mathrm{dC}}{\mathrm{dt}}=0.5(\mu \mathrm{x})=8.7 \times 10^{-5} \mathrm{mg} \cdot 1 \cdot \mathrm{sec}^{-1}
$$

Converting the carbon content to an equivalent molar concentration of bicarbonate, $\left(\mathrm{HCO}_{3}{ }^{-}\right)$

$$
\frac{\mathrm{d}\left(\mathrm{HCO}_{3}{ }^{-}\right)}{\mathrm{dt}}=7.24 \times 10^{-9} \mathrm{moles} \cdot 1 \cdot \mathrm{sec}^{-1} \text {.. }
$$

Fifty $\mathrm{mg} / \mathrm{l}$ of $\mathrm{CaCO}_{3}$ alkalinity equals $61 \mathrm{mg} / \mathrm{l}$ of $\mathrm{HCO}_{3}^{-}$alkalinity, or $1 \times 10^{-3} \mathrm{M}$ of $\mathrm{HCO}_{3}{ }^{-}$. Thus, using Rabinowitch's value of $0.47 \times 10^{-4} \mathrm{sec}^{-1}$ for the dehydration rate constant, the ratio of carbon dioxide available to carbon dioxide utilized at $25^{\circ} \mathrm{C}$ is approximately $6: 1$. With Kern's dehydration rate constant of $2 \times 10^{-4} \mathrm{sec}^{-1}$ the ratio is approximately $28: 1$. Under the conditions described the dehydration step is definitely not rate limiting. These calculations are very crude because other than the arbitrary nature of the values chosen no accounting was made for temperature and activity affects, nor was carbon dioxide diffusion from the atmosphere considered. However, the values chosen would constitute a severe algal bloom situation (e.g. Mackenthun et al., 1968). Also it was assumed that the pH had already reached 10 . Most blooms start at a considerably lower $\mathrm{pH}$ value when the faster dehydration reaction, $\mathrm{H}_{2} \mathrm{CO}_{3}+\mathrm{CO}_{2}+\mathrm{H}_{2} \mathrm{O}$, would predominate. The lower $\mathrm{pH}$ values would make more $\mathrm{HCO}_{3}^{-}$readily available for conversion to $\mathrm{CO}_{2}$ than indicated by the calculation for a $\mathrm{pH}$ value of 10 .

Another important factor which strengthens the argument against $\mathrm{H}_{2} \mathrm{CO}_{3}$ dehydration being a rate-limiting step for carbon utilization by growing algae in a bloom condition is the presence of the enzyme carbonic anhydrase which catalyzes the dehydration reaction.

\section{The role of the enzyme carbonic anhydrase}

Carbonic anhydrase is the enzyme responsible for catalyzing the dehydration of $\mathrm{H}_{2} \mathrm{CO}_{3}$ during human respiration (Meldrum and Roughton, 1933). Edsall and Wyman (1958) have reported that carbonic anhydrase has a very high activity, being able to double the rate of dehydration of $\mathrm{H}_{2} \mathrm{CO}_{3}$ when present in minute concentrations of $1 \mu \mathrm{g} / \mathrm{l}$ or less. While its role in human respiration is quite well defined, little information is available on how it affects $\mathrm{H}_{2} \mathrm{CO}_{3}$ dehydration in algal systems. Both Steemann Nielsen and Kristiansen (1949) and Osterlind (1950b) tried to explain the direct utilization of $\mathrm{HCO}_{3}{ }^{-}$in certain aquatic plants and algae by demonstrating a lack of this enzyme. However, this enzyme was found in all the species they examined, regardless of the species' ability to use $\mathrm{HCO}_{3}{ }^{-}$, and they could not draw 
positive conclusions regarding its role. Litchfield and Hood (1964) demonstrated that the enzyme was present in 11 fresh water and marine algae. They showed that the renzyme was located within the soluble portions of the inner cell and that heating had an adverse affect on activity. Nelson et al. (1969) found that the carbonic anhydrase concentration in Chlamydomonas was 20 times greater when the cells were grown on 0.03 percent $\mathrm{CO}_{2}$ as compared to 1 percent $\mathrm{CO}_{2}$. This suggests that carbonic anhydrase participation in the dehydration of $\mathrm{H}_{2} \mathrm{CO}_{3}$ becomes more important when the $\mathrm{pH}$ of an algal system not at equilibrium with atmospheric $\mathrm{CO}_{2}$ increases. The $\mathrm{H}_{2} \mathrm{CO}_{3}$ is readily derived from the ionic inorganic forms, but also the enzyme may mediate the direct dehydration of $\mathrm{HCO}_{3}{ }^{-}$via Equation (20).

While there is no direct evidence that the enzyme is extracellular, Berger and Libby (1969) suggested that the presence of this enzyme in the oceans could be a significant factor in equilibrating atmospheric $\mathrm{CO}_{2}$ with the $\mathrm{CO}_{2}$ content of sea water. Also, Krishnamurty (1969) reported the possibility of metal carbonate complexes aiding in this enzymatic process. Forster and Edsall (1969) reviewed a recent conference on the chemical, biological, and physiological aspects of $\mathrm{CO}_{2}$ and stated that $\mathrm{CO}_{2}$ dissolved most readily in solvents such as acetone. These compounds contain both hydrophobic and polar groups. Enzymes such as carbonic anhydrase could have a similar effect on $\mathrm{CO}_{2}$ which could help in explaining their effect on the kinetics of $\mathrm{CO}_{2}$ assimilation by algae.

It is known that zinc is required for activiation of carbonic anhydrase (Edsall and Wyman, 1958). Riepe and Wang (1967) partially explained the role of zinc with the hypothesis that $\mathrm{HCO}_{3}{ }^{-}$is dehydrated to $\mathrm{CO}_{2}$ when there is a breaking of a $\mathrm{C}$ - $\mathrm{O}$ bond in $\mathrm{HCO}_{3}-$. A resulting proton transfer causes an $\mathrm{OH}^{-}$to be coordinated to $\mathrm{Zn}{ }^{+}$with the result that the $\mathrm{OH}^{-}$is separated from the enzyme.

What specific role the enzyme has in relation to the uptake of inorganic carbon by algae in natural waters still remains to be answered. The very fact that its presence has been demonstrated in many algal systems suggests that it is intimately involved in providing carbon for algal growth when the free $\mathrm{CO}_{2}$ content of a water is low. However, it would appear that to be effective in the uptake of inorganic carbon the carbonic anhydrase would have to operate externally to the cell. Further research on this aspect of inorganic carbon utilization is necessary. 


\section{CARBON UTILIZATION BY ALGAE}

The photosynthetic reaction described in Equation (1) shows the formation of a carbohydrate product which represents a carbon content, on a dry weight basis, of over 50 percent. Generally, most values given in the literature indicate a carbon content for algal cells very close to this value. Ketchum (1954) reported values of 51 to 56 percent for various algae grown under continuous illumination. Parsons et al. (1961) showed a range from 15.9 to 53.2 percent for a variety of marine phytoplankton. Thus, the reported carbon content of various freshwater and marine algae does vary (Table 3 ). This variation is a frunction of the species and the environment of cultivation.

\section{Sources of Carbon}

$\mathrm{CO}_{2}, \mathrm{HCO}_{3}{ }^{-}, \mathrm{CO}_{3}{ }^{-}$, and organic compounds can all serve as the source of carbon for algae under specific conditions. Under normal conditions where free $\mathrm{CO}_{2}$ is available it is often the preferred form of carbon used by the photoautotrophic algae (Myers, 1951). A number of researchers indicate that bicarbonates and carbonates may also be used directly (Holm-Hansen, 1967). Also, there is extensive information to support the notion that heterotrophic and chemotrophic activity by algae is widespread.

\section{Organic carbon utilization by algae}

Many phytoplankton algae exhibit heterotrophic, chemotrophic, and autotrophic types of metabolism (Ketchum, 1954). Some species may exhibit all three metabolic types under appropriate conditions. Chemotrophic assimilation of carbon by algae has been discussed by Bristol-Roach (1926, 1927), Barker (1935), Pearsall and Bengry (1940), Doyle (1943), Algeus (1946), Hunter and Provasoli (1951), Myers (1951), Fogg (1953), Lewin (1963).

Myers (1951) reported that although many researchers had shown heterotrophic growth of algae through the addition of organic carbon, none was able to demonstrate that this growth occurred when $\mathrm{CO}_{2}$ was not limiting. With adequate $\mathrm{CO}_{2}$ it appears that the photosynthetic mechanism is the predominant one. Lange (1967) suggested that organic matter converted to $\mathrm{CO}_{2}$ through bacterial respiration enhanced algal activity, and that this process was a major factor related to algal blooms in natural waters. However, his work was performed under conditions of relatively high nutrient and low $\mathrm{CO}_{2}$ concentrations and was not comparable to natural conditions nor to a control where $\mathrm{CO}_{2}$ was added in excess. 
Many other workers have demonstrated both the uptake and release of organic carbon compounds by algae (Ward et al., 1964, Fogg, 1965, Fogg et al., 1965, Ward and Moyer, 1966, Vaccaro and Jannasch, 1967, Smith et al., 1968a, 1968b, Litch-

Table 3. Variation in carbon content of algal cells of various species.

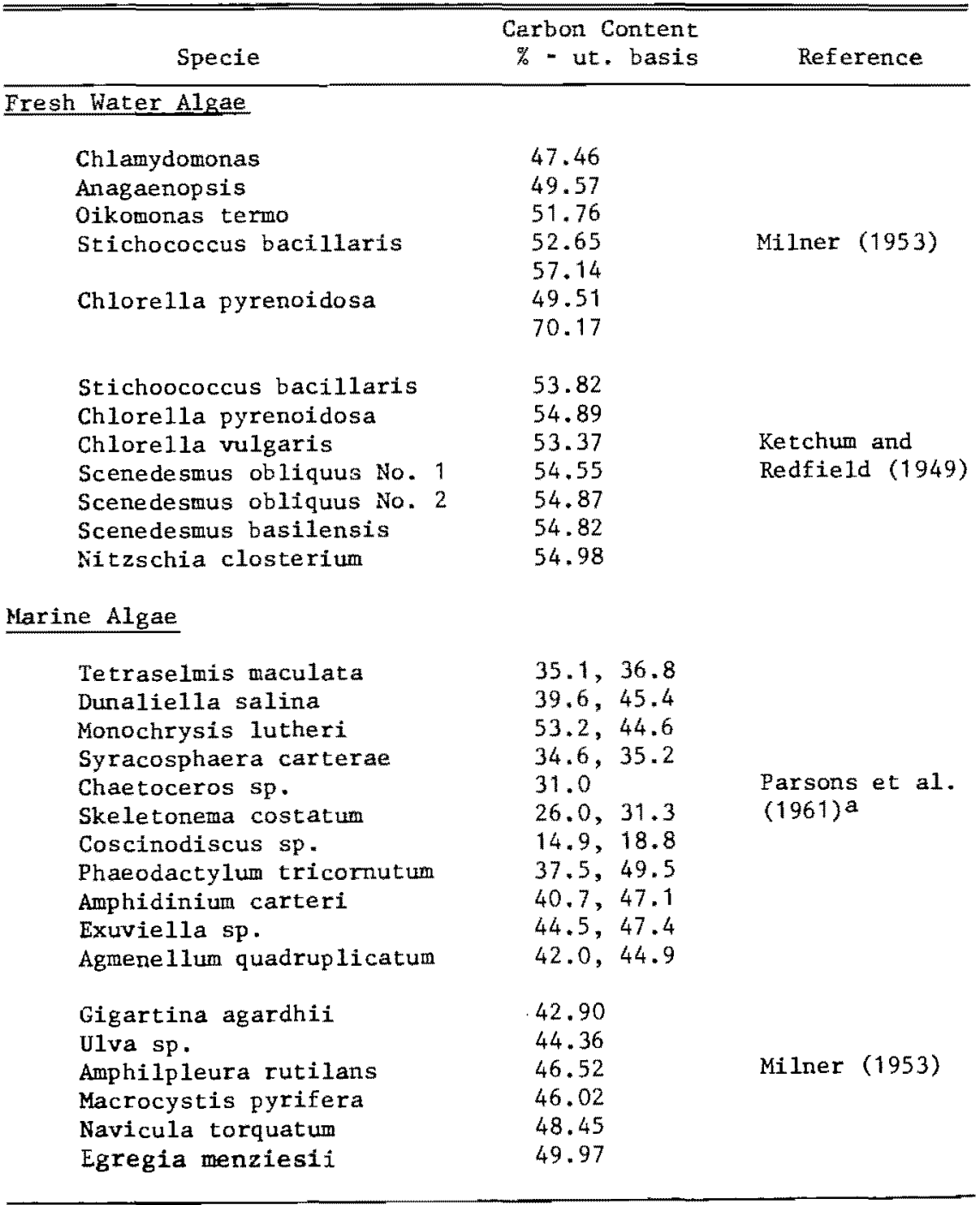


field et al., 1969). Fogg (1965) and Fogg et al. (1965) showed that glycolic acid was a major excretory product of phytoplankton and that production of this acid increased under high light intensity and carbon dioxide deficiences. Glycolic acid could be used as a carbon source by bacteria and algae and thus could be a carbon source in the regeneration of $\mathrm{CO}_{2}$ for photosynthetic growth. This concept suggests that a portion of the $\mathrm{CO}_{2}$ utilized by algae during bloom conditions is actually derived from bacterial activity. This $\mathrm{CO}_{2}$ may be cycled or introduced from organic carbon sources (breakdown of allochthonous material, dissolved organics, decay of autochthonous production). Kuentzel (1969) presented the hypothesis that bacterial production of $\mathrm{CO}_{2}$ is the major causative factor in many algal blooms. Although Kuentzel's argument was based primarily on the work of Lange (1967), he failed to acknowledge the significance of other sources of inorganic carbon, primarily atmospheric $\mathrm{CO}_{2}$ and bicarbonate. Also no mention was made of the apparent ability of certain algae to utilize the $\mathrm{HCO}_{3}$ : directly.

Smith et al. (1960) reported that complexed $\mathrm{CO}_{2}$ in carbamino carboxylic acids was more readily available for assimilation by algae than was dissolved $\mathrm{CO}_{2}$. Steemann Nielsen (1963) criticized this on the basis that under the conditions of the experiment, ${ }^{14} \mathrm{CO}_{2}$ assimilation was inhibited, not by the preferential use of $\mathrm{CO}_{2}$ from the complex, but rather by the release of $\mathrm{NH}_{3}$ from the complex at the high $\mathrm{pH}$ values experienced; the $\mathrm{NH}_{3}$ thus released could act as a poison to affect cell metabolism.

The significance of the role of organic carbon compounds in the occurrence of algal blooms following cultural eutrophication is at present uncertain, as evidenced by the many conflicting reports in the literature. Careful consideration will be given to the utilization of inorganic carbon by algae because the use of this form of carbon by photosynthesizing algae is better understood and it obviously has a significant role in algal growth during the eutrophication process.

\section{Inorganic carbon utilization by algae}

The early work on inorganic carbon utilization by algae from the late 1930's through the early 1950 's was performed by researchers investigating the phenomena governing the photosynthetic mechanism. The main theme of this work was to determine which forms of carbon preferentially stimulated algal growth. At this time eutrophication was an unrecognized problem in world wide terms.

As mentioned previously in this paper, $\mathrm{CO}_{2}$ activity rather than concentration would provide more accurate interpretation of results especially for some of the high nutrient concentrations which are used as culture media. None of the investigations described in this section have measured the activity of the chemical constituents described and thus the results cannot be utilized unequivocally. Although the results are not invalidated, activity of nutrients should be considered in such investigations as one might suspect that growth rates (e.g. see Monod, 1949) would be a function of activity rather than molar concentrations. Perhaps, the advent of selective ion electrodes will help in further investigations.

Emerson and Green (1938) working with Chlorella, a favorite test alga of early researchers, found in manometric studies that saturation with $\mathrm{CO}_{2}$ in concentrations 
ranging from 0.05 percent to 5 percent of atmospheric air caused little change in the rate of photosynthesis over a $\mathrm{pH}$ range from 4.6 to 8.9 . These results were criticized by Steemann Nielsen (1952) on the basis that allowances were not made for carbon reserves present in the algae cells at the start of the experiment.

In a most convincing series of experiments Osterlind $(1949,1950 \mathrm{a}, 1950 \mathrm{~b})$ and Steemann Nielsen $(1951,1952,1953,1955 \mathrm{a}, 1963)$ demonstrated that $\mathrm{HCO}_{3}{ }^{-}$was preferred by Scenedesmus; whereas dissolved $\mathrm{CO}_{2}$ was the only inorganic carbon source available to certain other species, notably Chlorella. These and other results were reviewed quite thoroughly by Fogg (1953) in his monograph on algal metabolism and by Rabinowitch $(1945,1951,1956)$ in his three volume treatise on photosynthesis. Osterlind $(1949,1950 \mathrm{a}, 1951 \mathrm{a})$ demonstrated that Chlorella was capable of utilizing only dissolved $\mathrm{CO}_{2}$ while young $S$ cenedesmus cultures could utilize both dissolved $\mathrm{CO}_{2}$ and $\mathrm{HCO}_{3}{ }^{\circ}$ and seemed to utitize the latter more effectively. Old Scenedesmus cultures lost their ability to utilize $\mathrm{HCO}_{3}{ }^{-}$and showed a response similar to Chlorella. Further experiments (1950b) showed that there was little difference in the concentration of the enzyme, carbonic anhydrase, responsible for dehydration of $\mathrm{H}_{2} \mathrm{CO}_{3}$ in both groups of algae, leading Osterlind to the conclusion that a true utilization of $\mathrm{HCO}_{3}{ }^{\circ}$ by Scenedesmus took place. Osterlind (1951b) later proposed the theory that young $S$ cenedesmus uniquely possessed an enzyme system which upon "photoactivation" catalyzed direct $\mathrm{HCO}_{3}$ " utilization. Activation either took place at the cell wall surface or within the cell itself with the enzyme in the latter case being simply carbonic anhydrase.

Briggs and Whittingham (1952) substantiated Osterlind's claim that Chlorella could only utilize dissolved $\mathrm{CO}_{2}$. Steemann Nielsen (1952) working with higher aquatic plants demonstrated a similar action in certain species. He showed a definite utilization of $\mathrm{HCO}_{3}$ " on one side of an aquatic leaf and liberation of $\mathrm{OH}^{-}$ions on the other side according to the equation $\mathrm{HCO}_{3}{ }^{-}=\mathrm{OH}^{-}+\mathrm{CO}_{2}$. He later presented evidence (Steemann Nielsen and Jensen, 1958) that the $\mathrm{HCO}_{3}{ }^{-}$was capable of penetrating the Chlorella cell surface but that the rate of this penetration was so low as to be insignificant. Felfoldy (1960a) demonstrated $\mathrm{HCO}_{3}{ }^{-}$utilization by Chlorella but noted that utilization occurred only after long periods of adaptation. He also indicated there was a possible direct utilization of $\mathrm{CO}_{3}{ }^{-}$by certain algae at very high $\mathrm{pH}$ values although no concrete evidence to support this notion was presented (1960b).

Later attempts by Hood and Park (1962) to show that certain marine phytoplankton including a marine Chlorella sp. could also utilize $\mathrm{HCO}_{3}{ }^{-}$were severely criticzed by Watt and Paasche (1963) and by Steemann Nielsen (1963). Hood and Park claimed that, aside from respiratory $\mathrm{CO}_{2}$ production, $\mathrm{CO}_{2}$ derived from the dehydration of $\mathrm{H}_{2} \mathrm{CO}_{3}$ and from diffusion of atmospheric $\mathrm{CO}_{2}$ were the only sources of carbon available to algae for autotrophic growth. They felt that diffusion from the atmosphere was so slow as to be an insignificant source of carbon. Also they made the claim that dehydration was slow enough to likewise cause carbon limitations. On the basis of the latter hypothesis they purported to show that $\mathrm{HCO}_{3}{ }^{-}$was the main source of carbon for certain algal species at very low dissolved $\mathrm{CO}_{2}$ concentrations. Both Watt and Paasche (1963) and Steemann Nielsen (1963) showed by theoretical and experimental work that the "slow hydration rate" was indeed fast enough to prevent distinguishing between $\mathrm{CO}_{2}$ and $\mathrm{HCO}_{3}{ }^{-}$utilization. Thus no valid conclusions could be drawn from Hood and Park's work. Briggs (1959) 
claimed that in certain instances the apparent direct utilization of $\mathrm{HCO}_{3}{ }^{-}$could really be explained by its affect on the $\mathrm{CO}_{2}$ concentration at the point where consumption was taking place. $\mathrm{HCO}_{3}{ }^{-}$was thus acting solely as a reservoir for $\mathrm{CO}_{2}$. Paasche $(1963,1964)$ in other work showed that coccolith formation in the coccolithophorid Coccolithus huxleyi resulted solely from utilization of $\mathrm{HCO}_{3}{ }^{*}$. The rate of photosynthesis, on the other hand, was a function of $\mathrm{HCO}_{3}{ }^{-}$and/or the dissolved $\mathrm{CO}_{2}$ present. Steemann Nielsen (1966) further amplified these conclusions by showing that a naked clone of the same specie utilized only $\mathrm{CO}_{2}$ for photosynthesis but that $\mathrm{HCO}_{3}{ }^{-}$was made directly available through the coccolith formation mechanism. Swift and Taylor (1966) showed an optimum $\mathrm{pH}$ of 7.8 for cell division of the coccolithophorid Cricosphaera elongata.

Witt and Borchardt (1960) and Gates and Borchardt (1964) working with continuous algal cultures showed that when the $\mathrm{CO}_{2}$ supply was turned off to a relatively small concentration of growing Scenedesmus the $\mathrm{pH}$ rose from 8.3 causing an immediate lag phase in the production rate while the algae readjusted to using $\mathrm{HCO}_{3}{ }^{-}$as their source of carbon. After this readjustment the production rate continued as before until the culture failed at a $\mathrm{pH}$ of 10 . In a similar experiment with a much more concentrated culture of Scenedesmus no lag phase occurred when the $\mathrm{CO}_{2}$ supply was stopped and the algae had to convert to using $\mathrm{HCO}_{3}{ }^{-}$. The authors explained this occurrence by stating that with the low algal concentration carbon never was limiting and the algae were using only dissolved $\mathrm{CO}_{2}$ before the supply was stopped. In the latter case carbon was limiting even before the $\mathrm{CO}_{2}$ supply was stopped and the algae were forced to use both dissolved $\mathrm{CO}_{2}$ and $\mathrm{HCO}_{3}$. No adjustment was thus necessary for conversion to $\mathrm{HCO}_{3}{ }^{-}$once the $\mathrm{CO}_{2}$ supply was removed. However, Soltero and Lee (1967), demonstrating an automatic pH control device for algal cultures, gave evidence that at a $\mathrm{pH}$ of 7 optimum growth of Scenedesmus occurred.

This was in contrast to the work of Witt and Borchardt (1960) and Gates and Borchardt (1964) who could show little change in the growth of Scenedesmus over a wide $\mathrm{pH}$ range although best growth was observed at a $\mathrm{pH}$ of 8.3 . A possible explanation for these differences might be that Witt, Gates, and Borchardt used wastewater treatment plant effluent for their substrate in which the total alkalinity was $120 \mathrm{mg} / \mathrm{l}$ (as $\mathrm{CaCO}_{3}$ ), while Soltero and Lee used a synthetic medium in which the bicarbonate alkalinity was $21 \mathrm{mg} / 1$ (as $\mathrm{CaCO}_{3}$ ). Thus, the apparent difference in optimum $\mathrm{pH}$ for growth of Scenedesmus might be accounted for by the fact that in the case of Soltero and Lee, little $\mathrm{HCO}_{3}$ - was available over the entire $\mathrm{pH}$ range, and that as the $\mathrm{pH}$ was lowered more carbon in the form of $\mathrm{CO}_{2}$, which could also be used by the Scenedesmus, was present since $\mathrm{pH}$ adjustment was controlled through $\mathrm{CO}_{2}$ addition. At a $\mathrm{pH}$ of 6 , however, less growth was observed. Although more dissolved $\mathrm{CO}_{2}$ would be present at a $\mathrm{pH}$ of 6 , the poorer growth at this $\mathrm{pH}$ value as compared to that at a pH of 7 possibly could be explained by an adverse physiological effect on the algae of this lower pH. In the case of Witt, Gates, and Borchardt the high alkalinity contributed the maximum amount of $\mathrm{HCO}_{3}{ }^{-}$at a $\mathrm{pH}$ of 8.3 , which is the point in the $\mathrm{CO}_{2}$ equilibrium system where essentially all the inorganic carbon is $\mathrm{HCO}_{3}{ }^{-}$. Thus, the algae were utilizing primarily $\mathrm{HCO}_{3}{ }^{-}$and growing best at this $\mathrm{pH}$. Brown (1969) growing algae on agricultural drainage water in cultures in which the pH was controlled with "Good" organic acid buffers (Good et al., 1966), and which had a total alkalinity of $350 \mathrm{mg} / \mathrm{l}\left(\mathrm{as} \mathrm{CaCO}_{3}\right.$ ), achieved best growth at a $\mathrm{pH}$ of 8.4 (as 
compared to other tested $\mathrm{pH}$ values of $6.15,7.5$, and 10.5). His results are in close agreement with those obtained by Witt, Gates, and Borchardt.

In most of the experiments dealing with carbon effects on Chlorella it was found that a $\mathrm{CO}_{2}$ concentration of from 0.01 to 0.03 percent was adequate for maintaining the maximum rate of photosynthesis (Emerson and Green, 1938, Briggs and Whittingham, 1952, Steemann Nielsen, 1953, 1955a). Since approximately 0.03 percent $\mathrm{CO}_{2}$ is found in atmospheric air, sufficient carbon for maximum photosynthesis of Chlorella should be present when a culture is exposed to and in equilibrium with atmospheric $\mathrm{CO}_{2}$. Obviously then for most culture devices in which little or no turbulent mixing is maintained, carbon is extracted from solution at a faster rate than it can diffuse into solution from the atmosphere. A carbon limitation is then created, placing an upper limit on the rate of photosynthesis.

The term "rate of photosynthesis" refers to the rate at which a given algal cell produces oxygen or fixes carbon dioxide, while the term "rate of growth," refers to the rate of algal mass produced or the more commonly used term "specific growth rate," refers to the rate of algal mass production per cell concentration.

The percent $\mathrm{CO}_{2}$ in air is a relatively meaningless term in trying to describe the amount of $\mathrm{CO}_{2}$ required for maximum photosynthesis in culture work if no accounting is made for the concentration of $\mathrm{CO}_{2}$ in solution which is really available to the algae. The amount really dvailable is a function of the sparging rate and its effect on the $\mathrm{CO}_{2}$ tension.

Steemann Nielsen (1955a) in referring to the high $\mathrm{CO}_{2}$ concentrations $(0.2$ 1.0 percent) required by Osterlind (1951a) and by Rosenberg (1954) to achieve maximum photosynthetic rates with Scenedesmus and Chlorella claimed that in both cases a dense algal concentration caused enough competition for the available carbon so that maximum photosynthetic rates could be measured only at these high $\mathrm{CO}_{2}$ concentrations. Thus, the cultures were actually carbon limited at the low $\mathrm{CO}_{2}$ concentrations and no true measurements of maximum photosynthetic rates were possible.

Rosenberg (1957) answered Steemann Nielsen's criticism by stating that $\mathrm{CO}_{2}$ limitations were only important under high light intensities. With dense algal cultures the effect of light shading should have caused even greater carbon limitations than he observed. He did point out, however, that discrepancies among researchers as to optimum $\mathrm{CO}_{2}$ concentrations for maximum photosynthesis might be explained by the fact that long adaptation periods seem to be required when switching from high to low $\mathrm{CO}_{2}$ concentrations. Rosenberg's experiments only lasted for minutes, which might explain his failure to note high photosynthetic rates at low $\mathrm{CO}_{2}$ concentrations. Steemann Nielsen and Willemoes (1966) did not observe any differences in the photosynthetic rate of Chlorella with either air or 5 percent $\mathrm{CO}_{2}$ in air as the carbon source.

Myers (1953) reported that $\mathrm{CO}_{2}$ concentrations between 0.1 and 5 percent were adequate to prevent the growth rate from becoming carbon limited. It appears from the various reports reviewed on the subject of $\mathrm{CO}_{2}$ concentration in algae cultures that often optimum levels of $\mathrm{CO}_{2}$ for maximum photosynthetic rates and 
for maximum growth rates are claimed to be the same (Steemann Nielsen, 1955a). Obviously the required concentration of carbon dioxide in solution is a function of the desired algal production, the denser the culture, the more $\mathrm{CO}_{2}$ required. Myers (1953) states that a 5 percent $\mathrm{CO}_{2}$ concentration is adequate for growth situations in which the $\mathrm{CO}_{2}$ uptake is high, and as a result there is a large diffusion gradient between the culture and the gas phase. The 5 percent $\mathrm{CO}_{2}$ added will maintain enough $\mathrm{CO}_{2}$ in solution so that carbon is not limiting. Davis et al. (1953) substantiated Myers' claim and found no difference in algal growth rate at $\mathrm{CO}_{2}$ concentrations in air from 0.56 to 4.43 percent.

Based upon the work of Myers (1953), Davis et al. (1953), and other researchers who contributed to the classic Carnegie Institute publication on the mass culturing of algae, most subsequent studies on algae culturing indicate that $\mathrm{CO}_{2}$ concentrations from 1 to 5 percent are adequate. The work of Pipes and Koutsoyannis (1962) and Miller (1968) are representative examples.

Myers (1953), Steemann Nielsen (1953,1955a), Fogg and Than-Tun (1960, 1965) have all reported toxic effects at high $\mathrm{CO}_{2}$ concentrations. Myers and Fogg (1953) claimed that $\mathrm{CO}_{2}$ concentrations over 5 percent were to be avoided. Steemann Nielsen (1953) showed that in saturated light, $\mathrm{CO}_{2}$ concentrations greater than 1 percent were toxic, while in unsaturated light $\mathrm{CO}_{2}$ assimilation rates increased at $\mathrm{CO}_{2}$ concentrations greater than 1 percent. Further work by Steemann Nielsen (1955a) demonstrated that under certain saturated light conditions, $\mathrm{pH}$ affected $\mathrm{CO}_{2}$ assimilation as a function of $\mathrm{CO}_{2}$ concentration. Lower $\mathrm{pH}$ values tended to give increasing $\mathrm{CO}_{2}$ assimilation rates for $\mathrm{CO}_{2}$ concentrations greater than 1 percent. Fogg and Than-Tun (1960) and Fogg (1965) have demonstrated the existence of a toxic effect on a blue-green alga, Anabaena, at a $\mathrm{CO}_{2}$ concentration over 1 percent. However, Tew et al. (1962) in trying to reduce volume requirements for a photosynthetic gas exchanger for space application by utilizing 100 percent $\mathrm{CO}_{2}$ as the carbon source, were able to sustain a culture for a considerable period of time by providing the $\mathrm{CO}_{2}$ at a flow rate corresponding to the algae production rate such that all the carbon was assimilated. Although the unit eventually failed, the authors attributed this failure to the physical design of the continuous culture device and not necessarily to any toxic effects resulting from the use of 100 percent $\mathrm{CO}_{2}$.

Pipes (1962a) along with Tew et al. (1962) have performed the only meaningful experiments in the United States with continuous cultures which describe the kinetic relationships of carbon dioxide limited growth of Chlorella. Pipes, using the kinetic growth model for chemostatic cultures proposed by Monod (1950) and Novick and Szilard (1950), and reviewed in detail by Herbert, Elsworth, and Telling (1956), showed that when a constant supply of $\mathrm{CO}_{2}$ is provided the algal production rate within a range of dilution rates (or residence times) was independent of the dilution rate and linearly proportional to the rate of $\mathrm{CO}_{2}$ supply (by doubling the flow rate of a fixed concentration of $\mathrm{CO}_{2}$-enriched air the algal production rate was doubled).

In Czechoslovakia extensive work by the Institute of Microbiology of the Czechoslovak Academy of Sciences on the mass culturing of algae has been in progress for a number of years (Setlik et al., 1966, Annual Report, 1967, 1968). A major concern has been the solution to problems associated with carbon limitations on 
growth. Various techniques for efficiently supplying $\mathrm{CO}_{2}$ have been investigated. Work in Russia dealing with carbon effects on algal growth also is reported in the literature (Levshina, 1965, Semenenko, 1966).

\section{Carbon Utilization in Special Systems}

The incorporation of carbon by algae in the aquatic environment occurs in three general systems: wastewater treatment systems such as oxidation ponds, natural water bodies (i.e. the oceans, lakes, impoundments, rivers, etc.), and controlled laboratory facilities (e.g. batch and chemostat experiments). In natural systems, visible concentrations of algae are usually undesired and when present in sufficient numbers constitute a nuisance condition leading to serious impairment of beneficial uses of the waters. In the treatment systems the growth of algae is encouraged since treatment efficiency is dependent on the oxygen supplied by photosynthetic organisms. In both natural and waste treatment systems the introduction of chemical nutrients induces algal growth which will be limited by the one factor in shortest supply. It appears from reports in the literature that carbon is often the growth limiting nutrient in oxidation ponds but that its role as a limiting nutrient for algal growth in natural waters is not as well documented.

\section{Wastewater treatment systems}

In the early work performed at the University of California in developing algal-bacterial systems for wastewater treatment, studies (Ludwig et al., 1951) dealing with the algae species Euglena showed that the addition of supplementary $\mathrm{CO}_{2}$ to a settled, sterilized sewage medium had a positive effect on cell concentration and yield. The addition of air enriched with 2.3 percent $\mathrm{CO}_{2}$ increased the cell concentration and yield considerably as compared to the addition of atmospheric air $(0.03$ percent $\mathrm{CO}_{2}$ ). This study indicated that carbon might be the growth limiting factor for sewage-grown algae. Other studies in this research endeavor confirmed the suspicion that the lack of carbon had limited algal growth in oxidation ponds (Oswald et al., 1953a, 1953b). Further work by Oswald (1963) demonstrated that maximum light conversion efficiencies were obtained with $\mathrm{CO}_{2}$ at a concentration of 1 to 2 percent. However, nitrogen was depleted at a $\mathrm{CO}_{2}$ concentration of 2 percent and thus became limiting in cultures grown in higher $\mathrm{CO}_{2}$ concentrations. It is possible that even greater efficiencies would have been attained at the higher $\mathrm{CO}_{2}$ concentrations had enough nitrogen been provided.

Although the work at the University of California was the first to elucidate the need for supplementary carbon in waste treatment systems, other researchers have since reached a similar conclusion. Studies by Allen (1955) on algal growth with sewage effluents demonstrated a marked increase in growth when 5 percent $\mathrm{CO}_{2}$ was bubbled through the cultures. Allen noted that both Chlorella and Scenedesmus were the prominent algae species found in stabilization ponds and that, while in batch cultures, Chlorella would at first be the predominant species, it was superceded by Scenedesmus. Although Allen did not offer an explanation for this particular succession, it would seem that results obtained in the work of Osterlind, Steemann Nielsen and others on the preferential use of $\mathrm{HCO}_{3}{ }^{-}$as a carbon source for Scenedesmus, as compared to that for Chlorella, offer a logical explanation for this changeover. Since Allen's cultures were experiencing a $\mathrm{pH}$ rise (up to values of 8 to 10, levels at which 
the predominant carbon form is $\mathrm{HCO}_{3}$ ), the possibility exists that Scenedesmus replaced Chlorella due to its ability to utilize $\mathrm{HCO}_{3}{ }^{-}$directly.

Meffert (1955) working with algae grown on sewage also added $\mathrm{CO}_{2}$ to improve algal growth, although her reasoning for this action is open to question. She claimed that because $\mathrm{CO}_{2}$ production from bacterial respiration was not sufficient, a rise in $\mathrm{pH}$ resulted in the predominance of $\mathrm{HCO}_{3}{ }^{-}$and $\mathrm{CO}_{3}{ }^{-}$. The possibility that a simple carbon limitation existed which bacterial production of $\mathrm{CO}_{2}$ could not overcome, regardless of whether the Scenedesmus were utilizing $\mathrm{HCO}_{3}{ }^{-}$, as claimed by others was not explored. This limitation was possibly corrected once supplementary $\mathrm{CO}_{2}$ was added to the cultures.

In their work with algal nutrient removal systems for sewage effluents Fitzgerald (1961) and Fitzgerald and Rohlich (1962) showed that carbon usually becomes limiting before nitrogen, and that the addition of extra carbon as $\mathrm{CO}_{2}$ increased yields and shortened the time for nitrogen assimilation in batch cultures. Brown and Arthur (1969) achieved similar results in trying to remove nitratenitrogen from agricultural tile drainage through assimilation into algal cellular material. However, the drainage water also required phosphorus and iron additions. Bush et al. (1961) working with a continuous outdoor algal growth system added 8 percent $\mathrm{CO}_{2}$ in order to achieve optimum nutrient removal from sewage effluents.

Fitzgerald and Rohlich (1962) also demonstrated the effect of $\mathrm{CO}_{2}$ addition on the maintenance of phosphorus solubility in algal cultures by preventing the removal of the phosphorus through precipitation at elevated $\mathrm{pH}$ values. Bogan et al. (1960), Bogan (1961), and Hemens and Mason (1968) likewise demonstrated the relationship between rise in $\mathrm{pH}$ level and phosphorus removal in algal wastewater treatment systems.

Mattoni et al. (1967), working with integrated algal systems which included wastewater treatment, water reclamation and protein production, controlled $\mathrm{pH}$ through acid addition. They observed alkalinity losses in semi-continuous algal reactors which they attributed to ammonia assimilation by algae. Pipes (1962b) reported that a similar reaction took place in algal waste treatment ponds, but only at a relatively high initial $\mathrm{pH}$ and alkalinity. At a lower initial $\mathrm{pH}$ and alkalinity a reverse reaction occurred, with the alkalinity in the effluent being higher than in the influent, although in both cases the $\mathrm{pH}$ rose over the initial value. No hypothesis was offered to explain this phenomenon. Pipes and Gotaas (1960) also showed that Chlorella, using sewage as a substrate, utilized organic carbon as a carbon source and that this utilization became more pronounced when the inorganic carbon supply was limited. Residence time and hence age of cells appeared to be the contributing factor in the excretion of dissolved organic material by the algae. At a residence time less than 3 days a net decrease in dissolved organic material took place in the growth units, while at a residence time greater than 3 days excretion exceeded assimilation of organic material.

Both Witt and Borchardt (1960) and Gates and Borchardt (1964) in their studies on nitrogen and phosphorus removal from wastewater treatment plant effluents by the controlled culture of algae, realized the need for adding supplementary $\mathrm{CO}_{2}$. King (1970) has also shown the necessity of carbon supplementation in waste- 
water oxidation ponds. Beck et al. (1969) showed that $\mathrm{CO}_{2}$ addition was necessary for complete $\mathrm{NO}_{3}-\mathrm{N}$ assimilation by algae grown on agricultural tile drainage in the San Joaquin Valley of Central California.

\section{Natural water bodies}

Sawyer (1954) in an early paper suggested that algal blooms could be controlled through carbon limitation if atmospheric $\mathrm{CO}_{2}$ were the only source of inorganic carbon available to algae. However, as he pointed out, additional carbon from the alkalinity and from bacterial $\mathrm{CO}_{2}$ production provides an ample reservoir of inorganic carbon. Sawyer also recognized the importance of $\mathrm{pH}$ on algal growth, and mentioned that $\mathrm{pH}$ values up to almost 10 were observed in water bodies where algal growth was active.

Ketchum (1954) made a similar claim that carbon in natural waters was rarely, if ever, limiting. However, Steemann Nielsen (1955b) through his work on eutrophic Danish lakes, felt that high $\mathrm{pH}$ values resulting from $\mathrm{CO}_{2}$ assimilation would limit algal activity during summer conditions. Jackson (1964) stated that blue green algal blooms occurred only when the $\mathrm{pH}$ value was greater than 8.5 . He disagreed with the long held theory that blooms actually started at lower $\mathrm{pH}$ values and that a $\mathrm{pH}$ rise above 8.4 was only a consequence of the blonm condition and not a precipitating factor. He felt that blue green algae required an elevated $\mathrm{pH}$ value in order to proliferate. Since at a $\mathrm{pH}$ greater than 8.4 very little inorganic carbon is present as $\mathrm{CO}_{2}$, perhaps the blue greens utilize $\mathrm{HCO}_{3}{ }^{-}$(as claimed for Scenedesmus) or even $\mathrm{CO}_{3}^{-}$. He also felt that there might be a preferential use of dibasic orthophosphate $\left(\mathrm{HPO}_{4}{ }\right)$ ) over the monobasic form $\left(\mathrm{H}_{2} \mathrm{PO}_{4}{ }^{-}\right)$, since the former is essentially the only inorganic phosphate form present at a $\mathrm{pH}$ greater than 8.4 . He concluded by offering a possible solution for preventing blue green algae from blooming: By keeping a lake water well buffered or so low in ions that a $\mathrm{pH}$ of 8.4 is never reached, blue green algae would never have the proper environment required for their profuse growth. A recent Russian paper by Merezhko (1968) claimed that several blue green algae utilized $\mathrm{HCO}_{3}{ }^{-}$as the carbon source.

\section{Controlled laboratory facilities}

Gerloff, Fitzgerald, and Skoog (1952) working with the blue green alga Microcystis aeruginosa cultured in an unbuffered medium showed that maximum growth occurred at a $\mathrm{pH}$ of 10 . McLachlan and Gorham (1961) and McLachlan (1962) working with the same algal species, observed little change in growth in a pure culture over a $\mathrm{pH}$ range of 6.5 to 10 in a well-buffered medium. However, when they tried to grow this alga together with the green alga Scenedesmus at a pH of 7.4 they obtained less than one-third of the growth reached by the blue green alga in pure culture. Thus, there was a definite competitive effect at the lower $\mathrm{pH}$, indicating that only at the higher $\mathrm{pH}$ values would the blue green alga predominate. Eberly (1967), working with Oscillatoria agardhii, another blue green algae grown in batch cultures, reported that the cultures with the highest initial $\mathrm{pH}$ values (up to 10) reached the exponential phase earliest, but that all cultures eventually reached the same level of maximum biomass. Holm-Hansen (1967) raised the question that since most blue green algae grow best at the higher $\mathrm{pH}$ values (8-11), and since at a $\mathrm{pH}$ of 11 most of 
the carbon is in the form of $\mathrm{CO}_{3}{ }^{2}$, are the algae really utilizing this ion preferentially?

In a recent conference held in Berkeley, California, on eutrophication and biostimulation (Middlebrooks et al., 1969) the need was stressed in several papers for a more detailed and quantitative look at the role of $\mathrm{CO}_{2}$ in relation to the problems of algal blooms. McIntire (1969) developed a laboratory model of a riffle area of a natural stream with water provided by a spring-fed creek. He found that the addition of $\mathrm{CO}_{2}$ above that normally present in solution had a dramatic effect on algal growth at light intensities around 1000 foot-candles and greater. This would tend to indicate that either carbon was limiting at this high light intensity or else the addition of the $\mathrm{CO}_{2}$ suppressed the $\mathrm{pH}$ enough so that certain nutrient salts (phosphorus or iron?) became more soluble thus stimulating growth. Wright (1969) demonstrated that $\mathrm{CO}_{2}$ was the growth limiting factor for primary production in the Firehole River complex in Wyoming. Using the upstream-downstream $\mathrm{CO}_{2}$ measurement method as described by Odum (1956) for determining primary productivity, Wright showed that changes in the photosynthetic rate were directly related to changes in the $\mathrm{CO}_{2}$ content in the water along the stretch of river studied. He concluded by stating that streams receiving effluents with high organic loads could produce en ough $\mathrm{CO}_{2}$ through bacterial respiration to make this nutrient as important in causing algae blooms as any other nutrient.

The recent Provisional Algal Assay Procedures (1969) has stimulated a considerable amount of research into finding a suitable method for measuring the algae growth potential of a water body. In trying to develop a test with which the effect of one nutrient can be studied at a time it is important that all other nutrients be in excess. Porcella (1969) has shown the difficulty in trying to interpret data which indicate that more than one nutrient may be limiting at a given time. He found that a sizable increase in algal growth in continuous culture devices took place at a given phosphorus level when supplementary $\mathrm{CO}_{2}$ was added. In the unit without $\mathrm{CO}_{2}$ the $\mathrm{pH}$ was maintained around 10.3. Obviously $\mathrm{CO}_{2}$ was limiting in this case and not phosphorus. Pearson et al. (1969), in comparing the batch type assay with the continuous culture assay, purported to show that the former was characterized by a maximum specific algal growth rate four times greater than that of the latter, in deference to theoretical considerations which would indicate that an opposite effect should occur. On the basis of these results it was concluded that the batch test was unreliable. In Pearson et al. tests, nitrogen was supposed to be the grow th limiting factor. However, the maximum specific growth rate for the continuous culture test was around 0.2 day ${ }^{-1}$, considerably lower than theory would indicate for the type of organism and substrate tested, while the batch assay maximum growth constant was around 0.9 day $^{-1}$, a rate closer to a typical value. The question then arises, was nitrogen really limiting in the continuous culture test, and if not, could a lack of $\mathrm{CO}_{2}$ have caused this depressed growth constant? The continuous culture unit was closed to the atmosphere and relied upon slow air bubbling for agitation. The batch flasks, on the other hand, had a relatively large surface area to volume ratio (150 $\mathrm{m} \ell$ of medium in a $250 \mathrm{~m}$ l flask) and were continually swirled on a shaker table. Brown and Arthur (1969), as previously mentioned, demonstrated the effect of $\mathrm{CO}_{2}$ addition and culture volume to flask size on algal growth. It would appear then that the results obtained in the Pearson study are inconclusive and further refinement 
of the test procedures is in order so that there is assurance that only the nutrient of concern is truly limiting.

An important consideration in developing a standard algal assay procedure, which was not included in the original PAAP report, would be to have $\mathrm{pH}$ control through $\mathrm{CO}_{2}$ addition over the growing cultures. Since reproducibility is a desired product of such a test it would appear that $\mathrm{pH}$ control would be an essential requirement when trying to compare data from different laboratories. Galloway and Krauss (1961) demonstrated this point and indicated that aside from physiological changes in algae due to $\mathrm{pH}$ changes, optimal density measurements for growth determinations could be affected by precipitate formation, which in turn would be a function of $\mathrm{pH}$.

\section{Nutrient Utilization by Algae}

This discussion has been abbreviated because of the considerable literature available to the reader and because of the great variety of possible conditions which can exist. The list of critical (i.e, most likely to be limiting) nutrients was defined on the basis of an algal growth medium (Algal Assay Procedures, 1971) which can be used for culturing most phytoplankton (Table 4). Some of the cations (sodium, potassium, magnesium) and anions (chloride, sulfate) necessary as elements for algal growth in that medium are generally in plentiful supply in natural waters and thus have been excluded from the list. Obviously, there is considerable variation in the composition of natural waters and these estimates can only be a comparative guide. There are numerous stoichiometric formulas for the elemental composition of algae (e.g. Ketchum, 1954, Stumm and Morgan, 1962, McCarty, 1970) but as shown in Tables 5 and 6 , it is impossible to assign an exact elemental relationship to plant life in general. Moreover, within a single species of algae maintained under different environmental conditions, the elemental composition can be quite variable. For example, Porcella et al., 1970, have shown that the utilization of nitrogen and phosphorus per unit of cells produced in batch cultures of Selenastrum capricornutum varies by a factor of 5 for nitrogen and 30 for phosphorus for conditions of high growth rate to zero growth rate and nitrogen limiting conditions to phosphorus limiting conditions. Therefore, definition of a limiting nutrient based on estimates of nutrient composition in water or on estimates of nutrient composition in the cells is not feasible. Actual definition of those factors responsible for controlling algal blooms in a specific body of water requires considerable study of all the factors which can govern growth of algal population: light, temperature, macronutrients and micronutrients, mixing, predation, settling and resuspension, and the diurnal and seasonal variation in those factors.

\section{Role of Carbon in Eutrophication Processes}

Kuentzel (1969), in attempting to demonstrate the general lack of inorganic carbon in natural waters, quotes Hutchinson (1957) as saying that the free carbon dioxide content of a natural water in equilibrium with atmospheric $\mathrm{CO}_{2}$ will normally be between 0.4 and $1.0 \mathrm{mg} / \mathrm{l}$. While this statement is true, it already has been pointed out that many natural waters are supersaturated with $\mathrm{CO}_{2}$ as evidenced by their low $\mathrm{pH}$ values relative to their total alkalinities. As an example, $\mathrm{pH}$ and alkalinity values for a variety of lakes throughout North America are listed in Table 7. 
Table 4. Critical nutrient concentrations of various waters. ${ }^{a}$

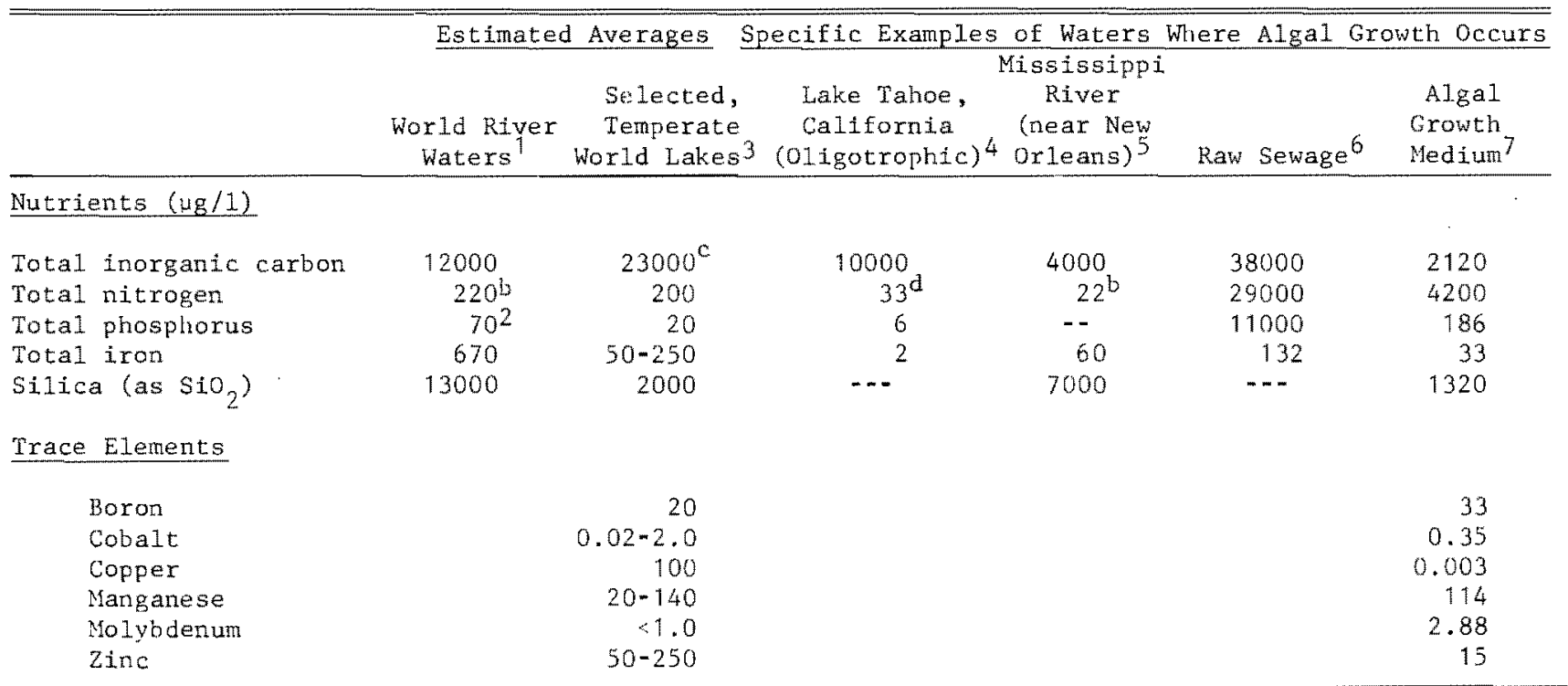

Numbers in parentheses dictate sources of Information from which the estinates were extracted: 1$)$ Benoit, R. J. (1969), 2) Clarke, F.J. (1924), 3) Hutchinson G.E. (1957), 4) McGauhey et a1., 1970b, 4) Hem, 3.D. (1970) 6) McGauhey, 2.H. et a1., 1969, 7) Algal Assay Procedures, EPA, 1971.

Nitrate - N only

c Average of values presented in Table 7 .

d Inorgantc nitrogen only 
Table 5. Chemical composition of some algae from ponds and lakes in southeastern United States. ${ }^{1}$

\begin{tabular}{|c|c|c|c|c|c|c|c|c|}
\hline Analysis & Chara & Pithophora & Spirogyra & $\begin{array}{c}\text { Giant } \\
\text { Spirogyra }\end{array}$ & $\begin{array}{l}\text { Rhizo- } \\
\text { clonium }\end{array}$ & $\begin{array}{l}\text { Oedo- } \\
\text { gonium }\end{array}$ & Mougeotis & Anabaena \\
\hline Ash percent & 43.4 & 27.77 & 13.06 & 13.86 & 17.36 & 12.69 & 14.54 & 5.19 \\
\hline C percent & 29.3 & 35.38 & 42.40 & 41.16 & 39.10 & 40.84 & 40.74 & 49.70 \\
\hline N percent & 2.46 & 2.57 & 3.01 & 2.35 & 3.46 & 2.64 & 1.77 & 9.43 \\
\hline$P$ percent & 0.25 & 0.30 & 0.20 & 0.23 & 0.43 & 0.08 & 0.25 & 0.77 \\
\hline S percent & 0.55 & 1.42 & 0.27 & 0.24 & 0.27 & 0.15 & 0.36 & 0.53 \\
\hline $\mathrm{Ca}$ percent & 8.03 & 3.82 & 0.57 & 0.84 & 0.52 & 0.44 & 1.68 & 0.36 \\
\hline Mg percent & 0.92 & 0.20 & 0.45 & 0.30 & 0.21 & 0.16 & 0.57 & 0.42 \\
\hline $\mathrm{K}$ percent & 2.35 & 3.06 & 0.92 & 0.99 & 1.90 & 3.03 & 1.20 & 1.20 \\
\hline $\mathrm{Na}$ percent & 0.13 & 0.07 & 1.42 & 1.43 & 0.09 & 0.06 & 0.49 & 0.18 \\
\hline Fe mg/l & 2,520 & 2,836 & 1,368 & 1,793 & 1,820 & 1,645 & 60 & 80 \\
\hline $\mathrm{Mn} \mathrm{mg} / \mathrm{I}$ & 2,926 & 829 & 1,641 & 1,658 & 1,687 & 1,729 & 1,080 & 800 \\
\hline $\mathrm{zn} \mathrm{mg} / \mathrm{l}$ & 89 & 29 & 72 & 46 & 89 & 119 & 520 & - \\
\hline $\mathrm{Cu} \mathrm{mg} / \mathrm{I}$ & 19 & 23 & 47 & 34 & 75 & 75 & 143 & 70 \\
\hline B mg/1 & 6.7 & 65 & 4.2 & 4.3 & 1.8 & 8.1 & 8 & $=-$ \\
\hline Analysis & Cladophora & Euglena & Hydrodictyo & $\begin{array}{l}\text { Micro- } \\
\text { on }\end{array}$ & Lyngbya & Nitella & $\begin{array}{l}\text { Aphani- } \\
\text { zomenon }\end{array}$ & \\
\hline Ash percent & 23.38 & 4.12 & 17.94 & 6.2 & 17.20 , & 19.11 & 7.21 & \\
\hline C percent & 35.27 & 48.14 & 39.96 & 46.46 & 40.23 & 38.43 & 47.65 & \\
\hline N percent & 2.30 & 5.14 & 3.87 & 8.08 & 5.01 & 2.70 & 8.57 & \\
\hline$P$ percent & 0.56 & 0.67 & 0.24 & 0.68 & 0.31 & 0.23 & 1.17 & \\
\hline S percent & 1.58 & 0.19 & 1.41 & 0.27 & 0.28 & 0.34 & 1.18 & \\
\hline $\mathrm{Ca}$ percent & 1.69 & 0.05 & 0.69 & 0.53 & 0.45 & 1.89 & 0.73 & \\
\hline Mg percent & 0.23 & 0.07 & 0.17 & 0.17 & 0.14 & 0.95 & 0.21 & \\
\hline $\mathrm{K}$ percent & 6.08 & 0.34 & 4.21 & 0.79 & 0.42 & 3.73 & 0.68 & \\
\hline $\mathrm{Na}$ percent & 0.18 & 9.02 & 0.38 & 0.04 & 0.06 & 0.28 & 0.19 & \\
\hline Mn $\mathrm{mg} / 1$ & 1,040 & 240 & 1,373 & 2,751 & 5,230 & 2,388 & 167 & \\
\hline $\mathrm{Fe} \mathrm{mg} / 1$ & 2,300 & 1,545 & 1,963 & 322 & 3,866 & 2,180 & 833 & \\
\hline $\mathrm{Zn} \operatorname{mg} / 1$ & 10 & 73 & 129 & 48 & 171 & 240 & 120 & \\
\hline $\mathrm{Cu} \mathrm{mg} / 1$ & 190 & 290 & 114 & 37 & 101 & 39 & 187 & \\
\hline $\mathrm{B} \mathrm{mg} / 1$ & 84.6 & 3.8 & $\ldots$ & 3.6 & 112 & 9.8 & -- & \\
\hline
\end{tabular}

1 Taken from Water Quality Criteria (1968), from data supplied by Lawrence (personal communiciation) to the Department of the Interior.

Also indicated in this table is 1 ) whether the lake is supersaturated with carbon dioxide and 2) the current lake condition. The data in this table suggest that there is little correlation between free $\mathrm{CO}_{2}$ availability and degree of eutrophication in these lakes. For the Great Lakes there is almost an inverse relationship between free $\mathrm{CO}_{2}$ available and degree of eutrophication. Similarly, a study of 12 lakes in Northern Saskatchewan by Rawson (1960) failed to show any correlation between free $\mathrm{CO}_{2}$ availability and degree of eutrophication. It appears that many oliogotrophic lakes are relatively rich in available inorganic carbon and that some factor other than carbon is limiting algal growth in these lakes. Lake Tahoe, on the California- Nevada border, is a good example of this situation. This lake is one of the most beautiful natural lakes in the world. Noted for its exceptional clarity, it is considered to be oliogotrophic. It has a total alkalinity of $41^{\circ} \mathrm{mg} / \mathrm{l}$ as $\mathrm{CaCO}_{3}$ and a surface $\mathrm{pH}$ of $7.8^{\prime}$ (McGauhey et al., 1968, 1969). Thus, it contains about $1.4 \mathrm{mg} / \mathrm{l}$ of free $\mathrm{CO}_{2}$ in solution and has a total inorganic carbon content of about $10.2 \mathrm{mg} / \mathrm{l}$. If carbon were indeed the growth-limiting factor in Lake Tahoe, and assuming that (1) all of this carbon were available for algal growth, and (2) 50 percent of the dry weight of the algae is carbon, then Lake Tahoe could support a growth of over $20 \mathrm{mg} / \mathrm{l}$ of algae. This concentration of biomass would easily be described as a serious nuisance condition. Lake Tahoe, although perhaps experiencing some enrichment, is still one of the lesser productive natural water bodies in the world. 
Table 6. Ranges of concentrations of minor chemical constituents in Chlorella pyrenoidosa cells. (After Coree (1970).)

\begin{tabular}{|c|c|c|}
\hline Constituent & $\begin{array}{l}\text { (\% of Total Dry Weight) } \\
\text { Concentration Range }\end{array}$ & Reference \\
\hline Total Ash & $1.4-20.2$ & $\begin{array}{l}\text { [Scott (1943), Spoehr and Milner } \\
(1949), \text { Ketchum and Redfield (1949)] }\end{array}$ \\
\hline $\mathbf{P}$ & $0.06-3.0$ & $\begin{array}{l}\text { [Jewe11 and Mccarty }(1968) \text {, Scott } \\
(1943), \text { Ketchum and Redfleld (1949), } \\
\text { Knauss and Porter (1954), Foree and } \\
\text { McCarty (1968), Borchardt and Agad (1968)] }\end{array}$ \\
\hline $\mathrm{Ca}$ & $0.0=1.6$ & [Scott (1943), Knauss and Porter (1954)] \\
\hline $\mathrm{Mg}$ & $0.3-1.5$ & {$[\operatorname{scote}(1943)]$} \\
\hline $\mathrm{K}$ & $0.04=1.4$ & {$[S \operatorname{cott}(1943)]$} \\
\hline $\mathrm{Na}$ & $0.07-0.7$ & {$[S \operatorname{cott}(1943)]$} \\
\hline s & $0.4-0.8$ & [Knauss and Porter (1954)] \\
\hline $\mathrm{Fe}$ & $0.02=3.4$ & [Knauss and Porter (1954)] \\
\hline Mn & $0.02-2.6$ & [Knauss and Porter (1954)] \\
\hline sr & $0.0004-0.05$ & [Knauss and Porter (1954)] \\
\hline $\mathrm{Cu}$ & $0.0008-0.03$ & [Knauss and Porter (1954)] \\
\hline $2 n$ & $0.0004-0.009$ & [Knauss and Porter (1954)] \\
\hline
\end{tabular}

Edmondson (1970) has presented the chemical and biological changes that occurred when secondary effluent was diverted from Lake Washington producing major changes in nutrient input. Approximately three years following the diversions, the lake has improved markedly as evidenced by the reduction in chlorophyll in surface phytoplankton and transparency of the lake. The summer mean of the chlorophyll content of the phytoplankton in the epilimnion was definitely related to the concentration of phosphate in the surface water during the previous winter but not to nitrate, $\mathrm{CO}_{2}$ or alkalinity. The $\mathrm{CO}_{2}$ and nitrate concentrations decreasea much less than the phosphate after the diversions. The free $\mathrm{CO}_{2}$ concentrations fluctuated around 75 percent of the values present prior to diversion. and the alkalinity increased by about 20 percent after diversions. Based upon this information, it appears to be unlikely that changes in inorganic or organic carbon concentrations contributed to the improvements in Lake Washington.

Similar results on the benefits of diversion have been reported by Liebmann (1970) and Laurent et al. (1970) for several European lakes.

Kerr et al. (1970) have reported that $\mathrm{CO}_{2}$ is the limiting nutrient in the natural waters they studied. This conclusion was supported primarily by laboratory data with samples containing surpluses $(1-2 \mathrm{mg} / \mathrm{l})$ of phosphate and limited quantities of 
Table 7. Alkalinity and $\mathrm{pH}$ data for various natural water bodies in North America.

\begin{tabular}{|c|c|c|c|c|c|c|c|}
\hline Water Body & $\begin{array}{r}\text { Total } \\
\text { A1kalin1 } \\
\text { mg/1 as C }\end{array}$ & $\begin{array}{l}\text { Actual } \\
\mathrm{CO}_{3} \mathrm{pH}\end{array}$ & $\begin{array}{c}\text { Equilibrium } \\
\mathrm{pH}^{\circ} \\
\left(920^{\circ} \mathrm{C}\right.\end{array}$ & $\begin{array}{l}\text { Free } \\
\mathrm{CO}_{2} \\
\mathrm{e}_{2} 0^{\circ} \mathrm{C}\end{array}$ & $\begin{array}{l}\text { Total } \\
\text { Inorgante } \\
\text { Carbon } \\
\mathrm{mg} / 1\end{array}$ & $\begin{array}{l}\text { Reported } \\
\text { Condition of } \\
\text { Water Body }\end{array}$ & Reference \\
\hline \multicolumn{8}{|l|}{ Great Lakes } \\
\hline Erfe & 97 & 8.1 & 8.60 & 1.64 & 24.3 & Eutrophic & \multirow{5}{*}{ Benoit (1969) } \\
\hline Ontario & 96 & 8.1 & 8.60 & 1.63 & 25.0 & Eutrophic & \\
\hline Michigan & 113 & 8.0 & 8.65 & 2.39 & 27.1 & \multirow{3}{*}{$\begin{array}{l}\text { Generally } \\
\text { oligotrophic }\end{array}$} & \\
\hline Huron & 82 & 8.1 & 8.51 & 1.39 & 19.7 & & \\
\hline Superior & 46 & 7.4 & 8.27 & 3.88 & 12.0 & & \\
\hline Lake Tahoe, Callf. & 41 & 7.8 & 8.24 & 1.38 & 10.2 & Oligotrophle & \multirow{4}{*}{$\begin{array}{l}\text { McGauhey et a1. (1968) } \\
\text { Provasoll (1969) } \\
\text { Oglesby (1969) }\end{array}$} \\
\hline Goose Lake, Wis. & 107 & 7.9 & 8.63 & 2.65 & 26.8 & oligotrophic & \\
\hline Sylvan Lake, Wis. & 110 & 9.1 & 8.64 & 0.17 & 26.4 & Hypereutrophic & \\
\hline Green Lake, Wash. & 32.6 & 7.7 & 8.17 & 1.29 & 8.2 & Eutrophic & \\
\hline \multirow{6}{*}{$\begin{array}{l}\text { Canadian Lakes } \\
\text { Cree Lake } \\
\text { LaRonge Lake } \\
\text { Waskesiu Lake } \\
\text { Hunter Bay Lake } \\
\text { B1g Peter Pond }\end{array}$} & & & & & & \multirow{6}{*}{$\left.\begin{array}{l}\text { Oligotrophlc } \\
\text { Mesotrophic } \\
\text { Eutrophic } \\
\text { Oligotrophic- } \\
\text { Mesotrophic } \\
\text { Eutrophic }\end{array}\right\}$} & \multirow{6}{*}{ Rawson (1960) } \\
\hline & $48_{5}^{5}$ & 7.2 & 8.27 & 6.02 & 13.4 & & \\
\hline & $122_{5}^{3}$ & $8.2-7.7^{\circ}$ & 8.69 & $1.63-5.18$ & $29.3-30.5$ & & \\
\hline & $154 \frac{5}{5}$ & $8.2-7.7^{6}$ & 8.78 & $2.06-6.53$ & $37.0-38.5$ & & \\
\hline & $97^{3}$ & $7.9-7.5^{\circ}$ & 8.60 & $2.59-6.49$ & $24.3-25.2$ & & \\
\hline & $113^{5}$ & $8.2-7.2^{6}$ & 8.65 & $1.51-14.2$ & $27.1-31.6$ & & \\
\hline
\end{tabular}

1 Data from reference cited

2 Calculated from Equation 11

3 Calculated from Equation 13

4 Calculated using Saunders et al. (1962) method based on pH and total alkalintty

5 Based upon Rawson's (1960) assumption that 85 percent of the total dissolved solids was bicarbonate 
$\mathrm{CO}_{2}$. Based upon the concentrations of phosphates used, it should have been obvious that $\mathrm{CO}_{2}$ would become limiting. This has been demonstrated many times in wastewater stabilization ponds where carbon is known to limit the total production of algae. Also other possible limiting nutrients (for example, iron and trace elements) were not evaluated, nor was the effect of reducing phosphorus concentrations considered. Edmondson's (1970) results on Lake Washington indicate that reductions in phosphate inputs have'a dramatic effect on the primary productivity of a natural lake with similar geochemical properties. (See Oglesby, 1968.)

In view of the above studies, it can be concluded that carbon limits productivity only under certain well defined conditions that occur relatively infrequently in nature.

\section{SUMMARY}

Algae can obtain carbon for the synthesis of new cells from a variety of sources: inorganic $\left(\mathrm{CO}_{2}, \mathrm{HCO}_{3}{ }^{\circ}, \mathrm{CO}_{3}=\right.$ ) and organic (bacterial degradation, direct utilization). The availability of carbon from these sources depends on the chemistry $(\mathrm{pH}$, buffering capacity, activity of the different ions, ionic composition) and the biology of the aquatic systems (organisms present and nutrient composition). These factors may have as much effect on the kinds of algae present, i.e., succession, as on the mass of algae. The role of rates of growth in relation to rates of nutrient utilization and relationships between growth parameters obtained from such rate studies in natural or semi-natural environments may eliminate some of the confusion which exists concerning which nutrient (carbon, nitrogen, phosphorus, etc.) is limiting. The -role of $\mathrm{CaCO}_{3}$ in waters saturated with $\mathrm{Ca}{ }^{++}$and $\mathrm{CO}_{3}{ }$ ions and those rate-governing factors which might affect the rate of carbon uptake (e.g., temperature, carbonic anhydrase) are still unclear but may not materially affect the mass concentration of natural algal populations.

It is possible that carbon could be growth rate limiting and possibly controlling the algal mass in systems where other nutrients are considerably in excess (relatively short residence time, sewage lagoons; lakes which are already eutrophic; laboratory flask studies with artificial media) or in special situations such as very low alkalinity lakes or extremely hard water lakes. However, in most oligotrophic and mesotrophic waters and in many eutrophic lakes the carbon supply from inorganic sources in the water, from the daily increment from the atmosphere, bacterial degradation of autochthonous and allochthonous materials, would be more than adequate to force some other factor to be limiting (light, nitrogen, phosphorus, etc.). To gain practical perspective on the carbon question, one might ask which factor one would try to control (hence force to be limiting) in order to prevent, reverse, or check the effects of eutrophication. Light, temperature, and carbon would not be among the answers and in terms of practical technology, one would almost have to answer that it would be necessary to control phosphorus. 


\section{REFERENCES CITED}

Abelson, P. 1970. Excessive emotion about detergents. Science, 169, 1033.

Algal Assay Procedures: Bottle Test. 1971. Water Quality Office, Environmental Protection Agency. Corvallis, Oregon. In Preparation.

Algeus, S. 1946. Untersuchungen uber die ernahrunasphysiologic der chlorophyceen. Botan. Notisir, p. 129-278.

Allen, M. B. 1955. General features of algal growth in sewage oxidation ponds. Publ. No. 13. State Water Poll. Contr. Board, State of California, Sacramento, California. $47 \mathrm{p}$.

American Public Health Association. 1965. Standard methods for the examination of water and wastewater. 12th Edition. New York. 769 p.

Annual report of the laboratory of experimental algology and department of applied algology for the year, 1966. 1967. Czech. Acad. Sci., Instit. Microbiol., Trebon, Czech. 138 p.

Annual report of the laboratory of experimental algology and department of applied algology for the year, 1967. 1968. Czech. Acad. Sci., Instit. Microbiol., Trebon, Czech. 174 p.

Barker, H. A. 1935. The metabolism of the colorless alga, Prototheca zopfii Kruger. J. Cell. Comp. Physiol., 7, 73-93.

Bavendamm, W. 1924. Die farblosen und roten schwefelbakterien des sussund salzwassers. Fisher, Jena. $156 \mathrm{p}$.

Beck, L. A., Oswald, W. J., and Goldman, J, C. 1969. Nitrate removal from agricultural tile drainage by photosynthetic systems. Presented before American Society of Civil Engineers, Second National Symposium on Sanitary Engineering Research, Development, and Design, Comell University, Ithaca, New York, July 15, 1969.

Benoit, R. J. 1969. Geochemistry of eutrophication. In eutrophication: causes, consequences, correctives. Proceedings of a Symposium, National Academy of Sciences, Washington, D.C. p. 614-630.

Berger, R, and Libby, W. F. 1969. Equilibration of atmospheric carbon dioxide with sea water: possible enzymatic control of the rate. Science, 164, 1395-1397.

Bemer, R. A. 1965. Activity coefficients of bicarbonate, carbonate, and calcium ions in sea water. Geochim. Cosmochim. Acta 29, 947-965.

Berner, R. A., Scott, M. R., and Thomlinson, C. 1970. Carbonate alkalinity in the pore waters of anoxic marine sediments. Limnol. Oceanogr., 15, 544-549.

Bogan, R. H. 1961. The use of algae in removing nutrients from domestic sewage. In Trans., Seminar on Algae and Metropolitan Wastes. p. 140-147. U.S. Dept. Health Ed. Wel., Publ. Health Serv., SEC TR W61-3.162 p. 


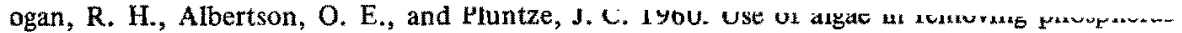
from sewage. J. Sanit. Engr. Div., Am. Soc. Civ. Engrs, 86, SA5, 1-20.

orchardt, J. A. and Azad, H. S. 1968. Biological extraction of nutrients. J. Wat. Pollut. Control Fed., 40, 1739-1754.

ostrom, K. 1967. Some pH-controlling redox reactions in natural waters. In Equilibrium Concepts in Natural Water Systems. p. 286-311. Adv. in Chem. Ser. 67, Am. Chem. Soc., Washington, D.C.

lowen, D. H. M. 1970. The great phosphorus controversy, Envir. Sci. \& Technol., 4, 725-726.

Iricker, O. P. and Garrels, R. M. 1967. Mineralogic factors in natural water equilibria. In Principles and Applications of Water Chemistry. Ed. by Faust, S. D. and Hunter, J. V. p. 449-469. John Wiley \& Sons, Inc,, New York. 643 p.

3riggs, G. E. 1959. Bicarbonate ions as a source of carbon dioxide for photosynthesis. J. Exp. Bot. 10, 90-92.

3riggs, G. E. and Whittingham, C. P. 1952. Factors affecting the rate of photosynthesis of Chorella at low concentrations of carbon dioxide and high illumination. New Phytol. 51, 236-249.

3rinkman, R., Margaria, R., and Roughton, F. J. W. 1933. The kinetics of the carbon dioxidecarbonic acid reaction. Phil. Irans. Roy. Soc. London, A 232, 65-97.

Bristol-Roach, B. M. 1926. On the relation of certain soil algae to some soluble carbon compounds. Ann. Botany 40, 149-201.

Bristol-Roach, B. Af 1927. On the carbon nutrition of some algae isolated from soil. Ann. Botany $41,509-517$.

Brown, R. 1969. Unpublished data. Interagency Nitrogen Removal Group, Fïrebaugh, California.

Brown, R. and Arthur, J. 1969. Effect of surface/volume relationship, $\mathrm{CO}_{2}$ addition, aeration and mixing on nitrate utilization by Scenedesmus cultures in subsurface agricultural waste waters. In Proc., Eutrophication-Biostimulation Assessment Workshop. p. 80-97. SERL, University of California, Berkeley, and Fed. Water Poll. Control Admin., Pac. Northwest Water Lab., Corvallis, Oregon. 281 p.

Bush, A. F., Isherwood, J. D., and Rodgi, S. 1961. Dissolved solids removal from waste water by algae. J. Sanit. Engr. Div., Am. Soc. Civ. Engrs., 87, SA 3, 39-57

Chave, K. E. 1965. Carbonates: association with organic matter in surface seawater. Science, 148, 1723-1724.

Chave, K. E. and Suess, E. 1967. Suspended minerals in seawater. Trans. N. Y. Acad. Sci. 2, 29, $991-1000$.

Chave, K. E. and Suess, E. 1970. Calcium carbonate saturation in seawater: effects of dissolved otganic matter. Limnol. Oceanogr., 15, 633-637.

Clarke, F. W. 1924. The data of geochemistry. 5 th Ed., Bull. U.S. Geol. Sur. $770 \mathrm{p}$.

Cramer, M. and Myers, J. 1948. Nitrate reduction and assimilation in Chlorella pyrenoidosa. J. Gen. Physiol. 32, 93-102. 


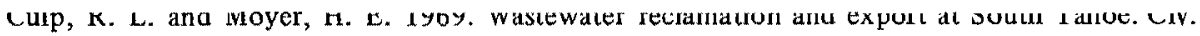
Engr. 39, 6, 38-42.

Davis, E. A., Dedrick, J., French, C. S., Milner, H. W., Myers, J., Smith, J. H. C., and Spoehr, H. A. 1953. Laboratory experiments on Chlorella culture at the Carnegie Institution of Washington, Department of Plant Biology, p. 105-153. In Algal Culture from Laboratory to Pilot Plant, (ed. by Burlew, J. S.) Carnegie Institution of Washington Pubi. 600, Washington, D.C. 357 p.

Dawson, W. L. (chairman) 1970. Phosphates in detergents and the eutrophication of America's waters. Twenty Third Report by the Committee on Government Operations, $91 \mathrm{St}$. Congress, 2nd Session, House Report No. 91-1004, U. S. Government Printing Office, Washing. ton, D.C.

Deuser, W. G. 1970. Isotopic evidence for diminishing supply of available carbon during diatom bloom in the Black Sea. Nature, 225, 1069-1071.

Dietrich, G. 1963. General oceanography. Interscience, New York. 588 p.

Doyle, W. L. 1943. The nutrition of the protozoa. Biol. Revs. Cambridge Phil. Soc., 18, 119-136.

Dye, J. F. 1952. Calculation of the effect of temperature on $\mathrm{pH}$, free carbon dioxide and the . three forms of alkalinity, J. Am. Wat. Wks. Assoc. 44, 356-372.

Eberly, W. R. 1967. Problems in the laboratory culture of planktonic blue-green algae. In Environmental Requirements of Blue-Green Algae, Proc. p. 7-34. U.S. Dept. Int., Fed. Water Poll. Contr. Admin., Corvallis, Oregon. 111 p.

Edmondson, W. T. 1970. Phosphorus, nitrogen, and algae in Lake Washington after diversion of sewage. Science, 169, 690-691.

Edmondson, W. T., Anderson, G. C., and Peterson, D. R. 1956. Artificial eutrophication of Lake Washington. Limnol. Oceanogr., 1, 47-53.

Edsall, J. T. and Wyman, J. 1958. Biophysical chemistry, Vol. 1. Academic Press, Inc. New York. $699 \mathrm{p}$.

Environmental Science and Technology. 1970. Detergent phosphates under fire. 4, 101-102.

Emerson, R. and Green, L. 1938. Effect of hydrogen-ion concentration on Chlorella photosynthesis. Pl. Physiol., 13, 157-168.

Eyster, C. 1958. Bioassay of water from a concretion-forming Marl Lake. Limnol. Oceanogr, 3 , 455-458.

Faurholt, C. 1925. Etudes sur les solutions aqueuses de carbamates et de carbonates. J. Chem. Phys., 22, 1-44.

Felfoldy, L. I. M. 1960a. The role of age and training in carbonate assimilation of unicellular algae. Acta. Biol. Hung, 11, 175-185.

Felfoldy, L. J. M. 1960b. Experiments on the carbonate assimilation of some unicellular algae by Ruttner's conductometric method. Acta. Biol. Hung., 11, 67-75. 
Fitzgerald, G. P. 1961. Stripping effluents of nutrients by bological means. in 1 rans. sermua on Algae and Metropolitan Wastes. p. 136-139. U.S. Dept. Health Ed. Wel., Publ. Health Serv. SEC TR W61-3. $162 \mathrm{p}$.

Fitzgerald, G. P. and Rohlich, G. A. 1962. Biological removal of nutrients from treated sewage: laboratory experiments. Verh. Internat. Verein. Limnol. XV, 597-608.

Fogg, G. E. 1953. The metabolism of algae. John Wiley \& Sons, Inc., New York. 149 p.

Fogg, G. E. 1959. Nitrogen nutrition and metabolic patterns in algae. Symp. Soc. Exp. Biol., 13, $106-125$.

Fogg, G. E. 1965. Algal cultures and phytophankton ecology. University of Wisconsin Press, Madison and Milwaukee. $126 \mathrm{p}$.

Fogg, G. E., Nalewajko, C., and Watt, W. D. 1965. Extracellular products of phytoplankton photosynthesis. Proc. R. Soc. B, 162, 517-534.

Fogg, G. E. and Than-Tun 1960. Interrelations of photosynthesis and assimilation of elementary nitrogen in a blue-green alga. Proc. R. Soc. B., 153, 111-127.

Foree, E. G., and McCarty, P. L. 1968. The decomposition of algae in anaerobic waters. Technical Report No. 95, Department of Civil Engineering, Stanford University, Stanford, California.

Foree, E. G. and Tapp, J. S. 1970. Algal growth and decomposition: effects on water quality, nutrient uptake and chemical composition of algae in batch culture. University of Kentucky Water Resources Institute, Lexington, Kentucky.

Forsberg, C. 1965. Environmental conditions of Swedish charophytes. Symb. Bot. Upsal. 18, $1-67$.

Forster, R. E. and Edsall, J. T. 1969. Carbon dioxide: chemical, biological, and physiological aspects. Science, $166,410-411$.

Galloway, R. A. and Krauss, R. W. 1961. The effect of $\mathrm{CO}_{2}$ on pH in culture media for algae. Pl. Cell Physiol., 2, 331-337.

Garrels, R. M. 1965. Silica: role in buffering of natural waters. Science, 148, 69.

Gates, W. E. and Borchardt, J. A. 1964. Nitrogen and phosphorus extraction from domestic wastewater treatment plant effluents by controlled algal culture. J. Wat. Pollut. Control Fed., 36, 443-462.

Genovese, S. 1963. The distribution of $\mathrm{H}_{2} \mathrm{~S}$ in the Lake of Faro (Messina) with particular regard to the presence of "Red Water." In Marine Microbiology. p. 194-204. (ed. by Oppenheimer, C. H.) Charles C. Thomas, springfield, Illinois. $769 \mathrm{p}$.

Gerloff, G. C., Fitzgerald, G. P., and Skoog, R. 1952. The mineral nutrition of Microcystis aeruginosa. Am. J. Bot., 39, 26-32.

Goldman, C. R. 1960. Primary productivity and limiting factors in three lakes of the Alaska Peninsula. Ecol. Monogr., 30, 207-230.

Goldman, C. R. (ed.) 1965. Primary productivity in aquatic environments. Mem. Ist. Ital. Idiobiol., Suppl. 18, University of California Press, Berkeley, California. 464 p. 
Goldman, C. R. and Armstrong, R. 1969. I. Productivity. Primary productivity studies in Lake Tahoe, California. Vech. Internat. Verein. Limnol., 17, 49-71.

Golueke, C. G., Oswald, W. J., and Gee, H. K. 1962. Increasing high-rate pond loading by phase isolation. Final Report. SERL, University of California, Berkeley, Calif. A pril.

Good, N. E., Winget, G. D., Winter, W., Connolly, T. N. Izawa, S., and Singh, R. M. M. 1966. Hydrogen ion buffers for biological research. Biochem., 5, 467477 .

Greenfield, L. J. 1963. Metabolism and concentration of calcium and magnesium and precipitation of calcium carbonate by a marine bacterium. Ann. N. Y. Acad. Sci., 109, 23,45.

Harned, H. S. and Bonner, F. T. 1945. The first ionization constant of carbonic acid from aqueous solutions of sodium chloride. Am. Chem. Soc. J., 67, 1026-1031.

Harned, H. S. and Davis, R. 1943. The ionization constant of carbonic acid in water and the solubility of carbon dioxide in water and aqueous salt solutions from 0 to $50^{\circ}$. Am. Chem. Soc. J., 65, 2030-2037.

Harned, H. S. and Owen, B. B. 1958. The physical chemistry of electroly te solutions. 3rd ed., Reinhold Publ. Co., New York. 803 p.

Harned, H. S. and Scholes, Jr., S. R. 1941. The ionization constant of $\mathrm{HCO}_{3}^{-}$from 0 to 50 degrees. Am. Chem. Soc. J., 63, 1706-1709.

Hasler, A. D. 1947. Eutrophication of lakes by domestic sewage. Ecology, 28, 383-395.

Hem, J. D. 1970. Study and interpretation of the chemical characteristics of natural water. 2nd ed., Geological Survey Water-Supply Paper 1473. U.S. Government Printing Office, Washington, D.C.

Hemens, J. and Mason, H. M. 1968. Sewage nutrient removal by a shallow algal stream. Water Research, 2, 277-287.

Herbert D., Elsworth, R, and Telling, R. C. 1956. The continuous culture of bacteria: a theoretical and experimental study. J. Gen. Microbiol., 14, 601-622.

Holm, H. W. and Vennes, J. W. 1970. Appearance of purple sulfur bacteria in a sewage treatment lagoon. Appl. Microbiol., 19,988-996.

Holm-Hansen, O. 1967. Recent advances in the physiology of blue-green algae. In Environmental Requirements of Blue-Green Algae, Proc. p. 87-96. U.S. Dept. Interior, Fed. Water Poll. Contr. Admin., Corvallis, Oregon. 111 p.

Hood, D. W. and Park K. 1962. Bicarbonate utilization by marine phytoplankton in photosynthesis. Physiologia PL, 15, 273-282.

Horne, R. A. 1969. Marine chemistry. Wiley-Interscience, New York. 568 p.

Hunter, S. H, and L. Provasoli. 1951. Physiology and biochemistry of protozoa. (ed. by Lwoff, A.) Academic Press, Inc., New York. p. 27-128.

Hutchinson, G. D. 1957. A treatise on limmology, Vol. I. John Wiley \& Sons, Inc., New York. $1015 \mathrm{p}$. 
Jackson, D. F. 1964, Ecological factors governing blue-green algae blooms. Proe, 19th IndustriaI Waste Conference, 1964, Purdue University, Lafayette, Indiana. p. 402-419.

Jewell, W. J., and McCarty, P. L. 1968. Aerobic decomposition of algae and nutrient regeneration. Technical Report No. 91, Department of Civil Engineering, Stanford University, Stanford, Calif.

Kaiser, P. 1966a. Contribution a l'etude de l'ecologie des bacteries photosynthetiques. Ann. Inst. Pasteur, 1II, 733-749.

Kaiser, P. 1966b. Ecologie des bacteries photosy nthetiques. Rev. Ecol. Biol. Soc., 3, 459-472.

Keeling, C. D. 1968. Carbon dioxide in surface ocean waters. J. Geophys. Res., 73, 4543-4553.

Kelley, J. J. and Hood, D. W. 1969. Carbon dioxide in the North Pacific Ocean and Bering Sea. Presented at National Fall Meeting, American Geophysical Union, San Francisco, Calif. December $15-18,1969$.

Kem, D. M. 1960. The hydration of carbon dioxide. J. Chem. Ed, 37, 14-23.

Kerr, P. C., Paris, D. F., and Brochway, D. L. 1970. The interrelation of carbon and phosphorus in regulating heterotrophic and autotrophic populations in aquatic ecosystems. Water Poll. Contr. Res. Ser. 16050 FGS 07/70, Fed. Wat. Qual. Admin., Dept. of the Interior.

Ketchum, B. H. 1954. Mineral nutrition of phytoplankton. A. Rev. Pl. Physiol, 5, 55-74.

Ketchum, B. H. and Redfield, A. C. 1949. Some physical and chemical characteristics of algae growth in mass culture. J. Cell. Comp. Physiol., 33, 281-299.

Kiese, M, and Hastings, A. B. 1940. The catalytic hydration of carbon dioxide. J. Biol. Chem., $132,267-292$.

King, D. L. 1971. The role of carbon in eutrophication. J. Wat. Pollut Control Fed., 42:2035-2051.

Kleijn, H. F. W. 1965. Buffer capacity in water chemistry. Int. J, Air Wat. Poll., 9, 401-413.

Klotz, I. M. 1964. Chemical thermodynamics. Revised Ed., Benjamin, Inc., New York. 468 p.

Knauss, H. J. and Porter, J. W. 1954. The adsorption of inorganic ions by Chlorella pyrenoidosa. Pl. Physiol., 29, 229-234.

Kornberg, H. L. 1966. Anaplerotic sequences and their role in metabolism. In Essays in Biochemistry, Vol. 2. (ed. by Campbell, P. N. and Greville, G. D.) p. 1-31, Academic Press, New York. $216 \mathrm{p}$.

Kramer, J. R. 1967. Equilibrium models and composition of the Great Lakes. In Equilibrium Concepts in Natural Water Systems. p. 243- 254. Adv. in Chem. Ser. 67, Am. Chem. Soc., Washington, D.C. 344 p.

Krishnamurty, K. V. 1969. Carbonic anhydrase in seawater: carbonate complexes. Science, 165 , 929.

Kuentzel, L. E. 1969. Bacteria, carbon dioxide, and algal blooms. J. Wat. Pollut. Control Fed., $41,1737-1747$. 
Kuentzel, L. E. 1970. Correction. J. Wat. Pollut. Control Fed., 42, 353.

Kuhl, A. 1968. Phosphate metabolism of green algae. In Algae, Man, and the Environment. (ed. by Jackson, D. F.) Syracuse University Press. p. 37-52.

Lange, W. 1967. Effect of carbohydrates on the symbiotic growth of planktonic blue-green algae - with bacteria. Nature, 215, 1277-1278.

Langelier, W. F. 1946. Effect of temperature on the $\mathrm{pH}$ of natural waters. J. Am. Wat. Wks. Assoc., 38, 179-185.

Laurent, P. J., Garaucher, J., and Vivier, P. 1970. The condition of lakes and ponds in relation to the carrying out of treatment measures. Presented at the 5 th International WaterPollution Research Conference, San Francisco, Calif.

Lee, G. F. and Hoadley, A. W. 1967. Biological activity in relation to the chemical equilibrium composition of natural waters. In Equilibrium Concepts in Natural Water Systems. p. 319-338. Adv. in Chem. Ser. 67, Am. Chem. Soc., Washington, D.C. 344 p.

Legge, R. F. and Dingledein, D. 1970. We hung phosphates without a fair trial. Can. Res. Devel., March, 1970. p. 19-42.

Levshina, N. A. 1965. The influence of $\mathrm{CO}_{2}$ on the development of diatoms. Bull. Mose. Obsehestva Ispytateleiy Prirody, No. Ser. Otd. Biol., 70, 139-140.

Lewin, J. C. 1963. Heterotrophy in marine diatoms. In Symposium on Marine Microbiology. (ed. by Oppenheimer, C. H.) Springfield, Illinois.

Lewin, R. A. (editor) 1962. Physiology and biochemistry of algae. Academic Press, New York.

Liebmann, H. 1970. Biological and chemical investigations on the effect of sewage on the eutrophication of Bavarian Lakes. Presented at the 5 th International Water Pollution Research Conference, San Francisco, Calif.

Likens, G. E. (chairman) 1971. The limiting nutrient controversy. Symposium on nutrients and eutrophication. Amer. Soc. of Limnol. and Oceanogr., Michigan State University, East Lansing, Michigan.

Litchfield, C. D. and Hood, D. W. 1964. Evidence for carbonic anhydrase in marine and freshwater aglae. Verh. Internat. Verein. Limnol., XV, 817-828.

Litchfield, C. D., Colwell, R. R., and Prescott, J. M. 1969. Numerical taxonomy of heterotrophic bacteria growing in association with continuous culture Chlorella sorokiniana, Appl. Microbiol., 18:1044-1049.

Ludwig, H. F., Oswald, W. J., Gotaas, H. B., and Lynch, V. 1951. Algae symbiosis in oxidation ponds I. Growth characteristics of Euglena gracilis cultured in sewage. Sewage Ind. Wastes, $23,1337-1355$.

Mackenthun, K. M., Keup, L. E., and Stewart, R. K. 1968. Nutrients and algae in Lake Sebasticook, Maine. J. Wat. Pollut. Control Fed., 40 (Part 2), R 72-R81.

Mahler, H. R. and Cordes, E. H. 1966. Biological chemistry. Harper \& Row, New York. 872 p.

Mattoni, R. H. 1967. A study of the use of biomass systems in water renovation. Final Report SID 67-401, Space and Information Systems Div., North American Aviation, Inc. 108 p. 
McCarty, P. L. 1970. Phosphorus and nitrogen removal by biological sy stems. Proceedings of the Wastewater Reclamation and Reuse Workshop, University of California, Berkeley, Calif. In Press.

McGauhey, P. H. 1968. Engineering management of water quality. McGraw- Hill Inc., New York. $295 \mathrm{p}$.

McGauhey, P. H., Rohlich, G. A., Pearson, E. A., Porcella, D. B., Middlebrooks, E. J. and Dugan, G. L. 1970a. Eutrophication of surface waters-Indian Creek Reservoir. LTAC, FWQA Progress Report for Grant No. 16010 DNY, South Lake Tahoe, Calif. 141 p.

McGauhey, P. H., Rohlich, G. A., Pearson, E. A., Middlebrooks, E. J., Dugan, G. L., and Porcella, D. B. 1970b. Eutrophication of surface waters-Lake Tahoe: field studies. LTAC, FWQA Progress Report for Grant No. 16010 DSW, South Lake Tahoe, Calif. 109 p.

McGauhey, P. H., Rohlich, G, A., Pearson, E. A., Middlebrooks, E. J., Porcella, D. B., Adinaryana, A., and Tunzi, M. 1969. Eutrophication of surface waters-Lake Tahoe: laboratory and pilot pond studies. LTAC, FWPCA Progress Report for Grant No. WPD 48-01 (R1), South Lake Tahoe, Calif. 180 p.

McGauhey, P. H., Rohlich, G. A., Pearson, E. A. Middlebrooks, E. J., Tunzi, M., and Aleti, A. 1968. Eutrophication of surface waters- Lake Tahoe. FWPCA Progress Report, South Lake Tahoe, Calif. 178 p.

McIntire, C. D. 1969. A laboratory approach to the study of the physiological ecology of benthic algal communities. In Proc. Eutrophication-Biostimulation Assessment Workshop. p. 146-157. SERL, University of California, Berkeley, and Fed. Water Poll. Control Admin., Northwest Water Lab., Corvallis, Oregon. 281 p.

McLachlan, J. 1962. Effects of pH and nitrogen sources on growth of Microcystis aemginosa kutz. Can. J. Microbiol, 8, 1-11.

McLachlan, J. and Gorham, P. R. 1961. Growth of Microcystis aeruginosa kutz in a precipitatefree medium buffered with Tris. Can. J. Microbiol., 7, 869-882.

Meffert, M. A. 1955. Algal culture in sewage. In Trans. Conference on the Use of Solar EnergyPhotochemical Processes, Vol. IV, p. 87-94. Stanford Research Instit., University of Arizona and Assoc. for Applied Solar Energy, Tucson, Arizona. (October 31 - November 1, 1955). $187 \mathrm{p}$.

Meldrum, N. U. and Roughton, F. W. J. 1933. Carbonic anhydrase: its preparation and properties. J. Physiol. (London), 80, 113-142.

Merezhko, O. 1. 1968. Carbon sources during autotrophic nutrition of blue-green algae. In Tsvetenie Vody. p. 187-196. (ed. by Topachevskii, A. V., Izd. "Naukova Dumka," Kiev, U.S.S.R. (in Russian - Chem. Abst. No. 99035r)

Middlebrooks, E. J., Maloney, T. E., Powers, C. F., and Kaack, L. M. (editors) 1969. Proceedings of the eutrophication - biostimulation assessment workshop. University of California, Berkeley, and Fed. Water Poll. Control Admin., Northwest Lab., Corvallis, Oregon. 281 p.

Miller, R. 1968. A solar-illuminated algal photosynthetic exchanger. Publ. No. SAM-TR-68-66. USAF School of Aerospace Medicine, Aerospace Medical Division (AFSC), Brooks Air Force Base, Texas. $19 \mathrm{p}$. 
Milner, H. W. 1953. The chemical composition of algae. In Algal Culture from Laboratory to Pilot Plant. p. 285-302. (ed. by Burlew, J. S.) Camegie Institution of Washington, Publ. 600 , Washington, D.C. $357 \mathrm{p}$.

Monod, J. 1949. The growth of bacterial cultures. A. Rev. Microb., 3:371-394.

Monod, J. 1950. La technique de culture continue, theorie et applications. Ann. Inst. Pastuer, 79, $390-410$.

Morton, S. D. and Lee, G. F. 1968a. Calcium carbonate equilibria in lakes. J. Chem. Ed., 45, $511-513$.

Morton, S. D. and Lee, G. F. 1968b. Calcium carbonate equilibria in oceans - ion pair formation. J. Chem. Ed., 45, 513-515.

Myers, J, 1951. Physiology of the algae. A. Rev. Microbiol., 5, 157-180.

Myers, J. 1953. Growth characteristics of algae in relation to the problem of mass culture. In Algae Culture from Laboratory to Pilot Plant. p. 37-54. Carnegie Institution of Washington, Publ. 600, Washington, D.C. 357 p.

Nelson, E. B., Cenedella, A. and Tolbert, N. E. 1969. Carbonic anhydrase levels in Chlamydomonas. Phytochem., 8, 2305-2306.

Novick, A. and Szilard, L. 1950. Experiments with the chemostat on spontaneous mutations of bacteria. Proc. Nat. Acad. Sci., 36, 708-719.

Odum, H. T. 1956. Primary production of flowing water. Limnol. Oceanogr., 1, 102-117.

Oglesby, R. T. 1968. Effects of controlled nutrient dilution on a eutrophic lake. Proceedings of 4th International Conference on Water Pollution Research. Pergamon Press, Oxford, England.

Oglesby, R. T. 1969. Eutrophication of a lake. In Eutrophication: causes, consequences, correctives. Proceedings of a symposium. National Academy of Sciences, Washington, D.C. p. $483-493$.

Oppenheimer, C. H. 1961. Note on the formation of spherical aragonitic bodies in the presence of bacteria from the Bahama Bank. Geochem. Cosmochim. Acta, 23, 295-296.

Osterlind, S. 1949. Growth conditions of the alga Scenedesmus quadricauda with special reference to the inorganic carbon sources. Symb. Bot. Upsal., 10, No. 3.

Osterlind, S. 1950a. Inorganic carbon sources of green algae I. Growth experiments with Scenedesmus quadricauda and Chlorella pyrenoidosa. Physiologia Pl. 3, 353-360.

Osterlind, S. 1950b. Inorganic carbon sources of green algae II. Carbonic anhydrase in Scenedesmus quadricauda and Chlorella pyrenoidosa. Physiologia Pl. 3.430-434.

Osterlind, S. 1951a. Inorganic carbon sources of green algae III. Measurement of photosynthesis in Scenedesmus quadricauda and Chlorella pyrenoidosa. Physiologia PL, 4,242-254.

Osterlind, S. 1951b. Inorganic carbon sources of green algae IV. Photoactivation of some factor necessary for bicarbonate assimilation. Physiologia PI. 4. 514-527. 
Oswald, W. J. 1963. Light conversion efficiency of algae grown in sewage. Trans. Am. Soc. Civ. Engrs., 128, 47-83.

Oswald, W. J. and Golueke, C. G. 1966. Eutrophication trends in the United States - a problem? J. Wat. Pollut. Control Fed., 38, 964-975.

Oswald, W. J., Gotaas, H. B., Ludwig, H. F., and Lynch, V. 1953a. Algae symbiosis in oxidation ponds II. Growth characteristics of Chlorella pyrenoidosa cultured in sewage. Sewage Ind. Wastes, 25, 26-37.

Oswald, W. J., Gotaas, H. B., Ludwig, H. F., and Lynch, V. 1953b. Algae symbiosis in oxidation ponds III. Photosynthetic oxygenation. Sewage Ind. Wastes, 25, 692-705.

Paasche, E. 1963. The adaptation of the carbon-14 method for the measurement of Coccolith production in Coccolithus huxleyi. Physiologia Pl., 16, 186-200.

Paasche, E. 1964. A tracer study of the inorganic carbon uptake during Coccolith formation and photosynthesis in the Coccolithophorid Coccolithus,huxleyi Physiologia Pl., Supplementum III. Lund.

Park, P. K., Catalfomo, M. Webster, G. R. and Reid, B. H. 1970. Nutrients and carbon dioxide in the Columbia River. Limnol. Oceanogr., 15, 70-79.

Park, P. K., Gordon, L. I., Hager, S. W., and Cissell, M. C. 1969. Carbon dioxide partial pressure in the Columbia River. Science, 166,867-868.

Parsons, T. R., Stephans, K, and Strickland, J. D, H. 1961. On the chemical composition of elevent species of marine phy toplankton. J. Fish. Res. Bd. Can., 18, 1001-1016.

Pearsall, W. H. and Bengry, R. P. 1940. The growth of Chlorella in darkness and in glucose solution. Ann. Bot., 4, 365-377.

Pearson, E. A. Middlebrooks, E. J., Tunzi, M., Aleti, A., McGauhey, P. H., and Rohlich, G. A. 1969. Kinetic Assessment of algal growth. In Proc. of the Eutrophication-Biostimulation Assessment Workshop. p. 56-79. SERL, University of California, Berkeley, and Fed. Water Poll. Cont. Admin. Pacific Northwest Water Lab., Corvallis, Oregon. 281 p.

Pelczar, M. J., Jr. and Reid, R. D. 1965. Microbiology, 2nd Ed., McGraw-Hill Book Co., New York. $662 \mathrm{p}$.

Peterson, M. N. A. 1966. Calcite: rates of dissolution in a vertical profile in the Central Pacific. Science, $154,1542-1544$.

Pfennig, N. 1967. Photosynthetic bacteria. A. Rev. Microbiol., 21, 573-600.

Pipes, W. O. 1962a. Carbon dioxide-limited growth of Chtorella in continuous culture. Appl. Microbiol., 10, 281-288.

Pipes, W. O. $1962 \mathrm{~b}$. $\mathrm{pH}$ variation and BOD removal in stabitization ponds. $J$. Wat. Pollut. Control Fed., 34, 1140-1150.

Pipes, W. O. and Gotaas, H. B. 1960. Utilization of organic matter by Chlorella grown in sewage. Appl. Microbiol, , 8, 163-169.

Pipes, W. O. and Koutsoyannis, S. P. 1962. Light-limited growth of Chlorella in continuous cultures. Appl. Microbiol., 10, 1-5. 
Porcella, D. B. 1969. Continuous-flow (chemostat) assays. In Proc. of the EutrophicationBiostimulation Assessment Workshop. p. 7-22. SERL, University of California, Berkeley and Fed. Water Poll. Contr. Admin., Pacific Northwest Water Lab., Corvallis, Ore. 281 p.

Porcella, D. B., Grau, P., Huang, C. H., Kadimsky, J., Toerien, D. F., and Pearson, E. A. 1970. Provisional algal assay procedures: first annual report of University of Califomia. SERL Report No. 70-8. University of California, Berkeley, Calif. 180 p.

Provasoli, L. 1969. Algal nutrition and eutrophication. In Eutrophication: causes, consequences, correctives. Proceedings of a symposium. National Academy of Sciences, Washington, D.C. p. 574-593.

Provisional Algal Assay Procedures. 1969. Joint Industry-Government Task Force on Eutrophication, P.O. Box 3011, Grand Central Station, New York, New York 10017.62 p.

Rabinowitch, E. I. 1945. Photosynthesis, Vol, I, Chapter 8. Interscience Publishers, Inc., New York. 599 p.

Rabinowitch, E. I. 1951. Photosynthesis, Vol. II, Part 1, Chapter 27, 886. Interscience Publishers, Inc., New York. 591 p.

Rabinowitch, E. I. 1956. Photosynthesis, Vol. II, Part 2, Chapter 37, Part D, 1886. Interscience Publishers, Inc., New York. 878 p.

Rabinowitch, E. and Govindjee. 1969. Photosynthesis. John Wiley \& Sons, Inc., New York. 271 p.

Rawson, D. S. 1960. A limnological comparison of twelve large lakes in northern Saskatchewan. Limnol. Oceanogr., 5, 195-211.

Riepe, M. E. and Wang, J. H. 1967. Elucidation of the catalytic mechanism of carbonic anhydrase. J. Am. Chem. Soc., 89, 4429.

Rohlich, G. A. 1961. Chemical methods for the removal of nitrogen and phosphorus from sewage plant effluents. In Trans. 1960 Seminar on Algae and Metropolitan Wastes. R. A. Taft San. Engr. Center Technical Report W61-3. p. 130-135.

Rohlich, G. A. (chairman) 1969. Eutrophication: causes, consequences, correctives. Proceedings of a symposium. National Academy of Science, Washington, D.C. $661 \mathrm{p}$.

Rosenberg, J. 1954. Use of a glass electrode for measuring rapid changes in photosynthetic rates. J. Gen. Physiol., 37, 753-774.

Rosenberg, J. 1957. On the measurement of carbon dioxide uptake with a glass electrode. J. Gen. Physiol., 40, 827-831.

Rough ton, F. J. W. 1941. The kinetics and rapid thermodynamics of carbonic acid. J. Am. Chem. Soc., 63, 2930-2934.

Saunders, G. W., Trama, F. B., and Bachmann, Z. W. 1962. Evaluation of a modified $\mathrm{C}^{14}$ technique for estimation of photosynthesis in large lakes. Great Lakes Research Division, Institute of Science and Technology, University of Michigan Publ. No. 8.61 p.

Sawyer, C. N. 1954. Factors involved in disposal of sewage effluents to lakes. Sewage Ind. Wastes, $26,317-328$. 
Sawyer, C. N. 1970. Discussion - bacteria, carbon dioxide, and algal blooms. J. Wat. Pollut. Control Fed., 42, 677.

Sawyer, C. N. and McCarty, P. L. 1967. Chemistry for sanitary engineers. 2nd Ed., McGraw Hill, New York. 518 p.

Scheurer, P. G., Brownell, R. M., and LuValle, J. E. 1958. An apparatus for the investigation of rapid reactions. The kinetics of the carbonic acid dehydration. J. Phys. Chem., 62, 809-812.

Schmalz, R. F. and Chave, K. E. 1963. Calcium carbonate: factors affecting saturation in ocean waters off Bermuda. Science, 139, 1206-1207.

Scott, G. T. 1943. The mineral composition of Chlorella pyrenoidosa grown in culture media containing varying concentrations of calcium, magnesium, potassium, and sodium. J. Cell. Comp. Physiol. 21, 327.338.

Semenenko, V. E. 1966. The dependence of growth, productivity and photosynthetic rate in Chlorella upon $\mathrm{CO}$ content in the gas mixture and the rate of aeration in the culture. In Upravlyaemyy Biosintez, Izdatelstwo Nauka, Moscow. p. 128-136.

Setlik, I., Sust, V., and Malek, I. 1966. Dual purpose open circulation units for algal culture I. Institute of Microbiology, CSAV, Praha and Trebon, Czech. $116 \mathrm{p}$.

Shapiro, J. 1970. A statement on phosphorus. J. Wat. Pollut. Control Fed., 42, 772-775.

Siever, R., Beck, K. C., and Berner, R. A. 1965. Composition of interstitial waters of modern sediments. J. Geol., 73, 39-73.

Sillen, L. G. 1961. The physical chemistry of sea water. In Oceanography (ed. by Sears, M.) p. 549-581. Am. Assoc. Adv. Sci., Publ. No. 67, Washington, D.C.

Simkiss, K. 1964. The inhibitory effects of some metabolites on the precipitation of calcium carbonate from artificial and natural sea water. J. Cons. Perm. Int. Explor. Mer., XXIX, 6-18.

Sirs, J. A. 1958. Electrometric stopped flow measurements of rapid reactions in solution. Part I. Conductivity measurements. Trans. Faraday Soc., 54, 201-206.

Skulberg, O. M. 1967. Algal cultures as a means to assess the fertilizing influence of pollution. In Advances in Water Pollution Research, Third International Conference, I, p. 113-138. Water Pollution Control Federation, Washington, D.C. 378 p.

Smith, H. C., Brown, H. E., Moyer, J. E., and Ward, C. H. 1968a. Some excretory products of Chlorella pyrenoidosa. Develop. Indust. Microbiol., 9, 355-361.

Smith, H. C., Brown, H. E., Moyer, J. E., and Ward, C. H. 1968b. Utilization of excretory products of Chlorella pyrenoidosa by selected bacteria. Develop. Indust. Microbiol,, 9, 363-369.

Smith, J. B., Tatsumota, M., and Hood, D. 1960. Carbamino carboxylic acids in photosynthesis. Limnol. Oceanogr., 5, 425- 469.

Soltero, F. V. and Lee, G. F. 1967. Apparatus for automatic pH control in algal cultures. Environ. Sci. \& Technol., 1, 503-505. 
Spoehr, H. A. and Milner, H. W. 1949. The chemical composition of chlorella: effect of environmental conditions. Pl. Physiol. 24, 120-149.

Stanier, R. Y., Doudoroff, M., and Adelberg, E. A. 1970. The microbial world. 3rd Ed, Prentice Hall, Inc., Englewood Cliff, New Jersey. 873 p.

Steemann Nielsen, E. 1951. Passive and active ion transport during photosynthesis in water plants. Physiologia Pl., 4, 189-199.

Steemann Nielsen, E. 1952. Experimental carbon dioxide curves in photosynthesis. Physiologia P1., 5, 145-159.

Steemann Nielsen, E. 1953. Carbon dioxide concentration, respiration during photosynthesis and maximum quantum yield of photosynthesis. Physiologia Pl., 6, 316-332.

Steemann Nielsen, E, 1955a. Carbon dioxide as carbon source and narcotic in photosynthesis and growth of Chlorella pyrenoldosa. Physiologia P1. 8, 317-335.

Steemann Nielsen, E. 1955b. The production of organic matter by the phytoplankton in a Danish lake receiving extraordinarily great amounts of nutrient salts. Hydrobiologia, 7, 68-74.

Steemann Nielsen, E. 1963. On bicarbonate utilization by marine phytoplankton in photosynthesis. With a note on carbamino carboxylic acids as a carbon source. Physiologia Pl., $16,466-469$.

Steemann Nielsen, E. 1966. The uptake of free $\mathrm{CO}_{2}$ and $\mathrm{HCO}_{3}$ during photosynthesis of plankton algae with special reference to the Coccolithophorid Coccolithus huxieyi. Physiologia Pl, 19, 232-240.

Steemann Nielsen, E. and Jensen, P. K. 1958. Concentration of carbon dioxide and rate of photosynthesis in Chlorella pyrenoidosa. Physiologia Pl., 11, 170-180.

Steemann Nielsen, E. and Kristiansen, J. 1949. Carbonic anhydrase in submerged antotrophic plants. Physiologia $\mathrm{Pl}$., 2, 325-331.

Steemann Nielsen, E. and Willemoes, M. 1966. The influence of $\mathrm{CO}$ concentration and pH on two Chlorella species grown in continuous light. Physiologia Pl., 19, 279-293.

Stewart, K. M. and Rohlich, G. A. 1967. Eutrophication - a review. Water Quality Control Board, California, Publ. No. 34, Sacramento, Calif. 188 p.

Stuum, W. 1964. Chemistry of natural waters in relation to water quality. In Symposium, Environmental Measurements. p. 299-323. Publ. No, 999-WP-15, Publ. Health Ser., U.S. Dept. Health Ed, and Wel.

Stumm, W. 1967. Metal ions in aqueous solutions. In Principles and Applications of Water Chemistry. (ed. by Faust, S. D. and Hunter, J. V.) p. 520-560. John Wiley \& Sons, Inc*, New York. 643 p.

Stumm, W. and Leckie, J. O. 1970. Phosphate exchange with sediments: its role in the productivity of surface waters. Presented at 5 th International Water Pollution Research Conference, July-August, 1970. San Francisco, Calif.

Stumm, W. and Morgan, J. J. 1962. Trans. 12th Annual Conf. San. Engr., University of Kansas Press, Lawrence, Kansas. p. 16.

Swift, E. and Taylor, W. R. 1966. The effect of pH on the division rate of the Coccolithophorid Cricosphaera elongata. J. Phycol., 2, 121-125. 
Task Group 2610P Report. 1967. Sources of nitrogen and phosphorus in water supplies. J. Am. Wat. Wks. Assoc., 59, 344-366.

Tew, R. W., Sane, J. O., and Geckler, R. P. 1962. Highly concentrated carbon source for continuous algae cultures. In Biologistics for Space Systems - A Symposium, May 1962, Tech. Documentary Report No. AMRL-TDR-62-116, Oct 1962. Biomedical Laboratory 6570th Aerospace Medical Research Laboratories, Aerospace Medical Division, Air Force Systems Comman, Wright-Patterson Air Force Base, Ohio.

Thomas, E. A. 1955. Sedimentation in oligatrophen und eutrophen seen als ausduick der produktivitat. Verh. Internat. Verein. Limnol., 12, 383-393.

Thomas, J. F. and Trussell, R. R. 1970. The influence of Henry's law on bicarbonate equilibria. $J$. Am. Wat. Wks. Assoc., 62, 185-187.

Toerien, D. F., Huang, C. H., Porcella, D. B., Radimsky, J., and Pearson, E. A. 1970. The role of chemostat assays in eutrophication analysis. AlBS Symposium, Lafayet te, Indiana.

Trelease, S. F, and Trelease, H. M. 1935. Changes in hydrogen-ion concentration of culture solutions containing nitrate and ammonium nitrogen. Am. J. Bot., 22, 520-542.

Vaccaro, R. F. and Jannasch, H. W. 1967. Variations in uptake kinetics for glucose by natural populations in seawater. Limnol. Oceanogr., 12,540-542.

Ward, C. H. and Moyer, J. E. 1966. Ecologic relationships between bacteria and algae in mass culture. In Bioregenerative Systems, NASA SP-165, National Aero. and Space Admin. p. $117-127$.

Ward, C. H., Moyer, J. E., and Vela, G. R. 1964. Studies on Bacteria associated with Chlorella pyrenoidosa TX71105 in mass culture, Develop. Indust. Microbiol., 6, 213-221.

Water Quality Criteria. 1968. Federal Water Pollution Control Administration, Washington, D.C. $234 \mathrm{p}$.

Watt, W. D. and Paasche, E. 1963. An investigation of the conditions for distinguishing between $\mathrm{CO}$ and bicarbonate utilization by algae according to the methods of Hood and Park. Physiologia Pl., 16, 674-681.

Weber, W. J. and Stumm, W. 1963a. Buffer systems of natural fresh waters. J. Chem. Engng. Data, $8,464-468$.

Weber, W. J. and Stumm, W. 1963b. Mechanism of hydrogen ion buffering in natural waters. J. Am. Wat. Wks. Assoc, , 55, 1553-1578.

Weyl, P. K. 1961. The carbonate saturometer, J. Geol., 69, 32-44.

Witt, V. and Borchardt, J. A. 1960. The removal of nitrogen and phosphorus from sewage effluent through the use of algal culture. J. Biochem. Microbiol. Tech. Eng, II, 187-203.

Wright, J. C. 1969. Productivity of rivers. In Proc. of the Eutrophication-Biostimulation Assessment Work shop. p. 186-206. SERL, University of California, Berkeley and Fed. Water Poll. Control Admin., Pacific Northwest Water Lab., Corvallis, Oregon. 281 p.

Wuhrmann, K. 1957. Die dutte reinigungstufe: wege und bisherige erfolge in der eliminierung eutrophierender staffe. Schweiz. Z. Hydrol., 19, 409-427. 